UNIVERSIDADE DE SÃO PAULO

FACULDADE DE ECONOMIA, ADMINISTRAÇÃO E CONTABILIDADE

DEPARTAMENTO DE ADMINISTRAÇÃO

PROGRAMA DE MESTRADO PROFISSIONAL EM EMPREENDEDORISMO

\author{
AMBIENTES E INCENTIVOS FISCAIS PARA INOVAÇÃO - \\ Uma proposta para criação do Núcleo do Parque Tecnológico \\ da Universidade de São Paulo
}

André Luiz Bortolato da Palma

Orientadora: Profa. Dra. Luciane Meneguin Ortega

SÃO PAULO 
Prof. Dr. Marco Antonio Zago

Reitor da Universidade de São Paulo

Prof. Dr. Adalberto Américo Fischmann

Diretor da Faculdade de Economia, Administração e Contabilidade

Prof. Dr. Roberto Sbragia

Chefe do Departamento de Administração

Prof. Dr. Martinho Isnard Ribeiro de Almeida

Coordenador do Programa de Mestrado Profissional em Empreendedorismo 


\section{AMBIENTES E INCENTIVOS FISCAIS PARA INOVAÇÃO \\ Uma proposta para criação do Parque Tecnológico \\ da Universidade de São Paulo}

Dissertação apresentada ao Departamento de Administração da Faculdade de Economia, Administração e Contabilidade da Universidade de São Paulo como requisito para a obtenção do título de Mestre em Adminstração.

Orientadora: Profa. Dra. Luciane Meneguin Ortega

\section{SÃO PAULO}


FICHA CATALOGRÁFICA

Elaborada pela Seção de Processamento Técnico do SBD/FEA/USP

Palma, André Luiz Bortolato da

Ambientes e incentivos fiscais para inovação: uma proposta para

criação do Núcleo do Parque Tecnológico da Universidade de São

Paulo / André Luiz Bortolato da Palma. - São Paulo, 2017.

$121 \mathrm{p}$.

Dissertação (Mestrado) - Universidade de São Paulo, 2017.

Orientador: Luciane Meneguin Ortega.

1. Inovação 2. Incentivo fiscal 3. Cooperação universidade-empresa I. Universidade de São Paulo. Faculdade de Economia, Administração e Contabilidade. II. Título.

CDD -658.4 
Non nóbis, Dómine, non nóbis

Sed nómine tuo da glóriam!

(Ps 113,9) 



\section{AGRADECIMENTOS}

Agradecer é antes de tudo um ato de justiça. Reconhecer o bem que outros fizeram ou suportaram por nossa causa é um dever.

Assim, em primeiro lugar devemos agradecer a Deus, que nos criou à sua imagem e semelhança e que por nosso amor deu-nos seu Filho, "puer natus es nobis”. À Santíssima Virgem Maria, mãe do Verbo de Deus e nossa, "ecce mater tua".

Agradeço também a minha amada família, minha esposa Laura e meus cinco filhos: Stella, Roberto, Olivia, Clara e o pequeno Francisco.

Agradeço de forma especial à minha orientadora Profa. Luciane Meneguin Ortega que tão generosamente conduziu-me à conclusão deste trabalho.

Ao Prof. Vanderlei Bagnato por acreditar e apoiar os esforços despendidos para a concretização do Núcleo do Parque Tecnológico da USP, meu sincero agradecimento.

À toda equipe da AUSPIN, especialmente a Andrea Revoredo e a Ivanei Oliveira.

Ao Professor Dr. Oswaldo Massambani pela persistência e ao Secretário do Ministério da Ciência, Tecnologia e Inovação, Prof. Dr.Álvaro Taubes Prata pelo apoio.

Aos professores do Programa de Mestrado Profissional pela dedicação e amizade.

De forma singular agradeço ao Professor Martinho Isnard Almeida, que possui um coração tão grande que certamente todos seus alunos lá estão. 


\section{RESUMO}

A inovação tecnológica tem sido considerada um fator essencial e decisivo para a boa performance de uma economia e, portanto, foco de profundos debates e estudos ao longo das últimas décadas. No contexto brasileiro, a matéria é relativamente recente quando comparadas com países estrangeiros. Por outro lado, a dinâmica presenciada traz a oportunidade de participar ativamente deste processo de consolidação dos mecanismos de inovação, especialmente aqueles que tratam da interação entre Universidade e Empresa. Neste sentido, desponta-se o questionamento sobre qual o papel dos ambientes especializados como os Parques Tecnológicos dentro do Sistema Nacional de Inovação Brasileiro? Como contribuição prática, a partir da experiência do autor, apresenta-se a proposição de um modelo para criação de um ambiente no qual empresas privadas possam desenvolver programas de inovação colaborativa. Como forma de aplicação prática, tal modelo proposto está sendo utilizado como base na construção do Núcleo Parque Tecnológico da Universidade de São Paulo e encontra-se em estágio avançado de negociações de parcerias e investimentos público-privado. Como contribuição acadêmica, o autor busca identificar e analisar os diversos conceitos sobre ambientes de inovação e mecanismos de incentivo à inovação, especialmente aqueles que dizem respeito ao seu financiamento a fim de amparar a proposição do modelo.

Palavras-chave: inovação, incentivos fiscais, cooperação universidade-empresa, parque tecnológico. 


\begin{abstract}
Technological innovation has been considered an essential and decisive factor for the good performance of an economy and, therefore, the focus of deep debates and studies over the last decades. In the Brazilian context, the matter is relatively recent when compared with foreign countries. On the other hand, the dynamics witnessed the opportunity to participate actively in this process of consolidation of innovation mechanisms, especially those that deal with the interaction between University and Company. In this sense, the question arises as to the role of specialized environments such as Technology Parks within the Brazilian National Innovation System? As a practical contribution, based on the author's experience, a proposal is presented for a model for creating an environment in which private companies can develop collaborative innovation programs. As a practical application, such a proposed model is being used as a basis for the construction of the Technological Park Nucleus of the University of São Paulo and is at an advanced stage of negotiations of public-private partnerships and investments. As an academic contribution, the author seeks to identify and analyze the various concepts about innovation environments and mechanisms to encourage innovation, especially those that concern their financing in order to support the proposition of the model.
\end{abstract}

Keywords: innovation, tax incentives, university-company cooperation. 


\section{SUMÁRIO}

$\begin{array}{ll}\text { Lista de Abreviaturas } & 2\end{array}$

Lista de Tabelas $\quad 3$

Lista de Figuras $\quad 4$

Lista de Gráficos $\quad 5$

$1 \quad$ Introdução $\quad 15$

$\begin{array}{lll}1.1 & \text { Relato da Experiência } & 17\end{array}$

$\begin{array}{lr}1.2 & \text { Situação Problema } \\ 1.3 & 19\end{array}$

\begin{tabular}{ll}
1.3 & Questão de Pesquisa \\
\hline
\end{tabular}

$\begin{array}{llr}1.4 & \text { Objeto da Pesquisa } & 22\end{array}$

$\begin{array}{llr}1.5 & \text { Justificativa } & 23\end{array}$

$2 \quad$ Estrutura do Trabalho $\quad 25$

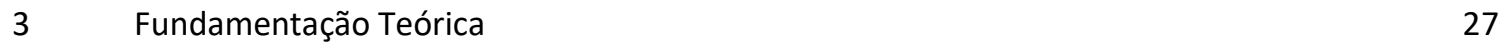

$\begin{array}{lll}3.1 & \text { Taxonomia da Inovação } & 27\end{array}$

3.2 Modelo de Inovação Fechada e o Modelo de Inovação Aberta 30

$\begin{array}{lll}3.3 & \text { Sistemas de Inovação } & 34\end{array}$

$\begin{array}{lll}3.4 & \text { Ambientes de Inovação } & 39\end{array}$

$\begin{array}{lll}3.5 & \text { Financiamento da Inovação } & 45\end{array}$

$\begin{array}{lll}3.5 .1 & \text { A Lei de Informática } & 47\end{array}$

3.5.2 Sobre a Lei de Inovação e Fundamento Legal 50

$\begin{array}{lll}\text { 3.5.3 Sobre a Lei do Bem } & 51\end{array}$

3.5.4 O artigo 19-A da Lei do Bem $\quad 55$

$4 \quad$ Metodologia $\quad 57$

$\begin{array}{lll}4.1 & \text { Processo de Tomada de Decisão } & 58\end{array}$

$\begin{array}{lll}4.2 & \text { Fase I- Formulação } & 60\end{array}$

$\begin{array}{lll}4.3 & \text { Fase II -Execução } & 62\end{array}$

4.3.1 O Ponto de Partida $\quad 63$

4.3.2 Definições de Escopo e Objetivos $\quad 64$

4.3.3 O Vaivém Exploratório $\quad 66$

$\begin{array}{lll}4.4 & \text { O Ponto de Chegada } & 75\end{array}$

$5 \quad$ Análise dos Resultados $\quad 79$

6 Conclusão $\quad 80$

$7 \quad$ Bibliografia $\quad 85$

Anexo I - Oficio Auspin para Sr. Ministro MCTIC 89

Anexo II - Ofício AUSPIN para Sr. Secretário M. Strama 91

Anexo III - Ofício do Magnífico Reitor da USP 94

Anexo IV - Carta de Intenção da Caixa Econômica Federal 95

Anexo V - Proposta de Constituição e Desenvolvimento do NPT 96 


\section{LISTA DE ABREVIATURAS}

ABDI Agência Brasileira Desenvolvimento Industrial

ANPROTEC Ass. Nacional de Entidades Promotaras de Empreendimentos Inovadores

AURP Association of University Research Parks

AUSPIN Agência USP de Inovação

CDT/UnB Univ. de Brasília, Centro de Apoio ao Desenvolvimento Tecnológico

$\mathrm{CNPq} \quad$ Conselho Nacional de Desenvolvimento Científico e Tecnológico

ENCTI Estratégia Nacional de Ciência, Tecnologia e Inovação

IASP International Association of Science Parks

IPEA Instituto de Pesquisa Aplicada

IPEN Instituto de Pesquisas Energéticas e Nucleares

LI Lei da Inovação

LdB Lei do Bem

MCTI Ministério da Ciência Tecnologia e Inovação

NPT Núcleo do Parque Tecnológico

OCDE Organização para Cooperação e Desenvolvimento Econômico

P\&D Pesquisa e Desenvolvimento

PINTEC Pesquisa de Inovação Tecnológica

TAE Teoria de Aprendizagem Experimental

USP Universidade de São Paulo 


\section{LISTA DE TABELAS}

Tabela 1 Fontes de Inovação 28

Tabela 2 Definições de Parques Científicos e Tecnológicos 38

Tabela 3 Regra de investimento em P\&D - Lei de Informática 46

Tabela 4 Utilização da Lei do Bem 47

Tabela 5 Comparação da Renúncia entre os níveis de exclusão 53 


\section{LISTA DE FIGURAS}

$\begin{array}{lll}\text { Figura } 1 \text { O círculo virtuoso da inovação } & 15\end{array}$

Figura 2 Estrutura do Trabalho 25

Figura 3 Taxonomia da Inovação 26

Figura $4 \quad$ O paradigma fechado da gestão de P\&D fechado 29

Figura 5 Paradigma da Inovação Aberta 31

Figura $6 \quad$ O Triângulo de Sábato 33

Figura 7 Modelo da Hélice Tríplice 34

Figura 8 Mapa Teórico do Sistema Brasileiro de Inovação 36

Figura 9 Processo de Pesquisa Básica em Administração 54

Figura $10 \quad$ Framework Metodológico 56 


\section{LISTA DE GRÁFICOS}

$\begin{array}{lll}\text { Gráfico } 1 \text { Crescimento da Produtividade } & 16\end{array}$

Gráfico 2 Evolução dos Parques Tecnológicos no Brasil 21

Gráfico 3 Evolução dos Parques Tecnológicos no Brasil 40

Gráfico 4 Número de Empregados nos Parques Tecnológicos 41

Gráfico 5 Aportes Lei de Informática 45

Gráfico 6 Utilização da Lei do Bem 50 


\section{INTRODUÇÃO}

A geração, a exploração e difusão de um conhecimento ou de uma tecnologia é fundamental para o crescimento não só de uma empresa, mas de toda uma economia (OSLO, 1997). Neste sentido, a performance da inovação torna-se um determinante crucial para o êxito e sucesso deste crescimento.

De acordo com a Terceira edição do Manual de Oslo, a inovação é definida como

"a implementação de um produto (bem ou serviço) novo ou significativamente melhorado, ou um processo, ou novo método de marketing, ou um novo método organizacional nas práticas de negócios, na organização do local de trabalho ou nas relações externas" (pág. 55).

Ao conceber novos produtos/serviços ou por meio da inserção de uma significante mudança tecnológica nos produtos ou serviços já existentes, a empresa cria condições de diferenciação e competitividade que lhe faz perpetuar no tempo (TIDD, 2000).

Esta condição produz um ambiente favorável, produz um verdadeiro círculo virtuoso (CHESBROUGH, 2003). Quanto mais a empresa investe em inovação, mais ela se torna competitiva, aumentam seus horizontes de penetração de mercado, o faturamento cresce, a demanda de empregos também, até mesmo a esfera pública é beneficiada com um recolhimento maior em termos absolutos em tributos. A figura 1 a seguir demonstra $o$ círculo virtuoso da inovação.

\section{Figura 1 - O círculo virtuoso da inovação}

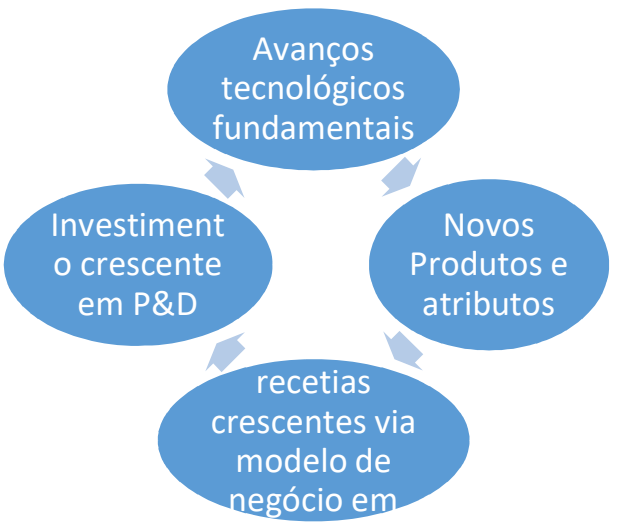

Fonte: Chesbrough (2003, pág. 5) 
Durante estes tempos de crise econômica debelada pelos títulos imobiliários americanos, a Organização para a Cooperação e Desenvolvimento Econômico (OCDE, 2009 -pg. 10) afirma categoricamente que "innovation will be one of the Keys to emerging from the current crisis.". Também o Brasil reconhece esta dinâmica: "Não é por acaso que vários países, a exemplo de Estados Unidos e China, têm colocado a inovação como eixo central de suas estratégias de retomada do crescimento após a crise de 2008”(ENCTI, 2016).

Contudo, a atividade inovativa se desenvolve dentro de um processo cuja natureza é marcada principalmente pela incerteza. Os resultados, dificuldades, riscos tecnológicos, operacionais e mercadológicos não são ainda completamente conhecidos em sua gênese, e também pela complexidade de atores envolvidos.

"Deve-se chamar a atenção para o fato de que as empresas não inovam isoladamente, mas o fazem no contexto de um sistema de redes de relações diretas ou indiretas, a infra-estrutura de pesquisa pública e privada, as insituições de ensito e pesquisa, a economia nacional e internacional, o sistema normativo e um conjunto de outras instituições, sem deixar de lado uma série de políticas governamentais bem direcionadas, estáveis e desburocratizadas" (SBRAGIA et al., 2006 pág. 31).

Neste sentido, o Estado, enquanto ator da inovação, também possui um papel relevante. Como legislador, cabe a ele a responsabilidade de introduzir políticas que induzem o processo de inovação nas empresas, como incentivos fiscais e criação de habitats ou ambientes especializados, aproximando e facilitando a cooperação entre UniversidadesEmpresas.

A Estratégia Nacional de Ciência, Tecnologia e Inovação 2016-2019 (ENCTI), diz explicitamente isso, o Estado deverá promover essa interação, especialmente através da criação de um milieu capaz de induzir e criar inovação tecnológica:

“3. o estreitamento da interação da ciência com os setores empresarial e governamental, por meio da criação de novos institutos/laboratórios, com a função de produzir e transferir tecnologias para o setor empresarial, visando a geração de conhecimento aplicado voltado para a inovação tecnológica de nível internacional. Tais institutos deverão ser capazes de realizar grandes projetos mobilizadores, para induzir o surgimento de setores econômicos novos e de ponta ou expandir e modernizar os existentes;" (ENCTI, 2016). 
Mais recentemente, em janeiro de 2016, foi publicado o novo marco legal da inovação no Brasil, a lei 13.243/16. Nela reitera-se os princípios para a promoção do desenvolvimento das atividades científicas e tecnológica além da possibilidade do ente público participar minoritariamente de ambientes de inovação:

\footnotetext{
Art. 5o São a União e os demais entes federativos e suas entidades autorizados, nos termos de regulamento, a participar minoritariamente do capital social de empresas, com o propósito de desenvolver produtos ou processos inovadores que estejam de acordo com as diretrizes e prioridades definidas nas políticas de ciência, tecnologia, inovação e de desenvolvimento industrial de cada esfera de governo.
}

Abre-se, então, uma nova e importante perspectiva para entes públicos como as Universidades públicas, a constituição de uma entidade privada para desenvolvimento da inovação tecnológica.

\subsection{RELATO DA EXPERIÊNCIA}

O autor do trabalho possui um perfil pautado pelo empreendedorismo e inovação. Sua primeira experiência empreendedora foi a venda de uniformes similares durante os estudos secundários.

Em 1996, fundou juntamente com seu sócio dos uniformes, seu primeiro negócio que prospera ainda hoje. Trata-se da empresa A Systems Ltda (www.asystems.com.br) que possui como foco a oferta de soluções de missão crítica para ambientes de tecnologia da informação. Esta também foi uma iniciativa empreendedora, uma vez que deixando um estágio num distribuidor IBM (Ivix), materializamos a idéia de adquirir componentes para equipamentos de alta performance nos Estados Unidos e fornecê-los no Brasil. O negócio mostrou-se viável, e muito rapidamente conseguimos montar uma carteira de clientes de prestígio. Em 1999, inovamos nosso modelo de negócio com a oferta de hardware como serviço e a inclusão de serviços de manutenção 24 horas por dia, com peças inclusas.

Em 2005, fundamos uma nova empresa (Comex Comérico e Importação e Distribuição Ltda) com foco na distribuição de produtos eletrônicos para grandes magazines. O projeto 
durou 5 anos, alcançando um mercado superior a 10.000 pontos de vendas. Todavia, com margens muito apertadas e um modelo de negócio frágil, devido ao financiamento da venda (compra à vista e recebimento a prazo) limitou o crescimento do negócio e os riscos dos mesmos. Assim, em 2013 os sócios decidiram abandonar o projeto.

Em 2009, iniciamos um novo empreendimento com a finalidade de prestar serviços de consultoria para empresas inovadoras utilizando os incentivos fiscais da Lei do Bem. Em 2010, fomos adquiridos pela francesa Global Approach Consulting (GAC), consultoria global especializada na obtenção de crédito fiscal oriundo dos investimentos em inovação tecnológica. Por 5 anos, o autor desempenhou o papel de principal executivo, conseguindo levar a empresa à liderança do mercado nacional com seus mais de 200 clientes locais, que somam investimentos acima de R \$ 1bi em inovação tecnológica. Em 2015, deixou a gestão para dedicar-se em outros empreendimentos inovadores.

Em 2015, ingressou no Mestrado Profissional em Empreendedorismo e Inovação da Faculdade de Administração da USP (FEA). Em contato com a Agência USP de Inovação vem desenvolvendo projetos para interação Universidade-Empresa.

Em 2016, inicia o processo de aquisição de um startup inovadora na área de Óleo e Gás, contando com uma patente internacional para detecção de vazamentos em dutos. Atualmente, possui projetos tanto no Brasil como em diversos países como Estados Unidos, México, Peru, Europa e Oriente Médio.

Possui como formação acadêmica um bacharelado em Direito pela Faculdade de Direito de São Bernardo do Campo, pós-graduação na Fundação Instituto de Administração (FIA/USP) em Ciência, Tecnologia e Inovação. Master Degree pela Université GrenobleAlpes (França) em Gestão de Empresas com foco em comércio internacional, além de especialização em gestão da inovação pela Bentley University, MA e North Caroline State University, NC, ambas nos Estados Unidos. 


\subsection{SITUAÇÃO PROBLEMA}

Segundo o estrategista Andy Bruce (2009) empresas de todos os países e de todos os setores de atividade precisam inovar para sobreviver e prosperar.

No contexto brasileiro, a competitividade das empresas brasileiras vem sofrendo muito com competidores internacionais num ambiente largamente globalizado. O reflexo desta situação materializa-se nos níveis de produtividade da economia brasileira, que quando comparadas com outros países tem mantido praticamente os mesmos níveis desde a década de 1980, conforme ilustra o gráfico 1 a seguir:

\section{Gráfico 1 - Crescimento da Produtividade}

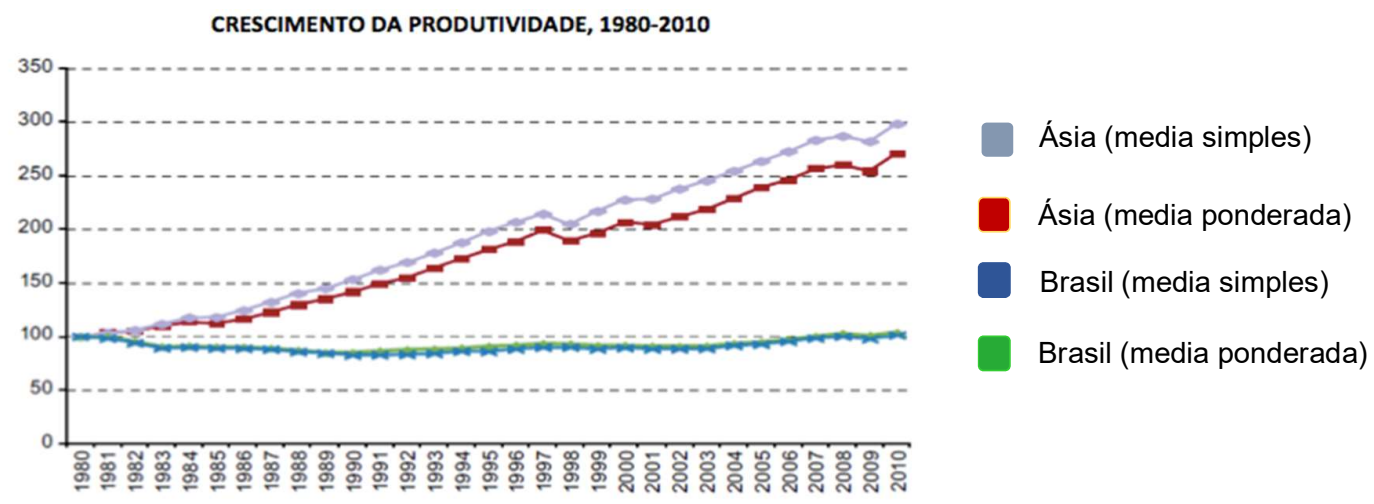

Fonte: BID - ECLAC, Índice 1980=100) apud Glauco Arbix apresentação IEA-USP, 2014

Através deste gráfico pode ser observado que o Brasil encontra-se com baixo índice de produtividade se comparado à outros países.

Mas o que fazer para ampliar o desenvolvimento de uma economia? A ciência e a tecnologia são poderosas ferramentas para o desenvolvimento de uma economia, seja pela geração de emprego e renda, seja pelo aumento do valor agregado em bens e serviços. Entretanto, de acordo com o ENCTI 2016, 
“A despeito dos recentes avanços, persiste o hiato existente entre o Brasil e países mais desenvolvidos no tocante a produção científica e tecnológica. Para a alteração deste quadro é necessária a construção de uma Política de CT\&I que leve em conta quais são os desafios a serem superados e quais são as oportunidades existentes a serem exploradas, sempre levando-se em conta as vantagens competitivas nacionais. (pg. 22)"

Dentre os vários mecanismos para incentivar a inovação podemos citar principalmente os seguintes (ENCTI, 2016):
a. Desenvolvimento de Talentos
b. Cooperação entre Universidade-Empresa
c. Criação de Redes de Institutos de Inovação
d. Mecanismos de financiamento diretos e indiretos
e. Redução da burocracia

Verifica-se que os ambientes especializados em inovação são uma das estratégias chaves na visão dos 'policemakers' (WESSNER, 2009), pois ele propicia num mesmo espaço físico o estímulo e o fluxo de conhecimento entre a universidade, institutos de pesquisa, empresas e mercado, facilitando a criação de novas tecnologias, além do fornecimento de serviços de valor agregado, comprometimento de financiamento público, criando uma “comunidade de inovação" com perfil tecnológico e de alto prestígio no ecossistema.

O Brasil tem adotado esse conceito e os efeitos dessa política podem ser observados pelo grande número de ambientes especializados, os conhecidos Parques Tecnológicos, inaugurados durante a última década. De acordo com o estudo do MCTI e a UnB (2014), a evolução dos parques científicos no Brasil tem a seguinte trajetória ilustrada através do gráfico 2 a seguir. 
Gráfico 2 - Evolução dos Parques Tecnológicos no Brasil

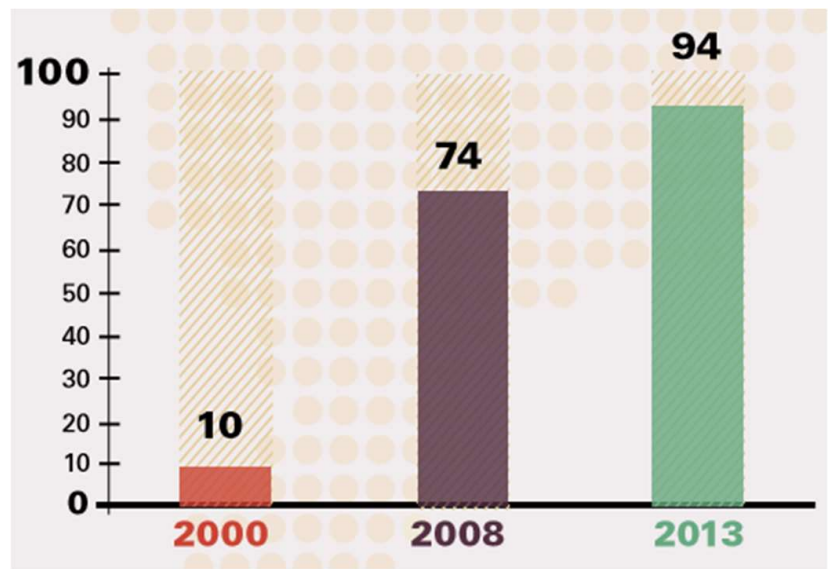

Fonte: CDT/UnB 2014 pág. 21.

Entretanto, a cidade de São Paulo, muito embora seja reconhecida como principal pólo econômico, financeiro e cultural da América Latina, não possui ainda um Parque Tecnológico implantado, muito embora exista um projeto bastante audacioso, em execução (BAGNATO, 2017; MELO, 2014; ZOUIN, 2003). Porém, diversas dificuldades, conforme relata o então Subsecretário de Ciência Tecnologia e Inovação do Estado de São Paulo, Prof. Dr. Marcos Cintra (in BAGNATO et al., 2017) tem retardado sua implantação como marcos regulatórios, responsabilidades de gestão e financiamento público e desapropriações.

\subsection{QUESTÃO DE PESQUISA}

Neste contexto a questão que propomos para este trabalho é responder:

Como um ambiente especializado em inovação pode estimular a interação entre o setor público, privado e acadêmico.

\subsection{OBJETO DE PESQUISA}

A parir do contexto exposto, o objetivo deste estudo é: 
Propor um modelo de Entidade de Ciência e Tecnologia privada que promova a interação entre a Universidade de São Paulo e empresas privadas, tendo como resultante um ambiente competitivo de inovação para a transformação do conhecimento em resultado econômico.

Para o completo atingimento deste objetivo foram estabelecidos os seguintes objetivos específicos:

(1) Descrever o Sistema de Inovação Brasileiro.

(2) Identificar os Incentivos Fiscais para Ambientes de Inovação.

(3) Definir as diretrizes para o planejamento estratégico de um núcleo do

Parque Tecnológico.

\section{$1.5 \quad$ JUSTIFICATIVA}

O professor da London Business School, Gary Hamel, afirma que vive-se uma nova ordem industrial.

"Estamos deixando para trás um mundo no qual escala, eficiência e replicação era tudo. Estamos agora dando passos para um mundo onde a imaginação, experimentação e a agilidade, se não for tudo, é ao menos, o catalisador para geração de riqueza” (HAMEL, G. 1999, pág. 30).

Esta transição para uma sociedade do conhecimento, também trouxe modificações nas relações e cooperação entre os atores e mecanismos de inovação, inclusive aumentando o processo de aproximação de empresas e universidades, como a criação de ambientes especializados em inovação, os chamados Parques Tecnológicos.

\footnotetext{
"A abordagem do meio inovador insere-se, portanto, nesta visão interativa e sistêmica da inovação, destacando a importância do espaço no fomento do processo inovador". (MELO, R., 2015, pág. 36).
}

Entretanto, o que se observa é que a interação empresa-universidade, no Brasil, ainda é relativamente baixa quando comparada com países com sistemas de inovação maduros. Este distanciamento possui várias razões como a formação tardia de nosso Sistema Nacional de Inovação, que se reflete numa certa persistência no modelo linear da 
inovação, onde o foco de fomento estava centrado na oferta das pesquisas e não tanto na interação entre os diferentes agentes, corroborando assim pelo distanciamento entre as universidades e o setor produtivo (IPEA, 2013).

"No Brasil, até o final dos anos 1960 o pensamento oficial era de que o país deveria se capacitar para absorver a tecnologia estrangeira, como forma de queimar etapas no processo de industrialização (...). A absorção da tecnologia seria feita utilizando os recursos humanos qualificados, disponíveis no país, e a infraestrutura dos institutos de pesquisa governamentais, o que demandaria baixos investimentos” (SBRAGIA, et al. 2006, pág. 91).

Os mecanismos de incentivo à inovação tecnológica são poderosas ferramentas para impulsionar o processo de inovação (OCDE, 2005). Todavia, o bom desempenho do sistema de inovação além de um parque de pesquisa amplo e moderno, requer também um elevado grau de interação com o setor produtivo (IPEA, 2013).

Portanto, a oferta de um ambiente especializado em inovação onde empresas pudessem estabelecer seus centros de inovação em São Paulo, seria então um mecanismo para auxiliar na mudança deste cenário negativo.

Neste contexto, a Universidade de São Paulo desempenha um papel de liderança na produção científica não só do Brasil, mas da América Latina, e tem um papel importante na transferência de conhecimento para o mundo corporativo. Por sua relevância, tal universidade é a fonte de estudo do presente trabalho.

Em 2005, a Universidade de São Paulo, através da Resolução USP $n^{0} 5175$ de 18/02/2005, criou a Agência USP de Inovação como Núcleo de Inovação Tecnológica (NIT) da USP, que possui como objetivo:

Identificar, apoiar, promover, estimular e implementar parcerias com os setores empresariais, governamentais e não governamentais na busca de resultados para a sociedade.

Neste contexto, o estudo de um modelo que pudesse, mesmo em escala reduzida, proporcionar esta relação universidade-empresa seria de grande interesse. Também a Universidade de São Paulo está atenta a esta realidade. 
"A Universidade de São Paulo é referência nacional e, portanto, deve sim se preocupar em realizar os primeiros passos na direção de criarmos um Parque Tecnológico na cidade de São Paulo. Através da Agência USP de Inovação diversas atividades em prol da formação de um Núcleo do Parque Tecnológico estão em curso”. (BAGNATO et al., 2017, pág. 9) 


\section{2- ESTRUTURA DO TRABALHO}

A estrutura do trabalho apresenta uma característica multidisciplinar não podendo ser enquadrado em uma única área do conhecimento.

"O tema inovação e, consequentemente, as suas vertentes de sistema de inovação e ambientes de inovação são abrangentes, podendo ser citados em diferentes áreas do conhecimento, como as ciências sociais aplicadas, em disciplinas de Economia e Administração; também no corpo das Engenharias com enfoque da engenharia de produção, ou em áreas relacionadas ao Urbanismo, a Geografia Espacial e mesmo Políticas Públicas” (SILVA, 2009).

O trabalho está dividido basicamente em uma parte introdutória composta pela introdução, experiência do autor - estamos diante de um programa de Mestrado Profissional, que passa da prática para a teoria - objeto de pesquisa e justificativa.

Uma segunda parte trata do Referencial Teórico, que busca na releitura da literatura em três grandes pontos: o Sistema de Inovação, Ambientes de Inovação com um enfoque nos ambientes especializados e, por fim, o Financiamento da Inovação.

A parte metodológica que vai tratar das coletas de dados através de pesquisas qualitativas através de entrevistas e dados secundários referentes ao objeto de estudo.

Por fim, o modelo proposto é então aplicado ao caso da Universidade de São Paulo através do Núcleo do Parque Tecnológico da USP.

A figura 2 exemplifica a estrutura do presente trabalho. 


\section{Figura 2 - Estrutura do Trabalho}

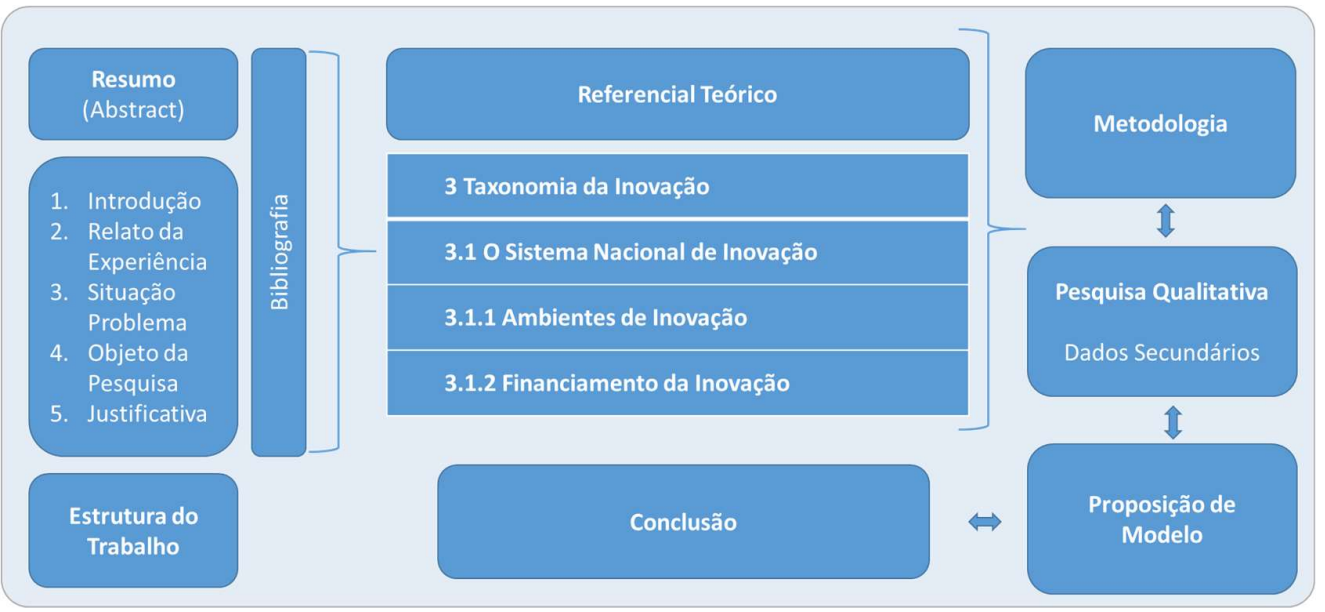

Fonte: Elaborado pelo autor. 


\section{3- FUNDAMENTAÇÃO TEÓRICA}

\subsection{Taxonomia da Inovação}

A inovação pode simplesmente ser definida como algo novo que agregue valor social ou riqueza (TIDD, 2008). Neste sentido, a inovação propriamente dita é aquela que venceu os vários riscos associados, tanto tecnológicos como mercadológicos, e chegou ao mercado, gerando valor para os stakeholders envolvidos (CARVALHO, 2009).

De acordo com o manual internacional de OSLO, a inovação é definida como:

"a implementação de um produto (bem ou serviço) novo ou significativamente melhorado, ou um processo, ou novo método de marketing, ou um novo método organizacional nas práticas de negócios, na organização do local de trabalho ou nas relações externas" (OSLO, 1997, pág. 55).

Ou seja, as inovações são criações de significância econômica normalmente realizadas por empresas. Podem ser uma novidade, porém normalmente são novas combinações de elementos já existentes”. (EDQUIST, 2001).

\footnotetext{
"A inovação visa melhorar o desempenho de uma empresa com o ganho de uma vantagem competitiva (ou simplesmente a manutenção da competitividade) por meio da mudança da curva de demanda de seus produtos (por exemplo, aumentando a qualidade dos produtos, oferecendo novos produtos ou conquistando novos mercados ou grupos de consumidores), ou de sua curva de custos (por exemplo, reduzindo custos unitários de produção, compras, distribuição ou transação), ou pelo aprimoramento da capacidade de inovação da empresa (por exemplo, aumentando sua capacidade para desenvolver novos produtos ou processos ou para ganhar e criar novos conhecimentos"(OSLO, 1997 pág. 43).
}

As categorias de inovação são complexas e heterogêneas e podem incluir "processos", bem como "produtos", como indicado abaixo: 


\section{Figura 3 - Taxonomia da Inovação}

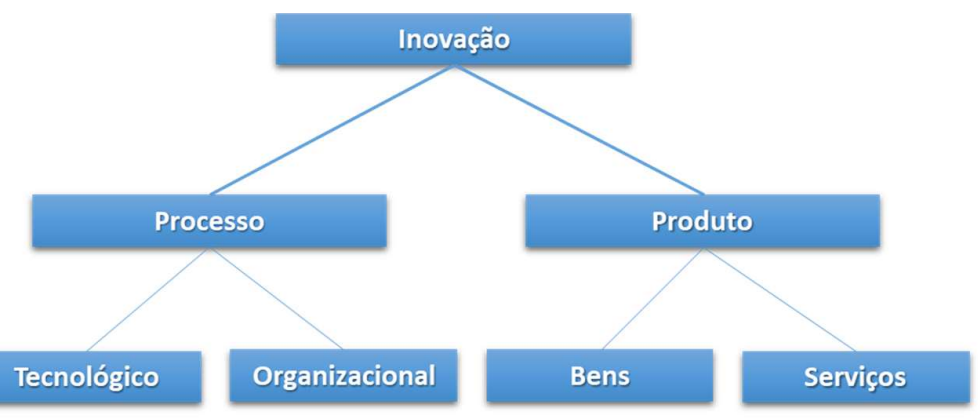

Fonte: Adaptado a partir de EDQUIST (2001, pág. 07)

Seguindo ainda o Manual de Oslo, a inovação pode ser dividida em quatro áreas:

\section{- Inovação de Produto}

É a concepção de um bem/serviço novo ou significativamente melhorado com relação aos produtos existentes. Responde à pergunta "o que está sendo Produzido".

- Inovação de Processo

É a implementação de um método de produção ou distribuição novo ou significativamente melhorado. Responde à pergunta "como está sendo produzido".

\section{- Inovação Organizacional}

Implantação de um novo método organizacional, que pode ser uma nova prática de negócio da empresa, um novo modelo de negócio. Edquist faz uma observação interessante, dizendo que as inovações organizacionais são "intangíveis", cuja importância vem aumentado para o crescimento econômico.

\section{- Inovação Marketing}

Novos métodos de marketing, como mudanças no design do produto e na embalagem. 
O pré-requisito que marca a inovação é a questão da novidade, o produto ou processo precisa ser novo para a empresa.

“O requisito mínimo para se definir uma inovação é que o produto, o processo, o método de marketing ou organizacional sejam novos (ou significativamente melhorados) para a empresa. Isso inclui produtos, processos e métodos que as empresas são as pioneiras a desenvolver e aqueles que foram adotados de outras empresas ou organizações.” (OSLO, 1997 p.56).

A inovação é afetada por vários fatores e segundo Tidd et al. (2008); Prahalad e Krishnan (2008); Christensen (2001) os principais são: liderança, comunicação, cultura, competências; estrutura, recursos humanos e financeiros e de acordo com Gibbons et al.(1974) as fontes de inovação podem derivar basicamente de 3 origens:

Tabela 1 - Fontes de Inovação

\begin{tabular}{|l|l|l|}
\hline Externas & Internas & Pessoais \\
\hline $\begin{array}{l}\text { Literatura técnica e do } \\
\text { Ramo }\end{array}$ & Análise e experimentação & Experiência na empresa \\
\hline $\begin{array}{l}\text { Manuais e literatura } \\
\text { científica }\end{array}$ & $\begin{array}{l}\text { Superiores hierárquicos ou } \\
\text { colegas }\end{array}$ & $\begin{array}{l}\text { Experiência em outras } \\
\text { empresas }\end{array}$ \\
\hline Universidades e Cientistas & $\begin{array}{l}\text { Outro departamento ou } \\
\text { divisão da empresa }\end{array}$ & $\begin{array}{l}\text { Formação acadêmica } \\
\text { prévia }\end{array}$ \\
\hline $\begin{array}{l}\text { Departamentos } \\
\text { governamentais }\end{array}$ & $\begin{array}{l}\text { Manuais ou relatórios da } \\
\text { empresa }\end{array}$ & $\begin{array}{l}\text { Literatura Técnica e do } \\
\text { ramo }\end{array}$ \\
\hline $\begin{array}{l}\text { Fornecedores, agentes, } \\
\text { testes de mercado }\end{array}$ & & Outros fatores \\
\hline Feiras & & \\
\hline Consultores comerciais & & \\
\hline Assistentes de investigação & & \\
\hline
\end{tabular}

Fonte: A partir Gibbons (1974), apud PARANHOS 2012, pág. 20. 


\subsection{Modelo de Inovação Fechada e o Modelo de Inovação Aberta}

"A maioria das inovações fracassa. E as empresas que não inovam morrem" (CHESBROUGH, 2012). É com essa chocante, porém verdadeira afirmação que o Professor Henry Chesbrough inicia seu mundialmente famoso livro "Inovação Aberta, como criar e lucrar com a tecnologia”.

O modelo de inovação fechada é aquela concepção onde a inovação de sucesso exige controle, onde "as companhias precisam gerar suas próprias ideias e, em sequência, desenvolvê-las, construí-las, comercializá-las, distribuí-las, assessorá-las e dar-lhe todo o suporte possível para a concretização do sucesso" (CHESBROUGH, 2012 pág. 4).

Segundo o Chesbrough (2012, pág. 4), as principais regras implícitas da inovação fechadas são as seguintes:

- Precisamos contratar os melhores e mais brilhantes profissionais a fim de que tenhamos sempre, trabalhando conosco, os mais capazes da indústria;

- Para colocar novos produtos e serviços no mercado, precisamos descobrí-los e desenvolvê-los por nossa conta;

- Sempre que fizermos a descoberta adequada, chegaremos ao mercado antes de qualquer eventual concorrente;

- A companhia que levar inovação ao mercado em primeiro lugar normalmente será a vencedora;

- Se liderarmos a indústria em termos de investimentos de $P \& D$, certamente descobriremos as ideias melhores e mais úteis, e com isso seremos igualmente líderes do mercado; e

- Precisamos controlar nossa propriedade intelectual a fim de impedir que os concorrentes venham a lucrar com a nossas ídeia.

Durante boa parte do século XX esse paradigma foi seguindo pelas principais empresas que investiam seriamente em inovação. 
A representação desse modelo fechado de inovação pode ser visto na figura abaixo:

\section{Figura 4- O paradigma fechado da gestão de P\&D fechado}

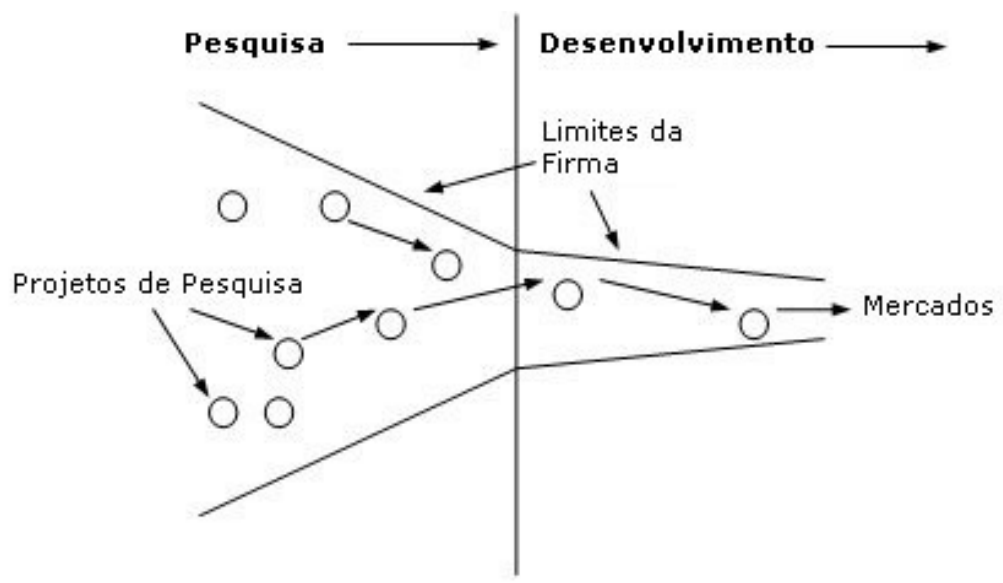

Fonte: Adaptado de CHESBROUGH, H. 2012 pág. 47

Esse modelo foi aplicado durante muito tempo, especialmente por conta da comunidade científica da época (início e grande parte do século XX) "entenderem que os cientistas não deveriam, de forma alguma, aplicar seus talentos e treinamentos a problemas comercias" (CHESBROUGH, 2012 pág. 38), a busca do conhecimento prático era considerada como uma ciência "prostituída".

O governo também não desempenhava um papel muito significante no sistema de pesquisa.

Portanto, "se as universidades e o governo não estavam liderando a aplicação comercial da ciência, o que então conseguia fazer avançar esses progressos técnicos? A indústria era a fonte principal do financiamento de pesquisas para o uso comercial da ciência, e os laboratórios de P\&D das indústrias eram o centro principal dessa pesquisa industrial" (CHESBROUGH, 2012, pág. 39.)

Ao final da II Grande Guerra, verificou-se um princípio de mudança da concepção do papel do Estado nos esforços de aquisição do conhecimento. O Presidente Roosevelt encomenda um estudo para o Prof. Vannevar Bush do Massachusetts Institute of 
Technology (MIT) para organizar os estudos e conhecimento científico para problemas técnicos:

“O Escritório de Pesquisa e Desenvolvimento Científico [...] representa uma experiência única de trabalho [...] na aplicação do conhecimento científico existente para a solução de problemas técnicos fundamentais na guerra [...]. É possível propor um programa eficaz para a descoberta e o desenvolvimento de talentos científicos na juventude americana, para que o futuro da pesquisa científica neste país fique assegurado num nível comparável ao dos tempos de guerra? Novas fronteiras para a mente estão diante de nós. Se forem exploradas com a mesma visão, arrojo e ímpeto com os quais empreendemos esta guerra, poderemos criar melhores empregos, mais frutíferos; e uma vida melhor e mais frutífera". (Roosevelt, F. Letter to Dr. Vannevar Bush, 17-nov-1944).

Vários fatores passaram a surgir a partir da metade do século XX, que transformaram esse cenário de inovação fechada culminando com o fimm dos monopólios do conhecimento.

Segundo Chesbrough, a alta disponibilidade de especialistas e a expansão da pesquisa científica nas universidades na medida que o financiamento dos governos para pesquisa básica apresenta um real declínio, propiciou os professores a buscar apoio da indústria para suas pesquisas.

"Essa busca ajudou-os inclusive a se tornarem mais astutos com relação às necessidades e problemas da indústria. Suas agendas futuras de pesquisa passaram a refletir importantes problemas com os quais a indústria passa a se defrontar" (CHESBROUGH, pág. 61).

“A inovação aberta significa que ideias valiosas podem surgir a partir do interior e/ou exterior da companhia, bem como podem ir para o mercado." (CHESBOURGH, 2012, pág. 59). 


\section{Figura 5 - Paradigma da Inovação Aberta}

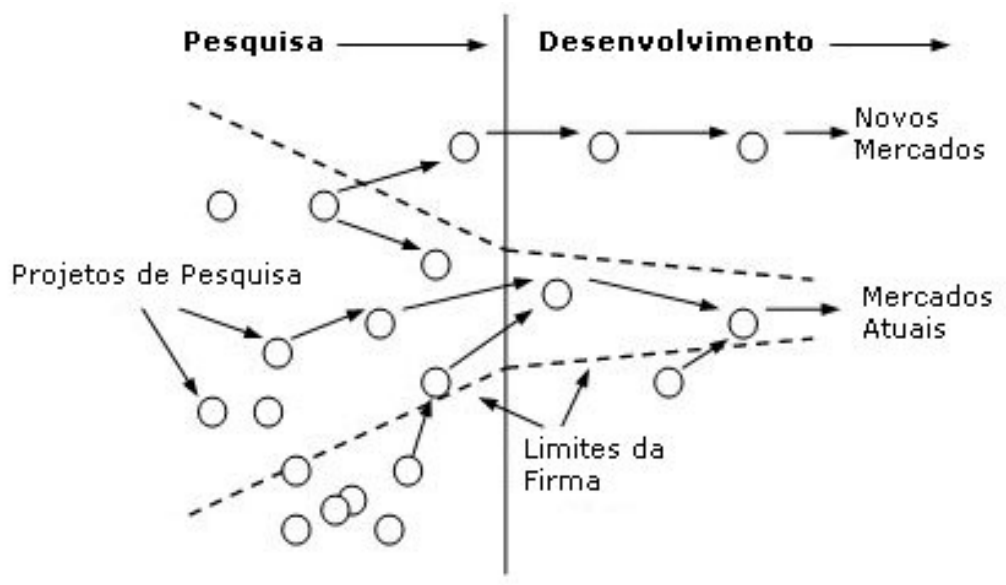

Fonte: Adaptado de CHESBROUGH, H. 2012, pág. 60.

O novo paradigma da inovação aberta não é uma condenação da inovação fechada, onde as empresas devam desativar suas atividades de P\&D internas, mas "qualquer que seja a pesquisa feita internamente, deverá levar em consideração a riqueza de atividades no entorno da empresa" (CHESBROUGH, 2012 pág. 68).

\subsection{SISTEMAS DE INOVAÇÃO}

Muito embora Schumpeter (1988) já indicava a inovação como elemento fundamental para o desenvolvimento econômico, a mesma era ainda vista no final da década de 60 como um processo interno, sucessivo e linear, passando pela pesquisa básica, pesquisa aplicada, desenvolvimento, produção e difusão (CASSIOLATO e LASTRES, 2005).

Dois principais estudos acadêmicos sobre inovação lapidaram seus conceitos sistêmicos como um processo não-linear, cumulativo e local. O primeiro deles foi o projeto SAPPHO sob a coordenação do professor Chris Freeman da Universidade Sussex. O segundo tratase do Yale Innovation Survey com o professor Alvin Klevorick e finalmente o Sundquist Report (OECD, 1988) que incorporou as novas ideias sobre "sistemas de inovação" aos documentos de políticas da OCDE quais sejam: 
- $\quad$ Formação de redes de cooperação;

- $\quad$ Parcerias estratégicas;

- Spillovers;

- Importância do Conhecimento Tácito.

"A empresa deve ser parte de um Sistema Nacional de Inovação (SNI), que pode ser definido como uma rede de instituições públicas e privadas que interagem para promover o desenvolvimento científico e tecnológico de um país. Inclui empresas, dos mais variados tipos, associações empresariais, universidades, escolas técnicas, institutos de pesquisa, governo, agências de fomento e agências reguladoras, num esforço de geração, importação, modificação, adaptação e difusão de inovações tecnológicas.” (SBRAGIA, et al. 2006, pág. 19).

A inovação passa a ser tratada não mais como uma estratégia de política industrial, mas como estratégia de desenvolvimento. A inovação enquanto sistema passa a ser conceituada como "um conjunto de instituições distintas que contribuem para o desenvolvimento da capacidade de inovação e aprendizado de um país, região, setor ou localidade - e também o afetam. Constituem-se de elementos e relações que interagem na produção, difusão e uso do conhecimento.” (CASSIOLATO; LASTRES, 2005).

Na América Latina as discussões sobre um sistema de inovação também ocorriam desde 1968, quando Jorge Sábato e Natálio Botana apresentavam seu trabalho na Itália no World Order Model Conference (OLIVEIRA, 2010).

"Quatro foram os argumento expostos: a maior eficiência na absorção de tecnologias (cuja importação, aliás, os autores reputavam como necessária a qualquer país), pela existência no país receptor "de uma sólida infra-estrutura científico-tecnológica"; a especificidade das condições de cada país para conseguir uma utilização inteligente dos fatores de produção; a necessidade de passar a exportar bens com maior valor agregado; e o fato de que ciência e tecnologia são catalisadores da mudança social”. (PLONSKI, 1995).

Seu modelo ficou conhecido como "Triângulo de Sábato” em cujos vértices localizam-se o governo, as instituições de ensino e pesquisa e, por fim, as empresas. 
Figura 6 - O Triângulo de Sábato

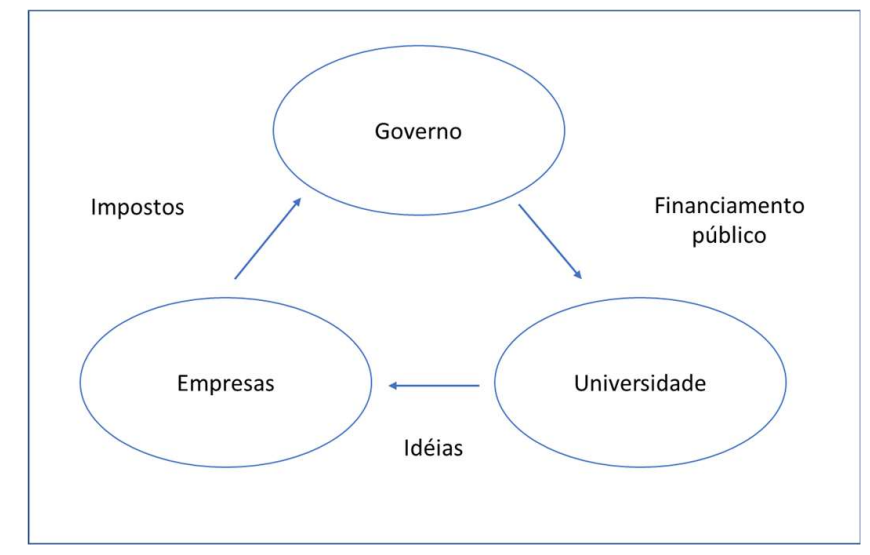

Fonte: SBRAGIA et al. 2006, pág. 20.

O papel do Estado passa a ter uma função toda especial concretizando pela formação de novas instituições (agências de fomento, centros de pesquisas, etc) e implementação de ações que permitam e estimulem as empresas e demais atores locais a interagirem corrigindo ou compensando imperfeições do mercado.

"Mais recentemente, surgiu a metáfora da Hélice Tríplice, que foi criada para descrever o aparecimento de novos empreendimentos dentro e fora da universidade, que envolvem cooperação entre os diversos atores do processo de inovação - universidade, indústria e governo." (SBRAGIA et al. 2006, pág. 20).

Etzkowitz e Leydesdorff (1995;2000) criaram um modelo para representar o sistema de inovação e seu funcionamento a partir da interação entre três esferas institucionais: universidade, indústria e governo. "Cada uma dessas esferas representa uma hélice que interage em três dimensões com as demais. A primeira dimensão ocorre no interior de cada hélice com a transformação de cada um dos atores, como nas alianças estratégicas entre as empresas e na inclusão de uma nova missão da universidade. A segunda dimensão é a influência de uma hélice sobre a outra na interação entre os atores de diferentes dimensões institucionais para a geração de inovação, como ocorre na aprovação governamental da legislação que estimula a transferência de tecnologia das universidades para as empresas. A terceira dimensão é a criação de instituições trilaterais híbridas oriundas da interação entre as três hélices com o objetivo de apresentar propostas de desenvolvimento de alta tecnologia, como centros tecnológicos, incubadoras de 
empresas, universidades corporativas e instituições governamentais de capital de risco" (PARANHOS, 2012).

\section{Figura 7 - Modelo da hélice tríplice}

\section{HÉLICE TRIPLA III}

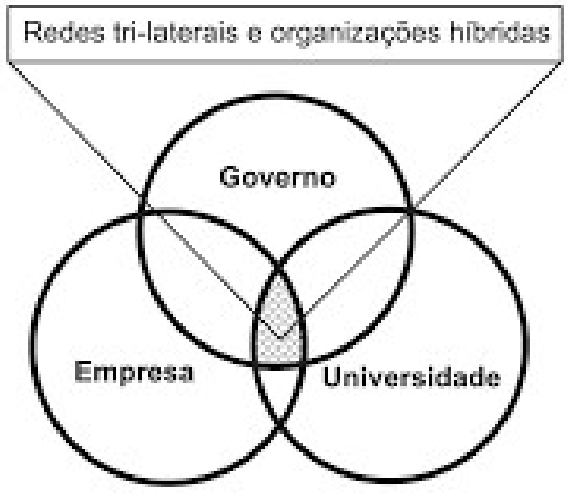

Fonte: PARANHOS, 2012, pág. 13.

No Brasil, a inovação começou a fazer parte de políticas públicas a partir da década de 90, principalmente com a Lei de Informática (8.241/91) e posteriormente já no novo milênio com as Lei de Inovação (10.973/04) e Lei do Bem (11.196/05) e o novo marco legal (13.243/2016) que serão tratadas adiante de forma mais detalhada.

Associação Nacional de Pesquisa e Desenvolvimento das Empresas Inovadoras (ANPEI) fez um trabalho de mapear os diversos fluxos entre os atores que participam do ecossistema do Sistema Brasileiro de Inovação através do Comitê Interação ICTEmpresa. $\mathrm{O}$ resultado deste trabalho de pesquisa resultou no mapa da figura 8 abaixo: 


\section{Figura 8 - Mapa Teórico do Sistema Brasileiro de Inovação}

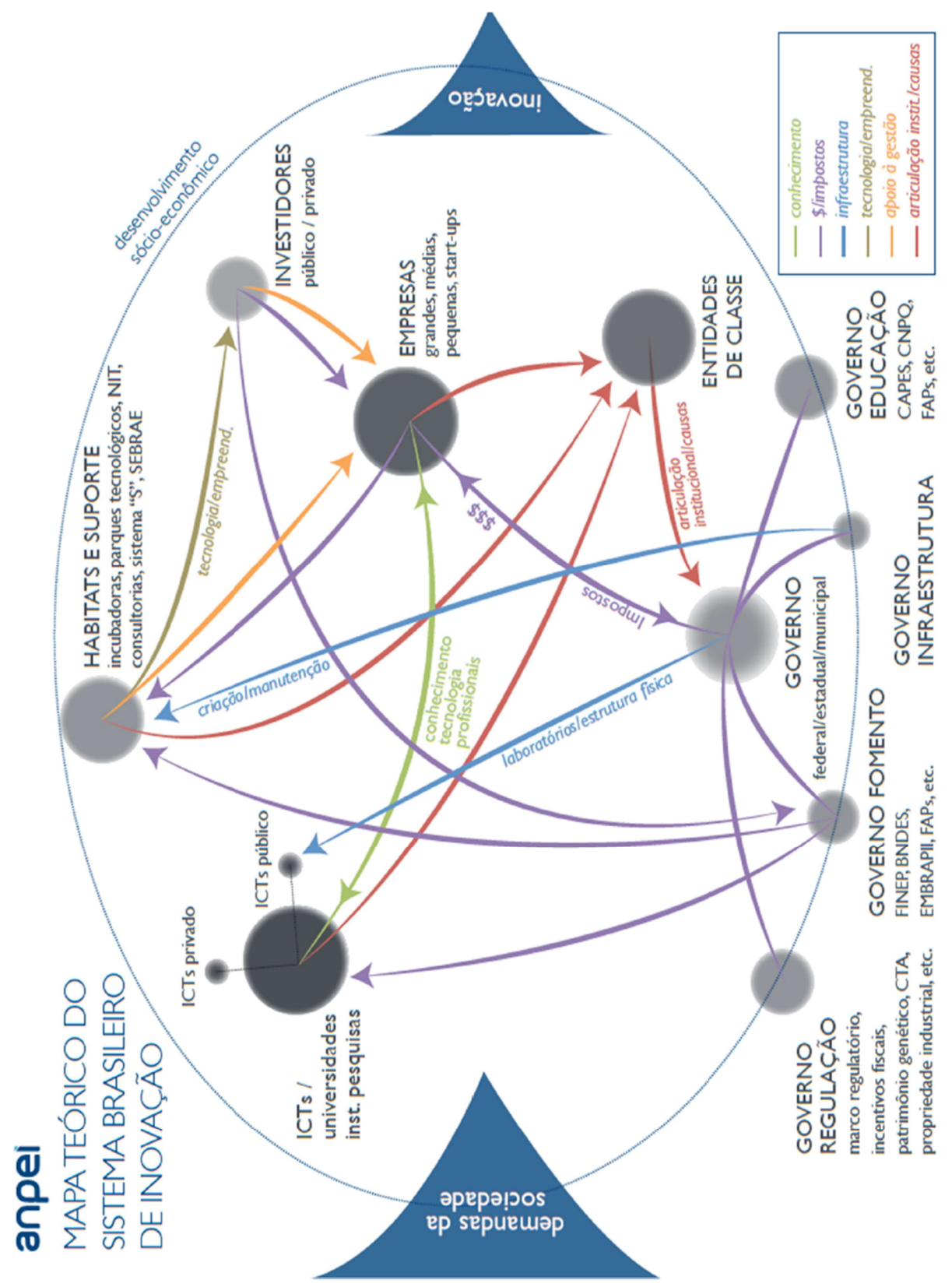

Fonte: ANPEI, disponível em: http://www.educanpei.org.br/web/anpei/mapa

\subsection{AMBIENTES DE INOVAÇÃO}

A alteração do modelo de gestão da inovação, fechada para aberta, ocorrida nos meados do século XX, gerou uma reflexão maior para a questão dos espaços especializados ou ambientes de inovação, também conhecido por habitats de inovação. 
O governo americano já havia identificado a importância do desenvolvimento tecnológico e investia de forma intensiva nas universidades e indústria. "Uma nação que depende dos outros para seus novos conhecimentos científicos básicos é vagarosa em seu progresso industrial e fraca em sua posição competitiva no comércio mundial, qualquer que seja seu nível de capacidade mecânica” (VANNEVAR, B, 1945).

Neste novo paradigma, “as empresas não inovam isoladamente, geralmente o fazem no contexto de um sistema de redes de relações diretas ou indiretas com outras empresas, a infraestrutura de pesquisa pública ou privada." (SBRAGIA, 2006).

Os ambientes especializados, que unificam em um mesmo complexo físico empresas e universidades começam a ganhar relevância, em vista do desenvolvimento tecnológico.

“O mais reverenciado ecossistema de inovação é a Região do Vale do Silício, cuja riqueza atualmente gerada compara-se a economia de alguns países. (...) O Vale concentra mais de $40 \%$ de todo o capital de risco voltado à inovação nos EUA.(...) Sua gênese e crescimento é endêmica, consequência de uma conjuntura e cultura locais extremamente propícias ao empreendedorismo de classe mundial. Seu surgimento, fortemente influenciado pela universidade de Stanford, ocorreu naturalmente na década de 50 devido a necessidade de conformar uma indústria de alta tecnologia nos Estados Unidos." (SPINOSA,L in BAGNATO 2017).

De acordo com CHESBROUGH, a grande virtude deste modelo não foi tanto a questão do aumento do investimento em inovação, mas sim "como" se investiu esse dinheiro.

“O governo financiaria pesquisa básica, mas a maior parte dessa pesquisa não seria realizada em laboratórios governamentais, em vez disso, ocorreria nas principais universidades acadêmicas, governadas por normas de inquérito e divulgação científicas" (CHESBROUGH, 2012).

A partir dos anos 80, segundo SILVA (2009 pág. 46), “o movimento de parques ganhou impulso, quando se evidenciaram as limitações em relação à eficácia das políticas econômicas tradicionais, assim como ao momento a inovação se consolidou como forma dominante de competição entre os países desenvolvidos. 
A Europa passa a adotar um sistema influenciado pelo modelo americano. Assim, no Reino Unido com a fundação do Cambridge Science Park em 1970 e na França, no mesmo ano, o projeto Sophia Antipolis é inaugurado.

As principais definições adotadas para Parques Científicos e Tecnológicos estão descritas na Tabela 2, abaixo.

Tabela 2 - Definições de Parques Científicos e Tecnológicos

\begin{tabular}{|c|c|}
\hline Fonte & \multicolumn{1}{|c|}{ Definição } \\
\hline ANPROTEC & $\begin{array}{r}\text { (a) Complexo industrial de base científico-tecnológica planejado, } \\
\text { de caráter formal, concentrado e cooperativo, que agrega } \\
\text { empresas cuja produção se baseia em pesquisa tecnológica } \\
\text { desenvolvida em centros de P\&D vinculados ao Parque; } \\
\text { (b) Empreendimento promotor da cultura da inovação da } \\
\text { competitividade, do aumento da capacitação empresarial } \\
\text { fundamentado na transferência de conhecimento e tecnologia, } \\
\text { com o objetivo de incrementar a produção de riqueza. }\end{array}$ \\
\hline IASP & $\begin{array}{l}\text { Um Parque Científico é uma organização gerida por profissionais } \\
\text { especializados, cujo objetivo fundamental é incremental a riqueza } \\
\text { de sua comunidade promovendo a cultura da inovação e da } \\
\text { competitividade das empresas e instituições geradoras de } \\
\text { conhecimento instaladas no parque ou associadas a ele. } \\
\text { Com este objetivo, um Parque Científico estimula e gere o fluxo de } \\
\text { conhecimento e tecnologia entre universidades, instituições de } \\
\text { pesquisa, empresas e mercados; promove a criação e o crescimento } \\
\text { de empresas inovadoras mediante mecanismos de incubação e de } \\
\text { "spin-off”, e proporciona outros serviços de valor agregado assim } \\
\text { como espaço e instalações de alta qualidade. }\end{array}$ \\
\hline
\end{tabular}

Fonte: ZOUIN (2003, pág. 34)

No Brasil, as primeiras ações para implantar o desenvolvimento de habitats de inovação tiveram início na década de 1980, “com a criação Programa Brasileiro de Parques Tecnológicos pelo CNPq. (...) Dados os desafios impostos pela falta de uma cultura direcionada à inovação e pelo baixo número de iniciativas inovadoras no território nacional, os projetos de parques tecnológicos da época não tiveram o impacto dos grandes 
centros mundiais de inovação, implicando resultados mais modestos". (ANPROTEC, 2014, pág. 12).

De acordo com a ANPROTEC (2008), a partir do ano 2000 os Parques Tecnológicos voltaram a crescer, e aponta as seguintes razões:

- Fortalecimento da consciência dos atores de governo acerca da importância da inovação para o desenvolvimento sustentável e crescimento econômico do país;

- Aumento significativo do número de empesas interessadas em se instalar em Parques Tecnológicos - empresas geradas ou graduadas em incubadoras, empresas multinacionais de tecnologia e empresas nacionais determinadas a fortalecer suas unidades de P\&D;

- Experiência bem sucedida de outros países como Espanha, Finlândia, França e Estados Unidos, Coréia, Taiwan, entre outros, que estão investindo de forma consistente neste mecanismo;

- Necessidade de governos estaduais e municipais identificarem novas estratégias de estimular o crescimento e direcionar o desenvolvimento de suas regiões. (ANPROTEC 2008, pág. 06).

"Dentro do contexto da tríplice hélice, a proximidade dos parques com institutos de pesquisa e universidades e os incentivos governamentais na promoção desses habitats de inovação têm propiciado aos setores público e privado um ambiente favorável ao desenvolvimento de inovações e à melhoria da competitividade de seus produtos, processos e serviços.” (ANPROTEC 2014, pág. 32).

No gráfico 3 abaixo é possível verificar esse crescimento de Parques Tecnológicos no Brasil: 
Gráfico 3 - Evolução dos Parques Tecnológicos no Brasil

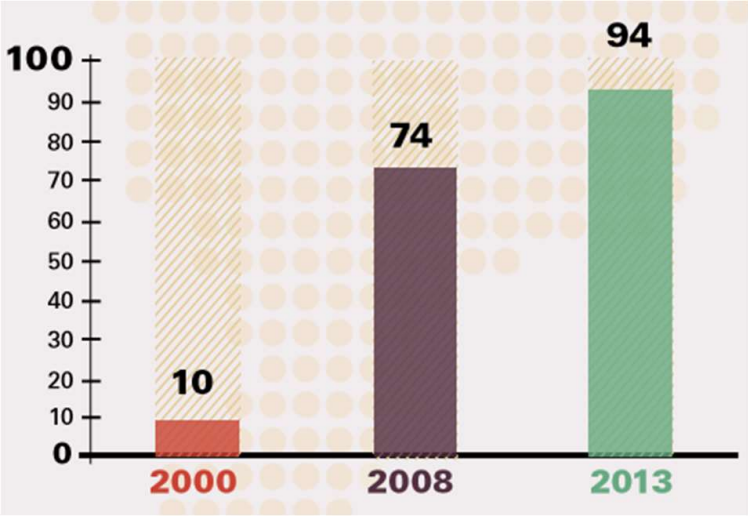

Fonte: CDT/UnB 2014, pág. 21.

De acordo ainda com o estudo da ANPROTEC (2014, pág ) a quantidade de empresas instaladas nestes Parques Tecnológicos é de 939 empresas, gerando 32.237 empregos, sendo 2.950 por profissionais com titulação de mestre, 2364 por diplomados em cursos de especialização e 17.630 por diplomados com formação máxima em nível superior.

O gráfico 4 destaca esses empregos nas empresas instaladas nos diversos Parques Tecnológicos do Brasil por nível de qualificação.

Gráfico 4 - Número de Empregados nos Parques Tecnológicos

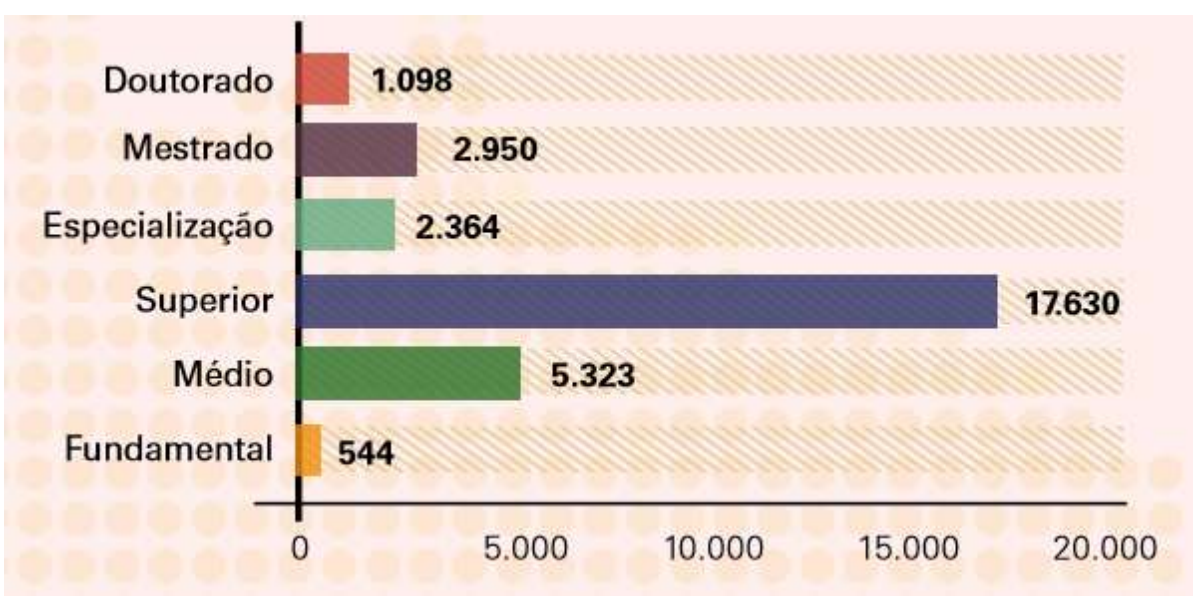

Fonte: CDT/UnB 2014, pág. 33.

De acordo com o Secretário Executivo do MCTI, Prof. Dr. Álvaro Toubes Prata, os parques tecnológicos "têm demonstrado eficiência na transferência de conhecimento de 
instituições de ciência e tecnologia para o setor empresarial. São as principais fontes qualificadoras e geradoras de base tecnológica, que se caracterizam pela forte agregação de tecnologia e inovação (...). Outro dado importante, (..) foi que, para cada $R \$ 1,00$ investido pelo governo federal na implantação e consolidação dos parques tecnológicos, foram capitalizados outros $\mathrm{R} \$ 4,00$ dos governos estaduais e municipais e da inciativa privada. Esse resultado é altamente significativo, com clara demonstração de que o governo federal está atuando corretamente no seu papel de indutor na implantação desses habitats de inovação.” (ANPROTEC 2014, pág. 4).

\subsubsection{Conjunto de Atividades em Parques Tecnológicos}

Segundo SILVA (2009, pág 42), embora os Parques Tecnológicos apresentem características bastante heterogêneas, esses habitats contam com alguns elementos constitutivos comuns, entre eles:

- Estímulo à geração de tecnologias: é o conjunto das ações voltadas ao desenvolvimento de conhecimento e da tecnologia. Nos parques tecnológicos, a estratégia mais comum para estimular o desenvolvimento tecnológico é a cooperação, representada pela interação entre universidade, instituições de pesquisa e empresas;

- Desenvolvimento de novas empresas de tecnologia: ações voltadas ao desenvolvimento do espírito e das ações empreendedoras. Em geral, nos parques tecnológicos, tais ações estão articuladas aos projetos de incubação de empresas de base tecnológica a partir dos quais o desenvolvimento de negócios inovadores é estimulado.

- Serviços de alto valor agregado: agrega o conjunto da infraestrutura disponibilizada pelo parque a fim de facilitar o processo de desenvolvimento de produtos e processos inovadores, como também, promover o crescimento desses negócios. Os serviços de alto valor agregados reúnem, além de espaços e instalações diferenciados em termos de qualidade, serviços de apoio, como assessorias, consultoria em marketing, comunicação, finanças e outros. 
- Interação entre os atores: é o conjunto de ações e de mecanismos facilitadores do processo de interação entre os agentes do parque. Além de dar suporte à estratégia para o desenvolvimento da tecnologia, a interação com outros atores como investidores, autoridades públicas, entre outros, caracterizam o ambiente diferenciado dos parques tecnológicos.

SILVA (2009, pág. 69) elenca os principais fatores para projetos de Parques Tecnológicos:

- Suporte das autoridades locais, regionais ou nacionais - a base de Ciência e Tecnologia é condição básica para o desenvolvimento de parques tecnológicos;

- Presença de instituições de pesquisa (creditícios e tributários) - definição de condições diferenciadas para o desenvolvimento dos parques tecnológicos, permitindo atrair empresas e investidores;

- Espaços para aglomeração de empresas de base tecnológica - oferta de espaços para as empresas desenvolverem as atividades;

- Infraestrutura básica (transporte, telecomunicações, energia e outros) - condições favoráveis e atrativas para receber os proprietários e funcionários das empresas do parque tecnológico;

- Qualidade ambiental e boa imagem urbanística - os projetos de parques tecnológicos devem estar em harmonia com os preceitos de desenvolvimento sustentável, sendo a construção condizente com empresas de base tecnológica;

- Capacidade de absorção de conhecimento aplicado e de inovação e de inovação presença de empresas com capacidade de prover parcerias e aplicar os conhecimentos gerados;

- Foco de mercado - definição da estratégia para atuação, podendo ser interno ou baseado em exportações.

De acordo com a ANPROTEC (2008, pág. 15) “as experiências acumuladas na área de incubadoras de empresas bem como os avanços nos instrumentos de fomento à inovação criam as condições favoráveis para promover a criação e atração de empreendimentos inovadores em Parques Tecnológicos. 
(...) Uma política bem-sucedida de apoio a Parques Tecnológicos exige a alocação de recursos significativos estáveis no longo prazo de forma a assegurar a implantação de projetos relevantes, diferenciados e duradouros".

\subsection{FINANCIAMENTO DA INOVAÇÃO}

De acordo com os dados da última Pesquisa de Inovação Tecnológica (PINTEC, 2014) divulgado pelo Instituto Brasileiro de Geografia e Estatística (IBGE), o setor industrial manteve os níveis de investimento em P\&D ao longo dos últimos anos, totalizando um volume de $\mathrm{R} \$ 22,7$ bilhões de Reais.

Porém, segundo LINHARES (2016), "na Pintec 2014, o elevado custo ocupou o primeiro posto como obstáculo à inovação na indústria $(86 \%)$, seguido pelos riscos $(82,1 \%)$ e pela escassez de fontes de financiamento $(68,8 \%)$ "'.

Portanto, a questão do financiamento é um tema relevante para todo o ecossistema de inovação brasileiro.

De acordo com o ENCTI 2016 (pág, 42) existem basicamente quatro tipos de fonte de financiamento:

1) Os Orçamentos da Administração Pública Federal

2) Os Recursos de Agências Executoras Federais

3) Os Orçamentos das Unidades da Federação

4) Os Recursos geridos pelas Agências Reguladoras

Os orçamentos ministeriais com maiores dispêndios para Ciência e Tecnologia são Ministério da Educação e MCTI.

Outra fonte de financiamento é a dos Fundos alimentam o Sistema de Inovação, "tem origem em receitas advindas da arrecadação de impostos, não possuindo qualquer vinculação com destinação delas, recolhidas ao Caixa Único do tesouro. Por outro lado, 
há receitas vinculadas a fundos especificamente destinados a ações que guardem relação com as atividades de CT\&I (Ciência, Tecnologia e Inovação” (ENCTI 2016, pág. 42).

Os Fundos mais relevantes são descritos abaixo:

- Fundo Nacional de Desenvolvimento Científico e Tecnológico (FNDCT)

○ Governança: MCTI, FINEP, Comitês Gestores dos Fundos Setoriais e demais instâncias decisórias do FNDCT.

○ Fonte: arrecadação em diversos setores econômicos relacionados com os Fundos Setoriais de CT\&I

○ Instrumentos: Subvenção, Empréstimos e Fomento

- Fundo Tecnológico (FUNTEC)

○ Governança: BNDES o Fonte: reversão dos lucros anuais do BNDES.

○ Instrumento: Fomento

- Fundo Amazônia.

○ Governança: BNDES

○ Fonte: doações de investidores externos

○ Instrumento: Fomento

- Fundo para o Desenvolvimento Tecnológico das Telecomunicações (FUNTELL)

- Governança: Ministério das Comunicações

○ Fonte: \% sobre a receita bruta das empresas prestadoras de serviços de telecomunicações e sobre serviços do setor

○ Instrumento: Fomento

Fontes indiretas da inovação também são muito importantes, como a Lei de Informática e a Lei do Bem. A primeira exige uma contrapartida de investimento em inovação face aos incentivos fiscais concedidos pela lei 8248/91. A segunda trata-se de um crédito fiscal sobre os investimentos realizados pelas empresas em inovação tecnológica. 


\subsubsection{A LEI DE INFORMÁTICA}

A Lei de Informática (Lei 8248/91) foi uma iniciativa do governo brasileiro para substituir a então reserva de mercado imposta ao setor pela Lei 7.232/84, por um sistema de incentivos fiscais com a intenção de inserir o Brasil como um competidor no cenário global (MCTI,SEPIN,CGEE,UNICAMP, 2010).

A importância da Lei de Informática vem da contrapartida em investimentos em inovação tecnológica face aos incentivos concedidos (isenções e reduções tributárias).

Tal exigência teve como foco a aproximação do ambiente corporativo ao acadêmico, para produção de tecnologia de interesse nacional e para capacitação por meio da formação de RH de alto nível (CGEE,2010).

Com o fim da reserva de mercado e a substancial redução das alíquotas de importação no início dos anos 90, verificou-se um verdadeiro desmonte da indústria brasileira (ABINEE,2014) com a extinção de vários fabricantes e muitos outros transformando-se em apenas representantes comercias. O governo brasileiro, numa tentativa de conter esta situação, lançou uma nova política industrial para informática estabelecida pela lei 8.248/91, que instituiu incentivos e contrapartidas para o setor (BNDES, 2012).

Basicamente, o incentivo consistia principalmente na isenção do IPI (Imposto sobre Produto Industrializado), e uma redução de até 50\% no valor do IR (Imposto de Renda) devido pela empresa, se comprovado investimentos no igual valor em P\&D. Em 1993, com a Portaria Interministerial do MCT/MICT 101, foi introduzido as definições de agregação de valor para o Processo Produtivo Básico (PPB). Para ter acesso aos incentivos, a empresa deveria realizar ao menos os seguintes processos produtivos, de acordo com a Portaria Interministerial MCT/MCT1 - art. $1^{\circ}$ de 07.04.1993:

a) montagem e soldagem de todos os componentes nas placas de circuito impresso;

b) montagem das partes elétricas e mecânicas, totalmente desagregadas, em nível básico de componentes;

c) integração das placas de circuito impresso e das partes elétricas e mecânicas na formação do produto final, montadas de acordo com os itens "a" e "b" acima; 
d) gestão da qualidade e produtividade do processo e do produto final, envolvendo, inicialmente, a inspeção de matérias-primas, produtos intermediários, materiais secundários e de embalagem, o controle estatístico do processo, os ensaios e medições e a qualidade do produto final, ressalvado o atendimento ao disposto no art. $2^{\circ}$ desta Portaria.

Atualmente, a isenção do IPI segue uma tabela decrescente de acordo com percentuais também decrescentes para investimento em P\&D sobre o faturamento de produtos incentivados. Uma diferenciação quanto a localização das empresas também foi inserida. Temos assim, uma tabela para empesas situadas nas regiões Sul e Sudeste e outra para as demais regiões.

Os valores de investimento em P\&D também passaram a exigir aplicações em centros de pesquisas públicas, bem como no Fundo Nacional de Desenvolvimento Científico FNDCT. A figura abaixo sintetiza esses investimentos:

\section{Tabela 3 - Regra de Investimentos em P\&D - Lei de Informática}

\begin{tabular}{|c|c|c|c|c|c|}
\hline \multicolumn{5}{|c|}{ Distribuição de investimentos em P\&D até 2029} & Total \\
\hline \multicolumn{4}{|c|}{$\begin{array}{l}\text { Realizados internamente pela Própria Empresa ou Contratados com terceiros, incluso Institutos } \\
\text { de Pesquisa em qualquer parte do Brasil (Máximo) }\end{array}$} & $2,16 \%$ & \multirow{5}{*}{$4,00 \%$} \\
\hline \multirow{4}{*}{$\begin{array}{l}\text { Investimentos Externos } \\
\text { (Minimos) }\end{array}$} & \multicolumn{2}{|c|}{$\begin{array}{l}\text { Inciso I - Convênio com institutos de pesquisa de } \\
\text { qualquer parte do Brasil }\end{array}$} & $0,80 \%$ & \multirow{4}{*}{$1,84 \%$} & \\
\hline & \multirow{2}{*}{$\begin{array}{l}\text { Inciso II - Convênio com } \\
\text { institutos de pesquisa do } \\
\text { Norte (exceto ZFM), } \\
\text { Nordeste ou Centro- } \\
\text { Oeste (credenciados pelo } \\
\text { CATI) }\end{array}$} & $\begin{array}{l}\text { Entidades públicas ou } \\
\text { privadas }\end{array}$ & $0,45 \%$ & & \\
\hline & & $\begin{array}{l}\text { Exclusivo para Entidades } \\
\text { públicas }\end{array}$ & $0,19 \%$ & & \\
\hline & \multicolumn{2}{|l|}{ Inciso III - FNDCT } & $0,40 \%$ & & \\
\hline
\end{tabular}

Fonte: http://leidainformatica.com/a-lei-de-informatica/

A adesão das empresas ao programa de incentivos da Lei de Informática teve um expressivo crescimento em sua primeira década. Os investimentos oriundos das obrigações legais também tiveram uma resposta correlata ao desempenho do setor no período, alcançando um aporte total de mais de $\mathrm{R} \$ 1,5$ bilhões em 2013 para ser investido em P\&D. A evolução desses aportes pode ser visualizada no Gráfico 8 abaixo: 


\section{Gráfico 5 - Aportes Lei de Informática}

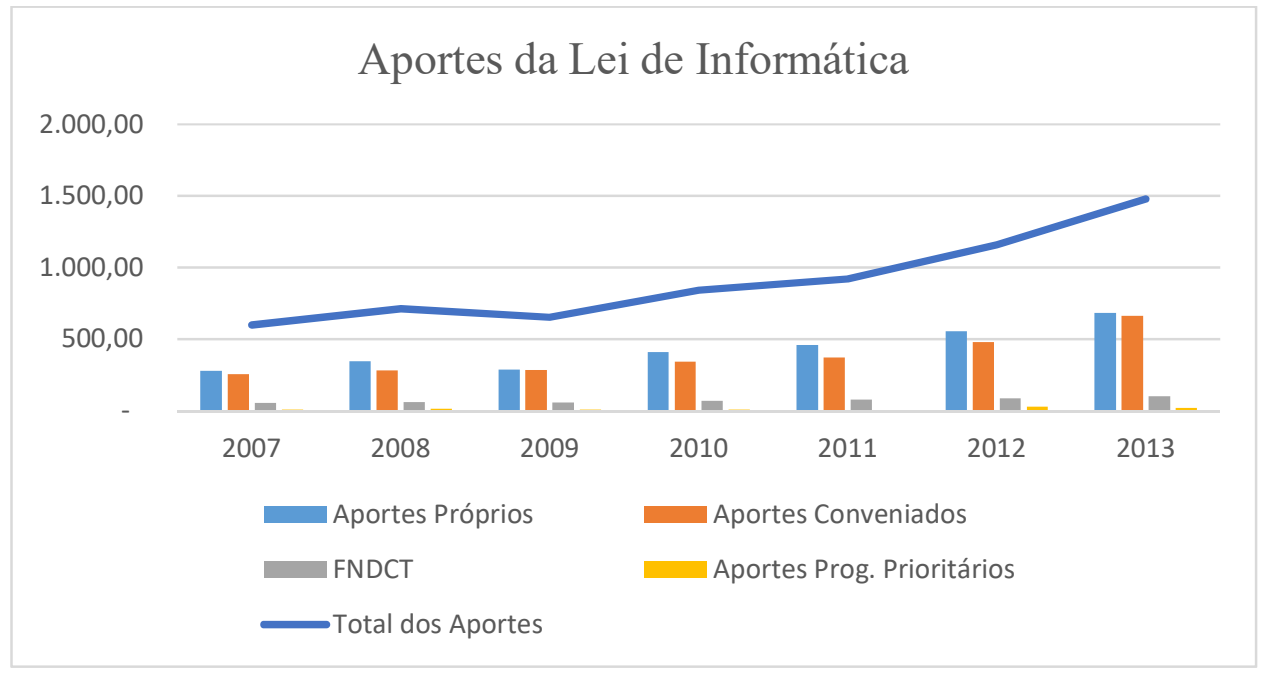

Fonte: Elaborado pelo autor.

\subsubsection{SOBRE A LEI DE INOVAÇÃO E FUNDAMENTO LEGAL}

O interesse para o desenvolvimento de estruturas dedicadas à pesquisa e inovação permeia todas as esferas governamentais, seja em âmbito federal, estadual e mesmo municipal.

Nossa própria Carta Magna já predispôs em seu artigo 218, que "o Estado promoverá e incentivará o desenvolvimento científico, a pesquisa e a capacitação tecnológicas".

Em 2004, temos a promulgação de um importante marco legal: a lei 10.973/04. Conhecida como "Lei da Inovação" (LI), que nos dizeres do Ministério da Ciência e Tecnologia reflete a necessidade do país contar com dispositivos legais eficientes que contribuam para o delineamento de um cenário favorável ao desenvolvimento científico, tecnológico e ao incentivo à inovação.

A lei está organizada em torno de três grandes eixos:

1. Constituição de ambiente propício às parcerias estratégicas entre as universidades, institutos tecnológicos e empresas. 
2. Estimulo à participação de instituições de ciência e tecnologia no processo de inovação.

3. Incentivo à inovação na empresa.

A figura do ICT está presente nestas vertentes como veículo de desenvolvimento tecnológico podendo mesmo prestar serviços de consultoria especializada em atividades desenvolvidas no âmbito do setor produtivo.

\subsubsection{SOBRE A LEI DO BEM}

Contudo, ao tratar da terceira vertente, a LI determina em seu art. 28: “A União fomentará a inovação na empresa mediante a concessão de incentivos fiscais com vistas na consecução dos objetivos estabelecidos nesta Lei".

Como fruto do art. 28 da LI, em novembro de 2005, foi sancionada a Lei 11.196, também conhecida como Lei do Bem (LDB). Em seu capítulo 3º, artigos 17 a 26, a LDB trata especificamente dos Incentivos à Inovação Tecnológica.

O decreto 5798/06 regulamenta os incentivos fiscais para as atividades de pesquisa tecnológica e desenvolvimento de inovação tecnológica que tratam a LDB.

As definições legais de inovação e das atividades de pesquisa e desenvolvimento de foram então estabelecidas:

I - inovação tecnológica: a concepção de novo produto ou processo de fabricação, bem como a agregação de novas funcionalidades ou características ao produto ou processo que implique melhorias incrementais e efetivo ganho de qualidade ou produtividade, resultando maior competitividade no mercado;

II - pesquisa tecnológica e desenvolvimento de inovação tecnológica, as atividades $d e:$

a) pesquisa básica dirigida: os trabalhos executados com o objetivo de adquirir conhecimentos quanto à compreensão de novos fenômenos, com vistas ao desenvolvimento de produtos, processos ou sistemas inovadores; 
b) pesquisa aplicada: os trabalhos executados com o objetivo de adquirir novos conhecimentos, com vistas ao desenvolvimento ou aprimoramento de produtos, processos e sistemas;

c) desenvolvimento experimental: os trabalhos sistemáticos delineados a partir de conhecimentos pré-existentes, visando a comprovação ou demonstração da viabilidade técnica ou funcional de novos produtos, processos, sistemas e serviços ou, ainda, um evidente aperfeiçoamento dos já produzidos ou estabelecidos;

d) tecnologia industrial básica: aquelas tais como a aferição e calibração de máquinas e equipamentos, o projeto e a confecção de instrumentos de medida específicos, a certificação de conformidade, inclusive os ensaios correspondentes, a normalização ou a documentação técnica gerada e o patenteamento do produto ou processo desenvolvido; $e$

e) serviços de apoio técnico: aqueles que sejam indispensáveis à implantação e à manutenção das instalações ou dos equipamentos destinados, exclusivamente, à execução de projetos de pesquisa, desenvolvimento ou inovação tecnológica, bem como à capacitação dos recursos humanos a eles dedicados;

Os incentivos fiscais estão da seguinte forma elencados:

- $\quad$ deduções de Imposto de Renda e da Contribuição sobre o Lucro Líquido CSLL de dispêndios efetuados em atividades de P\&D;

- $\quad$ a redução do Imposto sobre Produtos Industrializados - IPI na compra de máquinas e equipamentos para $\mathrm{P} \& \mathrm{D}$

- $\quad$ depreciação acelerada desses bens;

- $\quad$ amortização acelerada de bens intangíveis;

- $\quad$ redução do Imposto de Renda retido na fonte incidente sobre remessa ao exterior resultantes de contratos de transferência de tecnologia (revogado pela MP 497, de 27 de julho de 2010);

- $\quad$ isenção do Imposto de Renda retido na fonte nas remessas efetuadas para o exterior destinada ao registro e manutenção de marcas, patentes e cultivares;

A utilização dos benefícios depende exclusivamente da decisão da empresa. Uma característica fundamental da LDB é seu uso automático. “A sistemática declaratória da fruição de tais incentivos fiscais dispensa a prévia formalização de pedido e aprovação dos projetos de P\&D pelo MCTI, cabendo ao contribuinte concluir se ele cumpre ou não 
os requisitos previstos na Lei $n^{\circ} 11.196 / 2005$. A partir dai ele, de maneira, automática, elabora sua contabilidade usando ou não os benefícios, vez que não compete ao MCTI aprovar ou reprovar os projetos das empresas"(DEPINÉ et al., 2011)

Esta característica é de extrema importância, basicamente por duas grandes razões, mantém o benefício em fase com a execução do projeto e protege a confidencialidade do mesmo, uma vez que as informações estratégicas ficam em poder das empresas.

Embora ainda muito tímida, a LDB vem aumentando sua adesão ao passar dos anos. $\mathrm{O}$ total de renúncia nestes últimos 10 anos já ultrapassa os $\mathrm{R} \$ 10$ bilhões de Reais.

\section{Gráfico 6 - Utilização da Lei do Bem}

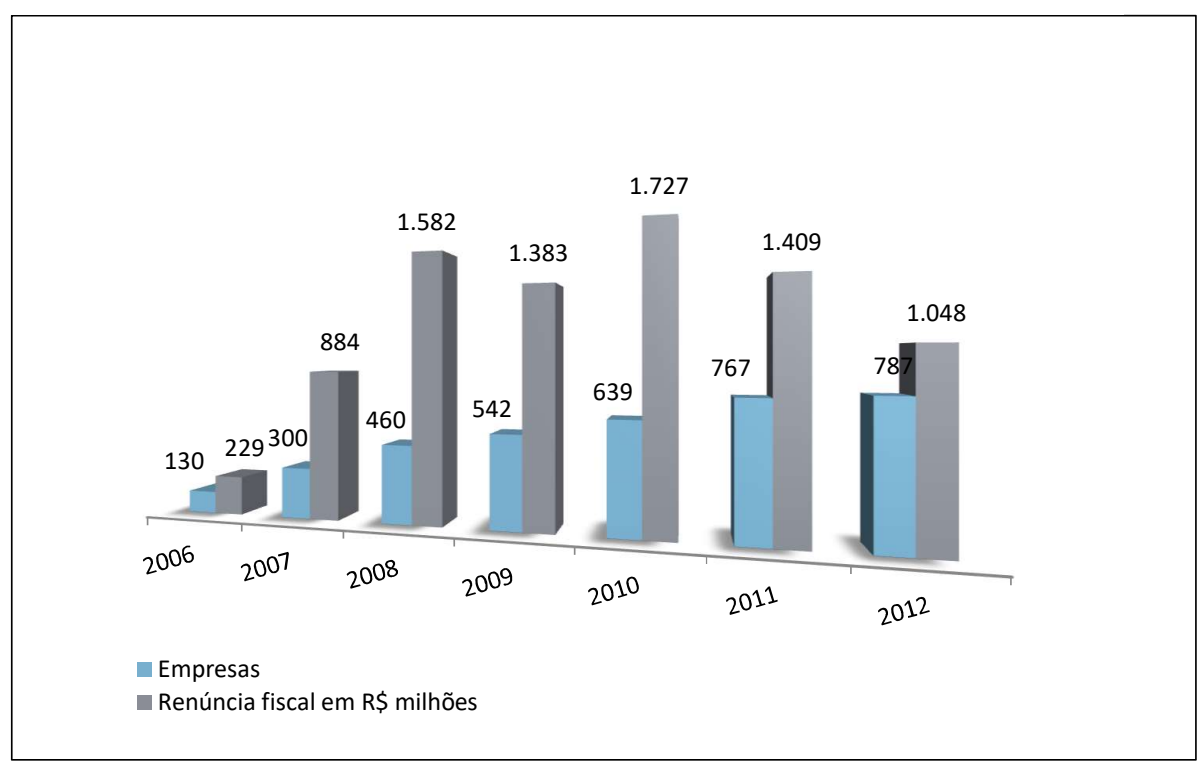

Fonte: Elaborado pelo autor

Ao verificarmos a renúncia físcal obtida através dos anos, os resultados são muito interessantes. Nos vários setores da economia, a LDB trouxe uma renúncia fiscal para a empresa da ordem de $20 \%$ em relação aos dispêndios enquadrados.

A partir do Relatório sobre a Utilização dos Incentivos Fiscais (MCTI) abstraímos os seguintes dados: 
Tabela 4 - Utilização da Lei do Bem

\begin{tabular}{llll} 
Setor & Enquadramento & Renúncia & $\%$ \\
\hline Agroindústria & $91.092,91$ & $18.112,04$ & $19,88 \%$ \\
Alimentos & $225.567,93$ & $44.849,77$ & $19,88 \%$ \\
Bens de Consumo & $441.260,34$ & $91.877,28$ & $20,82 \%$ \\
Construção Civil & $91.876,21$ & $18.267,79$ & $19,88 \%$ \\
Eletroeletrônica & $484.053,79$ & $97.288,03$ & $20,10 \%$ \\
Farmacêutica & $499.123,88$ & $99.241,01$ & $19,88 \%$ \\
Mecânica/ Transp & $1.289 .090,13$ & $256.310,32$ & $19,88 \%$ \\
Metalurgia & $172.993,55$ & $34.396,38$ & $19,88 \%$ \\
Mineração & $162.656,16$ & $32.340,99$ & $19,88 \%$ \\
Moveleira & $21.166,06$ & $4.208,46$ & $19,88 \%$ \\
Papel e Celulose & $50.579,47$ & $10.056,74$ & $19,88 \%$ \\
\hline Petro / Química & $408.422,33$ & $81.401,26$ & $19,93 \%$ \\
Software & $349.445,15$ & $69.487,67$ & $19,89 \%$ \\
Telecomunicação & $7.968,46$ & 1584,37 & $19,88 \%$ \\
Têxtil & $8.285,29$ & 1647,37 & $19,88 \%$ \\
\hline Outras Indústrias & $916.310,32$ & $187.128,81$ & $20,42 \%$ \\
\hline
\end{tabular}

Fonte: Elaborado pelo autor a partir MCTI 2014.

Embora alguns setores tenham uma melhor performance em termos de renúncia, como é o caso do setor farmacêutico e de mecânica, de forma geral o percentual da renúncia sobre o valor do projeto permanece muito equilibrado, em torno de $20 \%$.

\subsubsection{O ARTIGO 19A DA LEI DO BEM}

Vejamos a redação do artigo 19A da Lei 11.196/05 e seus primeiro inciso:

Art. 19-A. A pessoa jurídica poderá excluir do lucro líquido, para efeito de apuração do lucro real e da base de cálculo da Contribuição Social sobre o Lucro Líquido (CSLL), os dispêndios efetivados em projeto de pesquisa científica e tecnológica e de inovação tecnológica a ser executado por Instituição Científica e Tecnológica (ICT), a que se refere o inciso $\mathrm{V}$ do caput do art. $2^{\circ}$ da Lei $\mathrm{n}^{\circ} 10.973$, de 2 de 
dezembro de 2004, ou por entidades científicas e tecnológicas privadas, sem fins lucrativos, conforme regulamento.

$\S 1^{\circ}$ A exclusão de que trata o caput deste artigo:

I - corresponderá, à opção da pessoa jurídica, a no mínimo a metade e no máximo duas vezes e meia o valor dos dispêndios efetuados, observado o disposto nos $\S \S 6^{\circ}$, $7^{\circ}$ e $8^{\circ}$ deste artigo

Quis o legislador através deste instrumento conceder um incentivo especial para os projetos de inovação desenvolvidos de forma colaborativa com ICT ou entidades científicas privadas. $\mathrm{O}$ inciso primeiro nos diz que a exclusão adicional poderá chegar até duas vezes e meia o valor dos dispêndios efetuados, o que corresponde em termos de renúncia $85 \%$ do valor do dispêndio.

Vejamos uma comparação com a tabela 5 abaixo:

Tabela 5 - Comparação da Renúncia entre os níveis de exclusão

\begin{tabular}{|c|r|r|r|r|}
\hline & SEM LDB & LDB 60\% & LDB 80\% & LDB 250\% \\
\hline Dispêndios com Inovação & $1.000 .000,00$ & $1.000 .000,00$ & $1.000 .000,00$ & $1.000 .000,00$ \\
\hline Lucro antes do IR & $5.000 .000,00$ & $5.000 .000,00$ & $5.000 .000,00$ & $5.000 .000,00$ \\
\hline Exclusão Adcional & & $600.000,00$ & $800.000,00$ & $2.500 .000,00$ \\
\hline Base de Cálculo & $5.000 .000,00$ & $4.400 .000,00$ & $4.200 .000,00$ & $2.500 .000,00$ \\
\hline IR 25\% & $1.250 .000,00$ & $1.100 .000,00$ & $1.050 .000,00$ & $625.000,00$ \\
\hline CSSL 9\% & $450.000,00$ & $396.000,00$ & $378.000,00$ & $225.000,00$ \\
\hline Total de Impostos & $1.700 .000,00$ & $1.496 .000,00$ & $1.428 .000,00$ & $850.000,00$ \\
\hline Renúncia & & $204.000,00$ & $272.000,00$ & $850.000,00$ \\
\hline \% / Projeto & & $\mathbf{2 0 , 4 0 \%}$ & $\mathbf{2 7 , 2 0 \%}$ & $\mathbf{8 5 , 0 0 \%}$ \\
\hline
\end{tabular}

Fonte: Elaborado pelo autor.

Outra vantagem apresentada por este artigo consiste, diferentemente do modo convencional onde a fruição do incentivo é automática, neste a avaliação do projeto pela Receita Federal ocorre antes de sua execução, fato que extingue possibilidade de questionamento futuros pela própria Receita Federal sobre a utilização do benefício. 
Desta forma, de modo geral, segundo Fernandes (2006) a lei de inovação pretendeu fomentar as atividades de inovação tecnológica através de três ações: a constituição de ambiente propício às parcerias estratégicas entre as universidades, institutos tecnológicos e empresas o estímulo à participação de institutos de ciência e tecnologia no processo de inovação e o estímulo à inovação nas empresas.

Neste contexto, parece-nos importante a constituição de um ICT privado dentro da Universidade de São Paulo, apto a conectar empresas e a universidade provendo um estímulo fundamental através de renúncia fisscal pela Lei do Bem. 


\section{METODOLOGIA}

De acordo com Hair (HAIR, J; et al., 205) a "pesquisa em administração é uma função de busca da verdade que reúne, analisa, interpreta e relata informações de modo que as decisões administrativas se tornem mais eficazes (pg. 31)".

A ciência, nada mais é que o conhecimento que se tem sobre um determinado assunto. $\mathrm{O}$ método científico é aquele processo que os pesquisadores utilizam para adquirir esse conhecimento. Desta forma, a pesquisa em administração aplicada é motivada por uma tentativa de resolver um determinado problema enfrentado por uma certa organização (HAIR, J; et al., 205).

Figura 9 - Processo de Pesquisa Básica em Administração
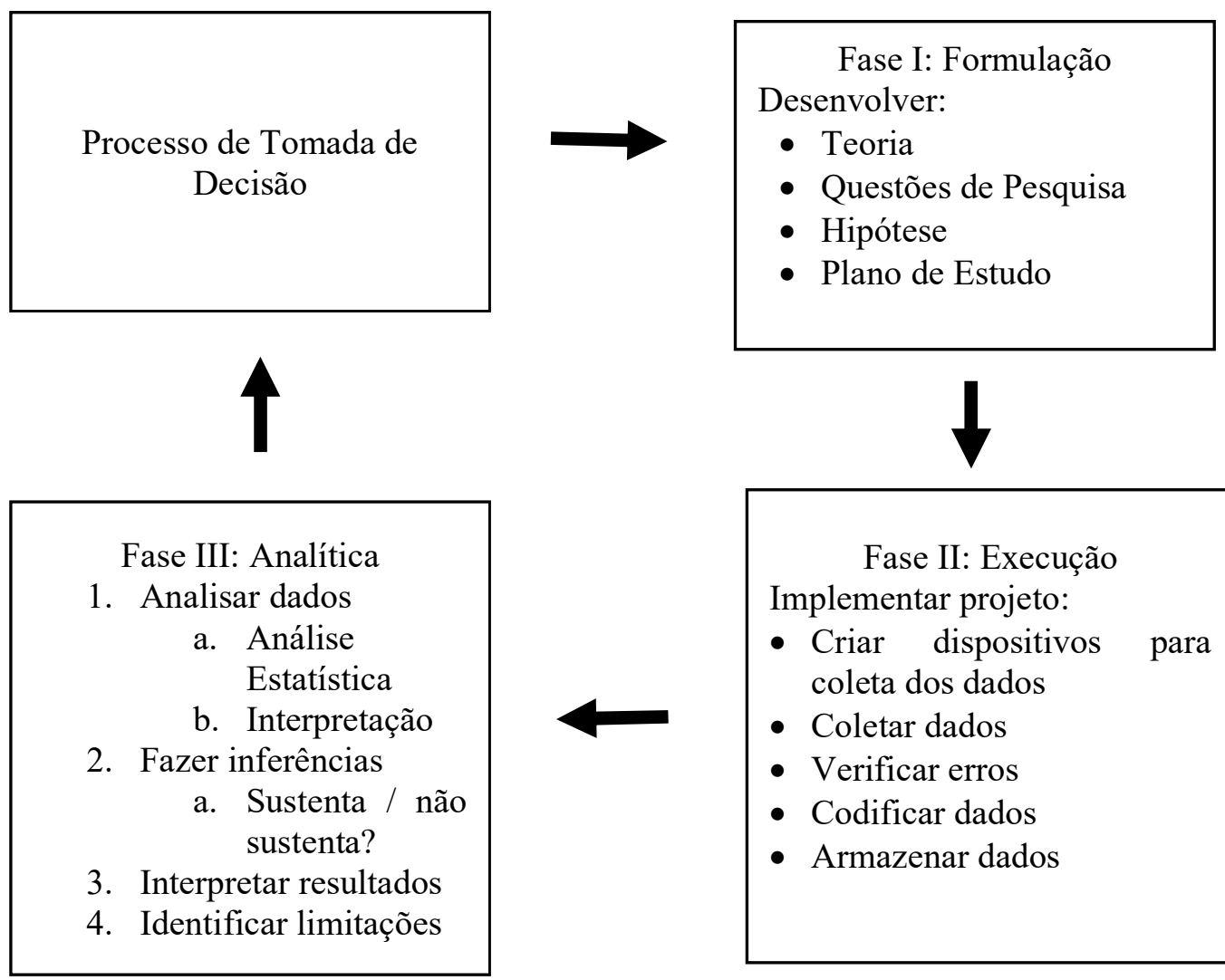

Fonte: HAIR, J. et al.; 2005, pág 76) 


\section{1 - Processo de Tomada de Decisão}

Levando-se em consideração o Programa de Mestrado Profissional, que aplica a Teoria de Aprendizagem Experimental (KRAKAUER; MARQUES e ALMEIDA, 2015) onde o conhecimento parte da prática anterior do pesquisador para a teoria.

“A aprendizagem experiencial proporciona uma visão diferenciada dos processos tradicionais baseados em uma epistemologia racional ou unicamente empírica, sendo o processo pelo qual o conhecimento é gerado a partir da transformação da experiência.”(KRAKAEUR; MARQEUES e ALMEIDA, 2015 pág.5).

Segundo KRAKAUER (2015 pág. 5), "a aprendizagem ocorre não apenas da experiência, mas sim da reflexão sobre a mesma e da resolução de conflitos entre o abstrato e o concreto e entre a ação e a reflexão.” Esse processo pode ser observado na Figura 11 abaixo.

Figura 10 - Ciclo da pesquisa no mestrado profissional em empreendedorismo

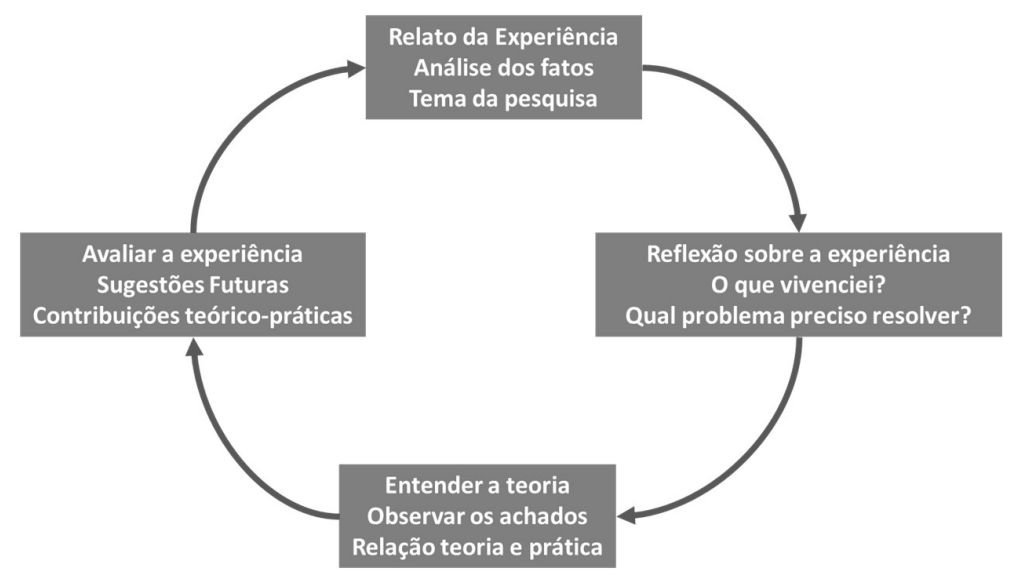

Fonte: KRAKAUER et al. 2015, pág. 8)

Durante o curso do Programa de Mestrado Profissional em Empreendedorismo da Faculdade de Administração, uma visita realizada juntamente com o Coordenador do Programa, Prof. Dr. Marinho Isnard de Almeida, à uma área dentro da Cidade Universitária propiciou a hipótese de se estudar os ambientes de inovação especializados. 
Logo em seguida, juntamente com a orientadora deste trabalho, Profa. Dra. Luciane Meneguin Ortega, decidimos por estudar este tema que tem grande relevância no ecossistema de inovação.

Para desenvolver os estudos, partindo do modelo TAE, optamos pelo método de pesquisa qualitativa, que segundo MYERS (1997) “foram desenvolvidos nas ciências sociais para permitir que os pesquisadores estudem fenômenos sociais e culturais. Exemplos de métodos qualitativos são a pesquisa-ação, pesquisa de estudo de caso e etnografia".

Tendo em vista a possibilidade aberta pelo Coordenador da Agência USP de Inovação, Prof. Dr. Vanderlei Bagnato, de aproveitar os estudos e aplicá-los na concepção do Núcleo do Parque Tecnológico da USP, optamos pelo método da pesquisa-ação, que segundo Thiollent (1986), “a pesquisa-ação é um tipo de pesquisa com base empírica que é concebida e realizada em estreita associação com uma ação ou com a resolução de um problema coletivo e no qual os pesquisadores e os participantes representativos da situação ou do problema estão envolvidos de modo cooperativo ou participativo" (pág.12).

Ainda segundo Thiollent, a pesquisa-ação é uma estratégia metodológica da pesquisa social na qual:

a) "há uma ampla e explícita interação entre pesquisadores e pessoas implicadas na situação investigada; ·

b) desta interação resulta a ordem de prioridade dos problemas a serem pesquisados e das soluções a serem encaminhadas sob forma de ação concreta;

c) O objeto de investigação não é constituído pelas pessoas e sim pela situação social e pelos problemas de diferentes naturezas encontrados nesta situação;

d) O objetivo da pesquisa-ação consiste em resolver ou, pelo menos, em esclarecer os problemas da situação observada;

e) há, durante o processo, um acompanhamento das decisões, das ações e de toda a atividade intencional dos atores da situação; 
f) a pesquisa não se limita a uma forma de ação (risco de ativismo): pretende-se aumentar o conhecimento dos pesquisadores e o conhecimento ou o "nível de consciência das pessoas e grupos considerados.” (THIOLLEN, 1986 pág. 16).

\subsection{Fase I - Formulação}

Ainda de acordo com Hair (2005) a pesquisa exploratória é útil quando as questões de pesquisa são vagas ou quando há pouca teoria para orientar as previsões.

Muito embora os Parques Tecnológicos no Brasil tem sido instalados desde os anos 90, a cidade de São Paulo ainda não teve essa experiência, seu projeto ainda permanece em fase de implantação.

Assim sendo, o autor propõe a utilização das seguintes técnicas de intervenção da pesquisa exploratória para a coleta de dados:

\section{1) Entrevistas Não Estruturadas}

Uma entrevista não estruturada é conduzida sem o uso de uma sequência de perguntas utilizada para uma área relativamente inexplorada. Hair (2005) explica que ela normalmente é utilizada para obter uma compreensão maior das questões críticas envolvidas possibilitando ao pesquisador definir melhor o problema de pesquisa.

Nesta fase, o autor realizará uma série de entrevistas com empresas de setores que reconhecidamente investem em inovação.

As empresas que aceitaram participar destas entrevistas foram:

- Empresa \#1: Empresa Norte Americana, líder mundial na fabricação de hardware para conectividade de redes de internet.

- Empresa \#2: Empresa Alemã, líder mundial em software para gestão. 
- Empresa\#3: Empresa Brasileira, com presença em mais de 20 países, especializada em serviços digitais.

\section{2) Entrevistas em Profundidade}

Uma entrevista em profundidade é uma sessão de discussão individual nãoestruturada entre um entrevistador treinado e um entrevistado (HAIR, 2005). Nestas entrevistas coleta-se dados qualitativos que são obtidos de forma narrativa.

Estas entrevistas serão feitas com atores do sistema de inovação, a partir da modelagem da tríplice hélice de ETZKOWITZ (2000), quais sejam, governo, universidade, empresa.

- Universidade: através do Núcleo de Inovação Tecnológica da Universidade de São Paulo (NIT)

- Governo: através do Ministério da Ciência e Tecnologia e Inovação com o núcleo de incentivo fiscal.

- Empresas: Um grupo selecionado de empresas que possuem programas de inovação.

3) Levantamento bibliográfico sobre Sistemas de Inovação

4) Coleta e levantamento de Dados Primários

5) Coleta e levantamento de Dados Secundários

O framework na figura 11 abaixo visualiza o esquema metodológico a ser seguido. 


\section{Figura 11 - Framework Metodológico}
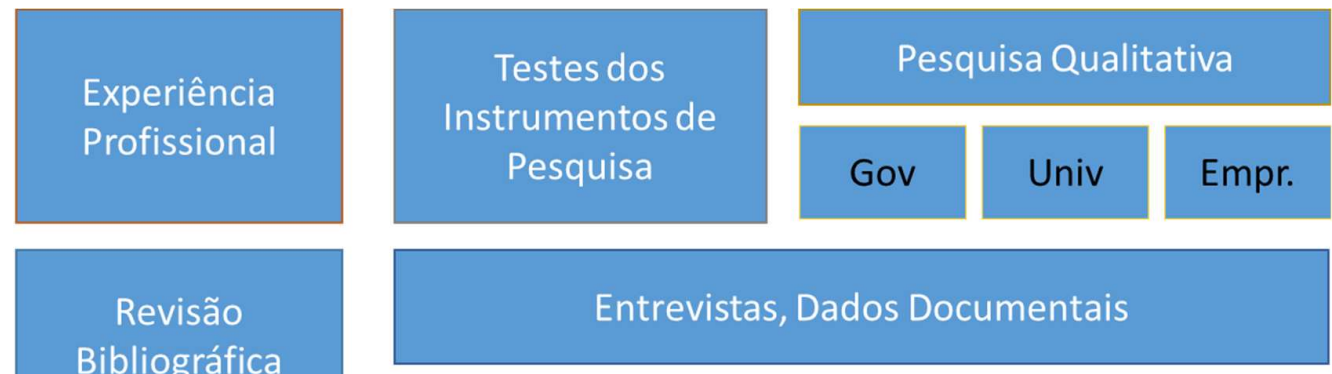

Revisão

Entrevistas, Dados Documentais

\section{Bibliográfica}

Dados Pesquisas

e Leis

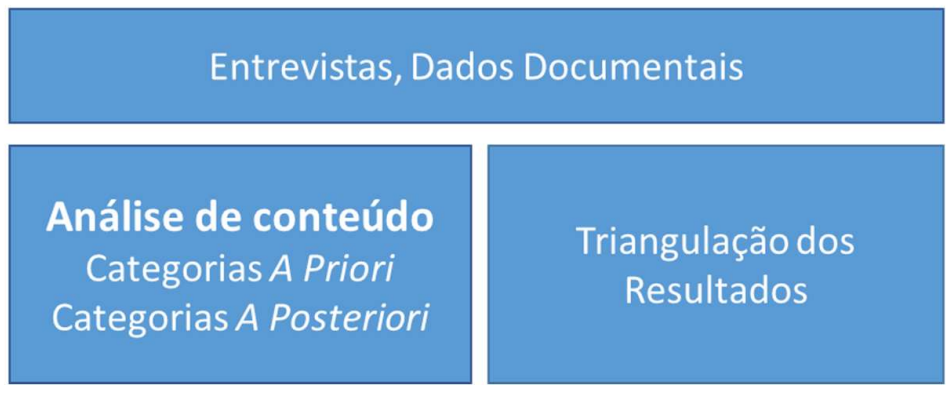

Fonte: Elaborado pelo autor.

\subsection{Fase II: Execução}

Para a Fase de execução que corresponde, segundo a metodologia de Hair, na implementação do projeto. As principais ações nesta fase são as seguintes:

- Criar dispositivos para coleta dos dados

- Coletar dados

- Verificar erros

- Codificar dados

- Armazenar dados

Na pesquisa-ação o planejamento, segundo THIOLLENT (1986), é muito flexível. "Contrariamente a outros tipos de pesquisa, não se segue uma série de fases rigidamente ordenadas. (...) Entre a 'fase exploratória' e a fase de 'divulgação dos resultados', os temas intermediários não foram ordenados numa determinada sequência temporal, pois há um constante vaivém entre as preocupações de organizar um seminário, escolher um tema, colocar um problema, coletar dados, colocar outro problema, cotejar o saber formal dos especialistas com o saber informal dos 'usuários'(..). Preferimos apresentar o ponto 
de partida e o ponto de chegada, sabendo que, no intervalo haverá uma multiplicidade de caminhos a serem escolhidos em função das circunstâncias. " (pág. 47).

\subsubsection{O Ponto de Partida}

A jornada metodológica de captura de informações teve seu início no dia 25/05/2015, quando da apresentação do "Objeto de Pesquisa" na disciplina "Plano de Intervenção" ministrada pelo Prof. Dr. Martinho Isnard de Almeida no Programa de Mestrado Profissional em Empreendedorismo da Faculdade de Administração da Universidade de São Paulo.

Ao relatar o Sistema de Inovação Brasileiro e os incentivos fiscais para inovação em ambientes especializados, o Prof. Martinho questionou sobre a viabilidade de replicarmos esta teoria dentro da Universidade.

No dia subsequente (26/05/2015), o Prof. Martinho levou-nos para conhecer uma área dentro da Cidade Universitária, composta por dois prédios inacabados numa área de $20.000 \mathrm{~m} 2$.

$\mathrm{Na}$ figura 12 abaixo é possível visualizar os prédios da Área II do IPEN e a figura 13 a posição geográfica da Área II do IPEN.

\section{Figura 12 - Prédios da Área II do IPEN}

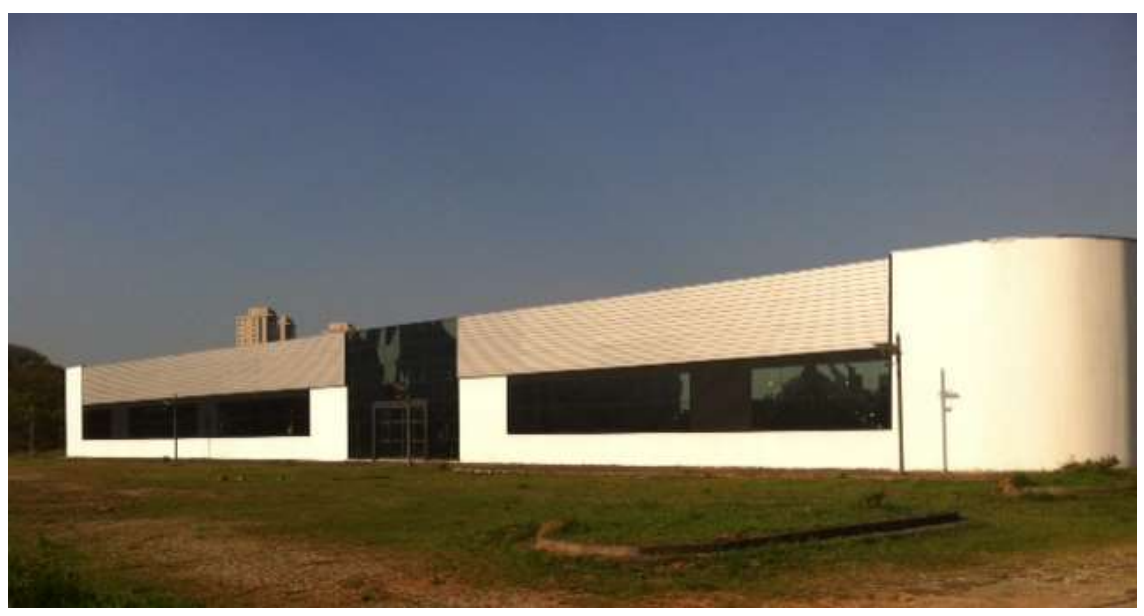

Fonte: Elaborado pelo autor. 


\section{Figura 13 - Area II do IPEN}

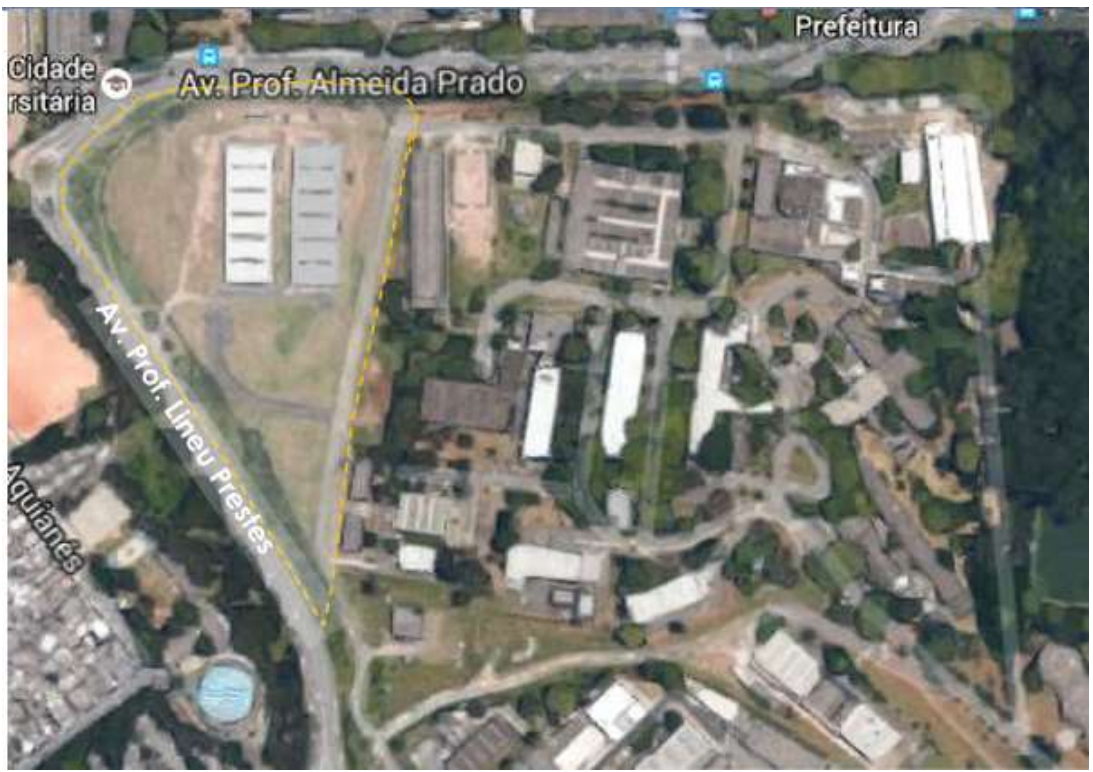

Fonte: Stepahn Steyer Arquitetos (2015, pág 3).

\subsection{2 - Definição de Escopo e Objetivos}

As primeiras reuniões para definir os perímetros dos estudos e da modelagem do projeto foram realizadas com a Vice-Coordenadora da AUSPIN, Profa. Luciane Meneguin Ortega.

A primeira etapa seria construir a base de um modelo de Parque Tecnológico que pudesse servir de apoio para a aplicação prática da área II, posteriormente.

As bases conceituais deveriam seguir a seguintes premissas de Gestão e Governança:

a) Deveria englobar todos os atores da inovação:

a. Governo: Agências de Apoio e Fomento, Laboratórios públicos.

b. Universidades: em nosso caso o ecossistema da USP.

c. Empresas: Empresas âncoras para proporcionar atratividade ao empreendimento, empresas financeiras como fundos de venture captures ou outros fundos de investimentos; 
b) O ambiente deveria ser capaz de prever e promover a produção de conhecimento de base tecnológica através de spin-offs ou startups.

c) Comitê de gestão, onde não só a universidade participasse, mas também as empresas âncoras e os fundos de venture capitals.

A figura 13 abaixo exemplifica o modelo de Gestão e Governança do NPT:

Figura 13 - Gestão e Governança do NPT

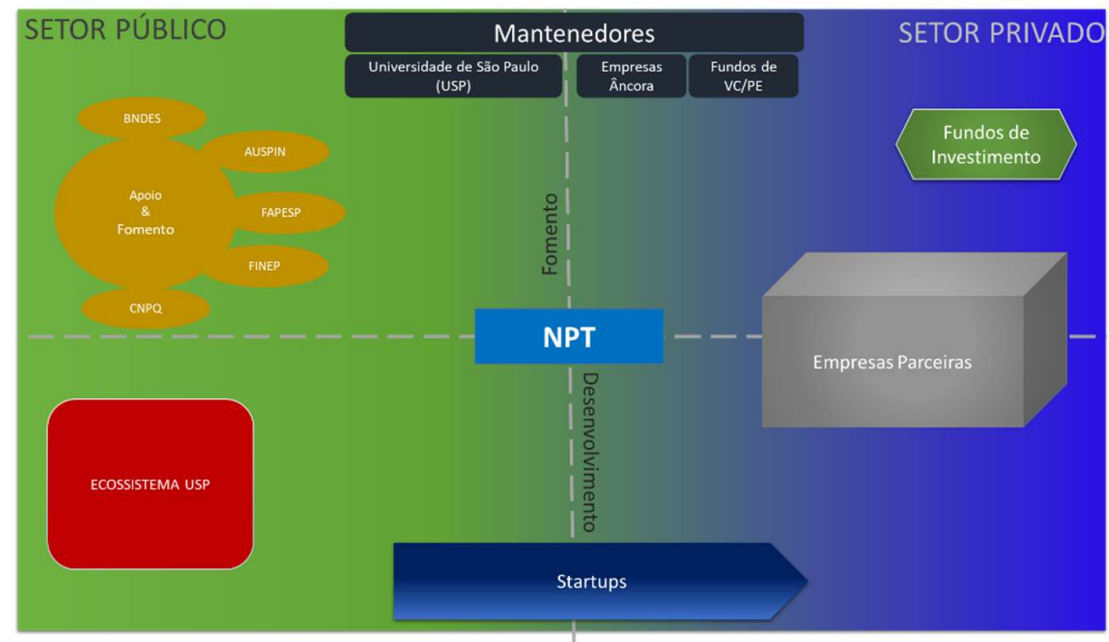

Fonte: Elaborado pelo autor.

\subsubsection{O Vaivém Exploratório}

\section{- 07/09/2015 - Reunião com Coordenador da AUSPIN}

Nesta data tivemos a oportunidade de nos reunir com o Coordenador da Agência USP de Inovação, Prof. Dr. Vanderlei Bagnato e a Vice-Coordenadora Profa. Dra. Luciane Ortega.

O objetivo desta reunião foi discutir as bases de um projeto do Núcleo de Parque Tecnológico através:

a.) Visitar empresas com reconhecido esforço em P\&D para garantir a atratividade do modelo. 
b.) Contratação de um arquiteto para avaliar os investimentos em termos de reformas elétricas e hidráulicas, além de um plano urbanístico a serem feitos na Área II do IPEN.

c.) Estruturar um Estudo de Viabilidade Financeira e identificar modalidades de apoio para financiar o projeto.

Deveras, segundo a ANPROTEC (2008, pág. 16) "um parque tecnológico exige investimentos importantes tanto na sua fase de desenvolvimento como de aperfeiçoamento e inovação. Estes investimentos devem viabilizar os sistemas críticos que asseguram o cumprimento do propósito do empreendimento, envolvendo, basicamente: projeto conceitual do parque, plano de negócios e plano estratégico (...)”.

\section{- Visitas às Empresas para validação de conceito}

Para o desenvolvimento conceitual do modelo, a primeira decisão tomada em termos metodológicos foi realizar visitas à empresas que tem reputação em investimento em P\&D interno e colaborativo. A finalidade destas visitas foi abstrair os principais critérios em termos de atratividade para instalação de um centro de inovação dentro de um Parque Tecnológico.

Tabela 6 - Visita à Empresas e Recursos de Atratividade

\begin{tabular}{|c|c|c|c|c|}
\hline Empresa & Data & $\begin{array}{c}\text { Origem/ } \\
\text { Cargo }\end{array}$ & Setor & Principal Critérios de Atratividade \\
\hline$\# 1$ & $19 / 11 / 15$ & $\begin{array}{c}\text { USA } \\
\text { Diretor }\end{array}$ & Redes de Internet & $\begin{array}{l}\text { - Criação de Ambiente de Inovação } \\
\text { Colaborativa para demonstração de } \\
\text { soluções para clientes. } \\
\text { - Programas de Startups. }\end{array}$ \\
\hline$\# 2$ & $30 / 10 / 15$ & $\begin{array}{c}\text { Alemanha } \\
\text { Diretor }\end{array}$ & Software Gestão & $\begin{array}{l}\text { - Criação de laboratório de inovação para } \\
\text { solução de demandas inovadoras de } \\
\text { clientes. } \\
\text { - Fixação da marca junto à universidade. }\end{array}$ \\
\hline
\end{tabular}

Fonte: Elaborado pelo autor. 
Da mesma forma seria de grande valia a vista à um Parque Tecnológico já implantado para confrontação entre conceito e realidade.

Tal visita ocorreu em 29/10/2015 no Parque Tecnológico da Universidade Federal do Rio de Janeiro.

\section{Figura 15 - Parque Tecnológico da UFRJ}

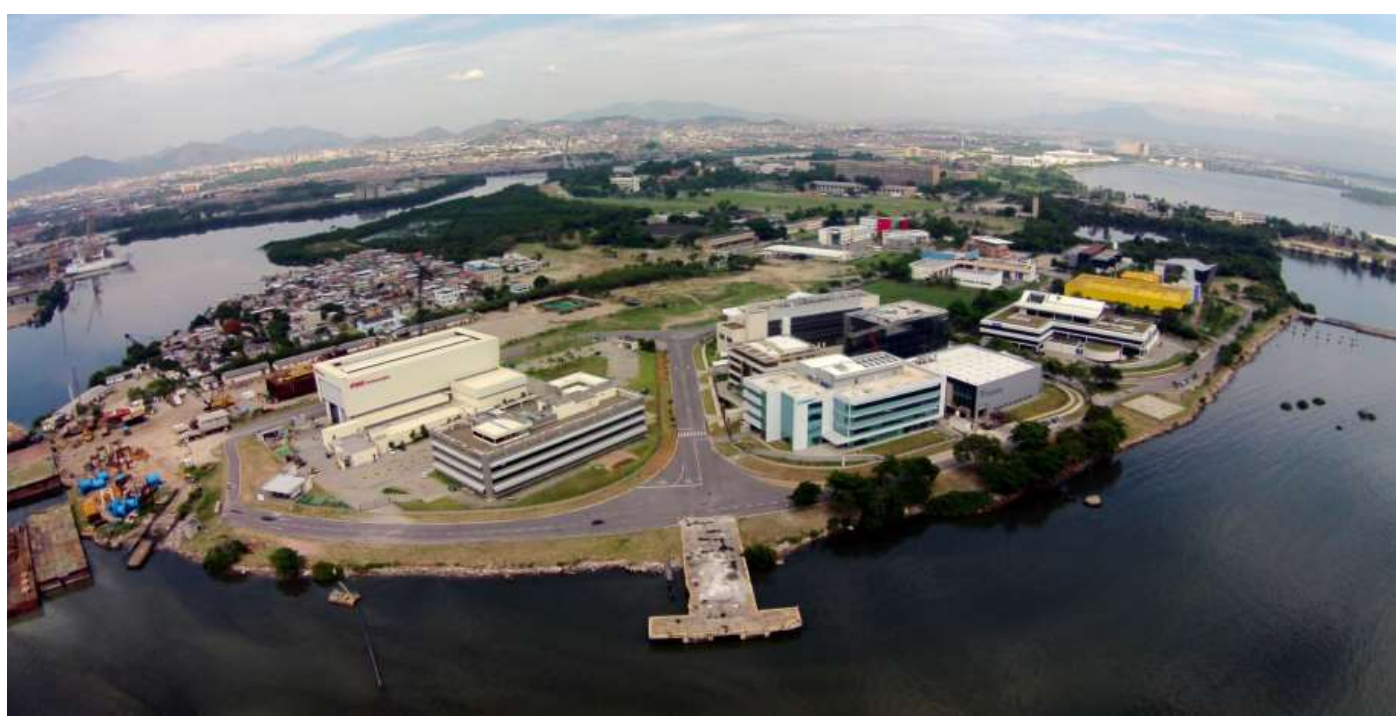

Fonte: Foto de Marcus Almeida/Somafoto

A visita foi realizada com a Sra. Paula Salomão Martins, cujo cargo era de Articulações Corporativas.

Os principais pontos levantados foram:

a. Perfil das Residentes

- Número de Residentes: 56

- 13 Grandes Empresas;

- 29 Startups e

- 7 Pequenas e Médias.

- Número de Empregos diretos

- 189 Doutores

- 342 Mestres

- 1033 Graduados 
As grandes empresas tem interesse em estabelecer-se no Parque Tecnológico em vista dos incentivos obrigatórios em P\&D descritos pela Agência Nacional do Petróleo (ANP). Segundo a Resolução número 33/2005, para os contratos para exploração e produção de petróleo e gás natural, as concessionárias devem investir em $\mathrm{P} \& \mathrm{D}$ o valor equivalente a $1 \%$ da receita bruta gerada. Destes $50 \%$ do total poderá ser investido nas instalações do próprio concessionário.

De acordo com a Sra. Paula S. Martins, os fatores de atratividade do Parque são:

- Incentivos Fiscais

- Federais como a Lei do Bem (11.196/05)

○ Municipais como a Lei 5.344/11, que reduz o Imposto sobre Serviço (ISS) para as empresas instaladas no Parque.

- Serviços Gerais

- Segurança 24 horas;

○ Paisagismo;

○ Limpeza Pública;

- Infraestrutura e manutenção dos espaços;

○ Interação com a UFRJ e poder público;

- Serviço de Articulações Corporativas

- Promoção da interação entre empresas com unidades/grupos de pesquisa da UFRJ;

○ Realização de workshops;

○ Networking;

○ Reuniões de acompanhamento da relação empresa-universidade.

- Serviços Diferenciados

- Serviços básicos de Articulações;

- Diagnóstico de Gestão da Empresa;

- Plano de Inovação e Cooperação com a UFRJ;

○ Acompanhamento dos Planos desenvolvidos;

- Gestão de imagem, assessoria de imprensa, produção de conteúdo;

- Apoio para instalação e infraestrutura. 
- Custos das Áreas Disponíveis

○ Na modalidade de instalação em prédio compartilhado:

- Cessão de Uso $=\mathrm{R} \$ 55,22 / \mathrm{m} 2$

- $\quad$ Taxa de Serviço $=\mathrm{R} \$ 39,27 / \mathrm{m} 2$

- $\quad$ Total $=\mathrm{R} \$ 94,49 / \mathrm{m} 2$

\section{9/10/2015 - Visita Técnica do Arquiteto e Engenheiros}

O escritório de arquitetura especializado em construção de ambientes de inovação Stephan Steyer Arquitetos foi convidado para fazer uma vistoria e apresentar um orçamento para finalização da infraestrutura do terreno e benfeitorias.

O estudo realizado está apresentado no Anexo V.

O resumo dos investimentos necessários para reformar e terminar as obras dos prédios do Anexo II do IPEN podem ser visto na tabela 7 abaixo:

\section{Tabela 7 - Valores de Obra}

ÁREA DO TERRENO: $20.000 \mathrm{~m}^{2}$

Vagas: 187

\begin{tabular}{|l|c|c|}
\hline \multicolumn{1}{|c|}{ Edifício } & Área & Valor da Obra \\
\hline Módulo Oeste & $1.880 \mathrm{~m}^{2}$ & $\mathrm{R} \$ 2.755 .830,34$ \\
\hline Módulo Leste & $1.880 \mathrm{~m}^{2}$ & $\mathrm{R} \$ 2.591 .228,31$ \\
\hline Módulo Administrativo & $1.300 \mathrm{~m}^{2}$ & $\mathrm{R} \$ 4.043 .884,18$ \\
\hline Área externa & $27.480 \mathrm{~m}^{2}$ & $\mathrm{R} \$ 4.971 .519,40$ \\
\hline Área externa (valor mínimo para inicio das obras nos edifícios) & $\mathrm{R} \$ 1.800 .000,00$ \\
\hline
\end{tabular}

VALOR TOTAL

Fonte: Stephan Steyer Arquitetos (20015, pág. 13) - Anexo V 


\section{4/07/2016 - Encontro na AUSPIN para apresentação do modelo conceitual}

Um novo encontro com o Coordenador e Vice-Coordenadora da AUSPIN foi marcado em 04/07/2016 para apresentação e discussão do modelo de adesão ao Núcleo do Parque Tecnológico.

A partir das visitas às empresas e ao Parque Tecnológico da UFRJ foi possível construir um rol de ofertas de serviços e contrapartidas para empresas residentes, bem como a Missão e Objetivos do Núcleo do Parque Tecnológico.

\section{Missão:}

Constituir e gerenciar um Centro de Inovação Colaborativa, com laboratórios estruturados e mantidos pelas empresas parceiras, com foco no desenvolvimento de $\mathrm{P}, \mathrm{D} \& \mathrm{I}$ e programas educacionais em parceria com os diversos laboratórios de pesquisa do ecossistema USP.

\section{Visão:}

- Facilitar a execução de projetos de P,D\&I colaborativos entre as empresas residentes e o ecossistema de inovação da USP

- Facilitar a captura de benefícios fiscais para projetos de P,D\&I das empresas residentes

- Apoiar as empresas residentes na captação de recursos para Inovação (Finep, Fapesp, BNDES...)

- Assessorar as empresas residentes na execução de atividades de recrutamento no ambiente USP

- Desenvolver programas educacionais sob medida para as empresas residentes

- Assessorar as empresas residentes desenvolvimento e gestão de programas de inovação 
Considerando as dimensões relativamente reduzidas da área II do IPEN, o Núcleo do Parque Tecnológico poderia abrigar até 16 empresas em 12 módulos. Um valor por $\mathrm{m}^{2}$ foi estipulado pela concessão do uso do espaço e uma taxa de serviço condominial para suprir as despesas comuns, conforme a tabela 8 abaixo.

Tabela 8 - Custeio dos Módulos

\begin{tabular}{|c|c|c|c|c|}
\hline Módulo & Área & Aluguel & Taxa & V. Mensal \\
\hline Âncora & $250 m^{2}$ & RS 55,00 $\mathrm{m}^{2}$ & $\mathrm{R} \$ 45,00 \mathrm{~m}^{2}$ & R\$ 26.500,00 \\
\hline Master & $200 m_{2}$ & $\mathrm{R} \$ 55,00 \mathrm{~m}^{2}$ & $\mathrm{R} \$ 45,00 \mathrm{~m}^{2}$ & R\$ 20.000,00 \\
\hline Sênior & $100 m^{2}$ & $\mathrm{R} \$ 55,00 \mathrm{~m}^{2}$ & $\mathrm{R} \$ 45,00 \mathrm{~m}^{2}$ & R\$ $10.000,00$ \\
\hline
\end{tabular}

Fonte: Elaborado pelo autor.

Todavia, o interesse da universidade não é a cobrança de valores de ocupação, mas sim o comprometimento das empresas em projetos colaborativos com a universidade.

De acordo com a ANPROTEC (2008, pág. 17) "as empresas inovadoras instaladas em Parques Tecnológicos, devem em princípio apresentar indicadores de destaque no que se refere investimentos em atividades de P\&D.”.

Para tanto, um comprometimento em projetos em itens financiáveis deverá ser solicitado das empresas residentes. Na tabela 9, pode ser visto os valores a ser comprometido em projetos.

Tabela 9 - Comprometimento em Projetos

\begin{tabular}{|l|c|}
\hline \multicolumn{1}{|c|}{ Módulo } & Comprometimento \\
\hline Âncora & R\$ 1.000.000,00 / ano, durante 5 anos \\
\hline Master & R\$ 750.000,00 / ano, durante 05 anos \\
\hline Sênior & $\mathbf{R} \$ 500.000 /$ ano, durante 05 anos \\
\hline
\end{tabular}

Fonte: Elaborado pelo autor. 
O comprometimento de investimento em projetos deverá ser discutido e com a equipe de gestão do parque e de comum acordo selar esses compromissos.

De forma exemplar e não cumulativa um cardápio de itens financiáveis foi desenvolvido para facilitar e direcionar as ações concretas da parceria empresa-universidade. Na tabela 10, podemos encontrar os itens financiáveis para utilização do comprometimento em investimento anual e plurianual da empresa residente.

\section{Tabela 10 - Cardápio de Itens Financiáveis}

\section{Itens Financiáveis}

- Projetos de pesquisas contratados com a USP (Corpos Docente e/ou Discente)

- Contratação de alunos (graduandos ou pós-graduandos) para o laboratório instalado no CIC@USP

- Contratação de capacitação e serviços da USP

- Contratação de consultoria para gestão da inovação e /ou para captação de recursos(CIC@USP)

- Realização de eventos em parceria com o CIC@USP

- Investimento em start ups desenvolvidas no CIC@USP

- Utilização de laboratórios da USP

- Doação de equipamentos, produtos, serviços, licenças de software e demais recursos para USP

- Doação para o fundo de obras e melhorias do CIC@USP e/ou investimentos em infra-estrutura para USP

- Patrocínio de iniciativas USP

- Contratos de licenciamento de tecnologias USP (patentes, software e etc)

- Coorientação de teses e dissertações USP

- Outros projetos de cooperação com a USP

Fonte: Elaborado pelo autor. 
Um rol de serviços especializados será colocado à disposição das empresas residentes, cuja contratação também incorpora a lista de serviços financiáveis. A tabela 11 exemplifica esses serviços.

Tabela 11 - Lista de Serviços Especializados

\begin{tabular}{|l|}
\hline \multicolumn{3}{|c|}{ Serviços Especializados } \\
\hline - Consultoria para revisão/estruturação de programas de \\
inovação \\
- Consultoria para captação de recursos para inovação \\
- Consultoria para planejamento da cooperação com o \\
ecossistema USP \\
- Assessoria para mobilização de recursos e competências USP \\
para atuação em projetos das residentes \\
- Assessoria no desenvolvimento de programas educacionais \\
com focos específicos \\
Facilitação da interação entre empresa e unidades/grupos de \\
pesquisa da USP \\
Realização de de eventos e workshops em temas de interesse \\
das empresas residentes \\
- Networking com foco na integração das residentes do \\
CIC@USP
\end{tabular}

Fonte: Elaborado pelo autor.

A governança do NPT será definida e gerenciada pela USP, tendo como principal ator a AUSPIN. Sua estrutura está distribuída em 03 camadas, a saber:

- Camada Estratégica: Define os objetivos do projeto, supervisiona as atividades do time executivo e emite as orientações estratégicas do NPT.

- Camada Operacional: Traduz as orientações estratégicas da Camada Estratégica em um programa executável. 
- Camada Tática: Implementa as ações necessárias para a realização dos planos estratégico e tático do NPT.

O Professor Bagnato nesta ocasião também solicitou que fosse providenciado uma proposta de constituição e desenvolvimento do Núcleo Parque Tecnológico da USP com a finalidade de apresentar ao Reitor da Universidade e aos órgãos e agências de fomento, com a finalidade de levantar recursos para o início das obras.

A Proposta de Constituição e Desenvolvimento do Núcleo Parque Tecnológico da USP encontra-se no Anexo V.

\section{9/10/2016 - Visita ao Secretário do MCTI em Brasília}

Uma agenda foi definida com o Secretário Nacional de Desenvolvimento Tecnológico e Inovação do MCTI, Prof. Dr. Alvaro Toubes Prata para apresentação da Proposta de Constituição e Desenvolvimento do NPT.

O próprio Coordenador da AUSPI, Prof. Dr. Vanderlei Bagnato participou desta visita em Brasília em 19/10/2016.

Após a apresentação, dando sua aprovação o Secretário solicitou que um ofício fosse enviado para o Sr. Ministro Gilberto Kassab contendo as demandas da AUSPIN para implementação do Projeto Núcleo Parque Tecnológico da Universidade de São Paulo.

O referido ofício foi encaminhado para o Sr. Ministro na data de 21/10/2016, e encontrase no Anexo I (pág. 72).

\section{5/11/2016 - Visita do Secretário Sr. Álvaro Toubes Prata à AUSPIN}

Após a reunião em Brasília, o Sr. Secretário Álvaro Toubes Prata fez uma visita à USP com a finalidade de conhecer melhor os trabalhos desenvolvidos pela AUSPIN e também conhecer os prédios da Área II do IPEN. 
Nesta ocasião, o Sr. Secretário disse que a FINEP seria envolvida para encontrar a melhor forma de financiar o projeto do NPT.

\section{1/05/2017 - Reunião na Subsecretaria de Ciência, Tecnologia e Inovação}

Atendendo a solicitação do Sr. Secretário Álvaro Toubes Prata, o Superintendente Regional da Finep para São Paulo organizou uma reunião na Subsecretaria de Ciência e Tecnologia e Inovação de São Paulo com a presença do Subsecretário Marcelo Strama para definir uma rota de financiamento para o projeto NPT.

Ficou definido que a USP, a Subsecretaria de Inovação e a Finep fariam um investimento para início das obras do NPT, com o objetivo de terminar ao menos um dos prédios do anexo II do IPT.

Para formalizar a solicitação um ofício da AUSPIN foi dirigida ao Sr. Secretário Marcelo Strama.

Este ofício é o anexo II deste trabalho (pág. 74).

\subsection{Ponto de Chegada}

Em 05/06/2017, o Magnífico Reitor da Universidade de São Paulo, Prof. Dr. Marco Antonio Zago através do Ofício de 5 de Junho de 2017 estabelece os termos das discussões acerca do uso das fontes de recursos envolvendo a USP, o MCTI e a Secretaria de Ciência do Estado de São Paulo.

O resumo do uso dos recursos, por fonte, para a instalação do Núcleo do Parque Tecnológico de São Paulo a partir do referido ofício pode ser visto na tabela 12 abaixo. 
Tabela 12 - Resumo do Uso dos Recursos

\begin{tabular}{|l|l|l|}
\hline Origem dos Recursos & Valor (R\$) & \multicolumn{1}{|c|}{ Uso Pretendido } \\
\hline USP & $2.000 .000,00$ & $\begin{array}{l}\text { Conclusão da pavimentação, portaria e } \\
\text { estacionamento dos atuais blocos. } \\
\text { Adaptação do espaço pra abrigar as } \\
\text { empresas específicas } \\
\text { Estabelecimento da equipe de gestão, } \\
\text { governança e formulação da programação } \\
\text { do núcleo. }\end{array}$ \\
\hline Secretaria C\&T SP & $1.000 .000,00$ & $\begin{array}{l}\text { Estabelecimento da estrutura elétrica; } \\
\text { Estabelecimento da estrutura hidráulica; } \\
\text { Pintura e acabamento interno; } \\
\text { Parcial apoio ao início da gestão do } \\
\text { Núcleo. }\end{array}$ \\
\hline MCTIC & $1.000,000,00$ & $\begin{array}{l}\text { Adequação de espaço para gestão e } \\
\text { governança. } \\
\text { Infraestrutura de informática. } \\
\text { Realização da chamada pública para as } \\
\text { empresas. } \\
\text { Parcial apoio ao início da gestão e } \\
\text { governança. }\end{array}$ \\
\hline
\end{tabular}

\section{Carta de Intenção da CAIXA Econômica Federal}

Em 15 de maio de 2017, a Caixa Econômica Federal enviou para a AUSPIN uma "Carta de Intenção" formalizando seu interesse em participar do Projeto Núcleo Parque Tecnológico da Universidade de São Paulo (NPT@USP) como Residente-Cotista Âncora, solicitando a reserva prévia da referida cota.

A Carta de Intenção da CAIXA é o anexo IV deste trabalho (pág. 79).

Ainda em 06/07/2017, uma comissão da CAIXA esteve na AUSPIN para dirimir dúvida, visitar a área e definir os termos contratuais. 


\section{Entrevista com a CAPES - Interação empresa-universidade}

Em paralelo a este tema do NPT, a uma questão importante quanto ao financiamento da inovação através da LdB, é o artigo 19-A que concede até $85 \%$ (oitenta e cinco por cento) em crédito fiscais sobre os dispêndios dos projetos de inovação.

Para compreender esta questão, uma entrevista em profundidade foi realizada com a Dra. Alice Souto Maior - analista científica e tecnológica da Coordenação Geral de Programas Estratégicos da CAPES, por meio telefônico nas seguintes datas, 18/02/2016 e 08/07/2016 e teve por objetivo compreender a utilização da ferramenta de incentivo físcal da Lei do Bem sobre projetos colaborativos entre empresa-universidade.

A- Qual a quantidade de projetos submetidos para apreciação dos projetos de inovação colaborativa no âmbito da Lei do Bem através do dispositivo 19-A?

Resposta: O artigo 19-A da Lei do Bem foi regulamentado pelo decreto 6.260/07, em 20 de novembro de 2007. O edital da CAPES ficou disponível para recepção de projetos até o ano de 2015.

Neste período foram apresentados um total de 230 projetos.

B- Qual a quantidade de projetos aprovados pela comissão julgadora dos projetos colaborativos no âmbito da Lei do Bem através do dispositivo 19-A?

Resposta: Durante o período de vigência do edital CAPES para projetos relacionados com o dispositivo 19-A da Lei do Bem, apenas 38 (trinta e oito) projetos foram aprovados pela comissão interministerial liderada pela CAPES.

C- Qual a quantidade de projetos executados ou em execução no âmbito da Lei do Bem através do dispositivo 19-A?

Resposta: Dos trinta e oito projetos aprovados apenas um único projeto encontra-se em execução. O projeto possui como tema "Segurança e Mobilidade com alta escalabilidade” submetido pelo Prof. Dr. Wilson Vicente Ruggiero - USP.

D- Se a CAPES identificou alguma razão que possa ser qualificada como barreira à interação entre Universidade-Empresa para os projetos no âmbito da Lei do Bem através do dispositivo 19-A? 
As principais razões pela baixa adesão aos incentivos relacionados à projetos interativos Universidade-Empresa na visão da CAPES são:

1) Desconhecimento das empresas acerca deste incentivo;

2) Burocracia dos Institutos de Pesquisa públicos;

3) Processo de submissão dos projetos realizados por professores sem a participação das empresas. 


\section{Análise dos Resultados}

Segundo THIOLLENT (1986, pág.85), “os métodos experimentais comuns, válidos em laboratórios, seriam inadequados na pesquisa em organizações reais. A pesquisa-ação é apresentada como alternativa. Seu princípio fundamental consiste na intervenção dentro da organização na qual os pesquisadores e os membros da organização colaboram na definição do problema, na busca de soluções e, simultaneamente, no aprofundamento do conhecimento científico disponível".

A participação ativa de entre o pesquisador e os membros da organização ficaram evidenciados pela atividade relacional entre os vários atores e esferas institucionais.

Certamente, sem o envolvimento do Coordenador e da Vice-Coordenadora da AUSPIN, do Magnífico Reitor da USP, do Ministro e Secretário do MCTI, da Secretaria de Ciência, Tecnologia e Inovação do Estado de São Paulo e da Superintendência Regional da Finep não seria possível chegar ao êxito deste projeto.

A definição do problema de pesquisa, "como um ambiente especializado em inovação pode estimular a interação entre o setor público, privado e acadêmico", ficou claro com a pesquisa bibliográfica e pela entrevista realizada no Parque Tecnológico da UFRJ.

De acordo com ANPROTEC, os 28 Parques Tecnológicos contabilizam 32,2 mil empregos em 939 empresas residentes.

Segundo o Secretário Executivo do MCTI, Prof. Dr. Alvaro Toubes Prata, "outro dado importante mostrado pela pesquisa foi que, para cada $\mathrm{R} \$ 1,00$ investido pelo governo federal na implantação e consolidação dos parque científicos e tecnológicos, foram capitalizados outros $\mathrm{R} \$ 4,00$ dos governos estaduais e municipais e da iniciativa privada. Esse resultado é altamente significativo, com clara demonstração de que o governofederal etá atuando corretamente no seu papel indutor na impalntação desses habitas de inovação"(in ANPROTEC 2014, pág. 4). 
A inovação é a um drive estratégico numa sociedade de base do conhecimento. $\mathrm{O}$ crescimento quase exponencial de ambientes especializado das últimas décadas desencadeou uma mudança cultural acerca da inovação nas empresas brasileira.

Por outro lado, o processo inovador é essencialmente complexo e incerto, sujeito a falhas e fracassos (BOLY, 2008) e por esta mesma razão, a inovação deve ser incentivada pelo Estado (OCDE, 2005).

O aprimoramento de fontes de financiamento é uma política indutora eficaz. A Lei do Bem tem tido nos últimos anos um forte crescimento, embora seu artigo 19A que trata especificamente dos projetos colaborativos entre universidade-empresa não vingou.

\section{Conclusão}

Por este trabalho vemos que, embora ainda não esteja concluída a intervenção almejada, foi possível demonstrar a interação da universidade com o setor público e privado, como foi proposto no objetivo da pesquisa.

Observamos que o tempo do mestrado não foi suficiente para que se atingisse os resultados completos de uma pesquisa-ação e ter uma avaliação das principais pessoas envolvidas na intervenção. Contudo, pelos documentos apresentados pode-se verificar que o processo de intervenção está caminhando a contento.

Desta forma, embora tenhamos que concluir esta dissertação por questões de prazo regimental, este processo de interação com o setor público e privado será continuado após a defesa da mesma.

A interação universidade-empresa é uma tendência mundial na sociedade do conhecimento. A inovação não é mais vista como um processo fechado, mas embora guardada sua identidade específica de cada empresa, esse é um processo cada vez mais aberto. 
O processo de desenvolvimento da proposta de constituição do Núcleo do Parque Tecnológico da Universidade de São Paulo de forma ativa em conjunto com instituição tão importantes como a AUSPIN, MCTI, FINEP e a Secretária de Ciência e Tecnologia do Estado de São Paulo foi fundamental para a compreensão da importância dos ambientes especializados seja para a empresa, para a universidade como para o governo.

Estar próximo a instituições que produzem conhecimento como as universidades tornase um diferencial competitivo e estratégico, pois reduz-se o time-to-market, o risco tecnológico, acesso a grupos de pesquisa de alto nível, a mão-de-obra qualificada e a incentivos fiscais significativos concedidos para estes ambientes, como é o caso da Lei do Bem em seu artigo 19-A.

Em todas as visitas realizadas nas empresas para apresentação da proposta do NPT, foi possível apreender:

\section{1- Importância do Ambiente de Inovação para o Setor Corporativo}

Nas empresas visitadas, o interesse em poder participar de forma física e perene com a Universidade de São Paulo através do NPT foi unânime.

Seria importante ressaltar o papel protagonista da Agência USP de Inovação AUSPIN neste processo. A Agência é, entre outras atividades, responsável pela política de inovação da universidade, entre elas a transferência de tecnologia e o empreendedorismo, bem como o relacionamento entre a universidade com a sociedade e o mundo corporativo.

Tal situação está consoante com o modelo de inovação aberta utilizado pelas grandes corporações e os centros universitários de primeiro mundo atualmente. $\mathrm{O}$ entendimento que a maior parcela de conhecimento está fora da empresa mudou o tratamento de como gerenciar a inovação através de programas de colaboração universidade-empresa. 
Deveras, as universidades possuem uma finalidade muito clara na geração de conhecimento através de pesquisas básicas e aplicadas, com utilização de laboratórios sofisticados e mão-de-obra bastante qualificada proveniente dos próprios programas de mestrado e doutorado.

A possibilidade das empresas estar presente no NPT, propicia a construção de um plano de interação colaborativa de médio e longo prazo com estes grupos de pesquisas atendendo às necessidades das empresas quanto a objetivos e metas, reduzindo riscos tecnológicos e custos.

O NPT apresenta-se, então não só como um ambiente físico, mas também como um facilitador entre a empresa e o ecossistema uspiano, seja para facilitar a identificação de pesquisadores, contratação de alunos, bem como na própria execução dos projetos de P,D\&I. Esta foi uma característica muito bem avaliada nas entrevistas realizadas.

Outro ponto relevante apresentado pelas empresas visitadas é a associação da marca corporativa com a Universidade de São Paulo consolidando a estratégia de marketing da empresa.

\section{2- Importância dos Incentivos Fiscais}

No contexto da inovação, ferramentas de fomento indiretos, como é o caso da LdB, são importantes veículos para reduzir o custo do investimento em projetos de alto risco.

Quando se trata de inovação, trata-se de risco tecnológico e mercadológico, que se materializa em incertezas quanto ao atingimento de sucesso do projeto, e, portanto, um investimento com poucas garantias de retorno para a empresa.

De forma geral, as empresas visitadas desconheciam os incentivos fiscais para projetos colaborativos com universidades ou institutos de pesquisas. Ao informarmos dos incentivos vinculados ao artigo 19A da Lei do Bem que podem 
chegar até $85 \%$ do valor do projeto inovador em créditos fiscais de forma préaprovada pelas instâncias do governo, a resposta foi muito positiva para projetos de maiores riscos.

Neste sentido, o NPT seria além de um divulgador natural destes incentivos a todas empresas privadas que o procurarem, seria também uma ferramenta acreditada para que elas alcancem tais benefícios.

De acordo com a CAPES, o único projeto que conta com os incentivos do artigo 19-A da LdB em nível nacional é justamente de uma empresa paulista em colaboração com um laboratório da USP.

\section{3- Papel do Governo na Iniciativa do NPT}

Diante do fato que os prédios que irão compor o NPT ainda se encontram incompletos ficou evidenciado o papel fundamental do governo como financiador, pois as empresas buscam instalações prontas já disponíveis. Ou seja, o setor privado não vai financiar a construção física do ambiente.

Esta situação, se repete para quase todos os ambientes de inovação. O governo torna-se a principal fonte de fomento para o desenvolvimento dos ambientes especializados, confirmando o que foi constatado nas entrevistas com a Finep e MCTI. A entrada de empresas privadas nestes ambientes ocorre apenas após a inauguração dos mesmos.

Muito embora o momento vivenciado pelo Governo é de pouca disponibilidade de investimento, esse mostrou-se viável. Pois o investimento das empresas após sua instalação supera o investimento inicial do governo. 


\section{Carta de Intenção da CAIXA}

A adesão de uma empresa com o porte e dimensão da CAIXA Econômica Federal ao projeto foi recebida como uma comprovação da originalidade e da atração que o NPT possui.

Neste sentido, a Universidade de São Paulo possui uma força de atração não só pela sua história acadêmica, por seus laboratórios, mas também por seu corpo docente e discente, capaz de entregar projetos de alta complexidade de forma colaborativa com empresas privadas, comprovando o papel das universidades como ambiente especializado.

Nos dizeres do Prof. Dr. Bagnato, “o Parque não é galpão e muito menos condomínio de empresas. O Parque vai além disso. Ele é o uso da capacitação tecnológica em prol do avanço, em prol da economia. (...) A universidade de São Paulo é referencia nacional e, portanto deve sim se preocupar em realizar os primeiros passos na direção de criarmos um Parque Tecnológico na cidade de São Paulo. Através da Agência USP de Inovação diversas atividades em prol da formação de um Núcleo Parque Tecnológico estão em curso. Conversas com setores públicos e privados têm possibilitado encaminhar propostas e realizar ações que deverão resultar em curto, médio e longo prazo numa mudança do panorama deste tema, inclusive com grandes impactos para a cidade e para toda a sociedade" (BAGNATO, 2017, pág. 9).

Por fim, gostaria ainda de ressaltar a abertura que a Universidade de São Paulo proporcionou ao acolher meu projeto e dar todas as condições para que este pudesse ser desenvolvido, de modo especial ao programa de Mestrado Profissional em Empreendedorismo da FEA e a Agência USP de Inovação. 


\section{BIBLIOGRAFIA}

ASSOCIAÇÃO NACIONAL DE ENTIDADES PROMOTORAS DE EMPREENDIMENTOS INOVADORES - ANPROTEC. Parques Tecnológicos no Brasil:Estudo, Análise e Proposições. 2008.

Tecnológicos. 2014 . Disponível http://www.anprotec.org.br/Relata/PNI FINAL web.pdf. Acesso: 20/03/2017.

BABBIE, E. The practice of social research. 4th ed. Belmont, Wadsworth Publ., 1986.

BAUTZER, DEISE. Inovação, Repensando as Organizações. São Paulo, Atlas 2009.

BNDES. Complexo Eletrônico: A evolução recente e os desafios para o setor e para atuação do BNDES. Disponível em: http://www.bndes.gov.br/SiteBNDES/export/sites/default/bndes_pt/Galerias/Arquivos/c onhecimento/livro60anos perspectivas setoriais/Setorial60anos_VOL1ComplexoEletro nico.pdf. Acesso: 08/10/2015

BOLY, VINCENT. Ingénierie de l'innovation. Lavoisier, Paris, 2008.

CASSIOLATO, E.; LASTRES, H. Sistemas de Inovação: Políticas e Perspectivas. Revista Parcerias Estratégicas, número 8, Maio/2000.

CARVALHO, MARLY M. Inovação: Estratégias e Comunidades de Conhecimento. Atlas, São Paulo, 2009.

CGEE - Centro de Gestão e Estudos Estratégicos. Doutores 2010: estudos da demografia da base técnico-científica brasileira. Brasília: Centro de Gestão e Estudos Estratégicos, 2010.

CHANAL, VALÉRIE. Business Models dans l'innovation. PUG, Grenoble, 2011.

CHESBROUGH, HENRY. Inovação Aberta: Como criar e lucrar com tecnologia. Bookman, Porto Alegre, 2012.

CHESBROUGH, HENRY. Modelo de negócios abertos: Como prosperar no novo cenário da inovação. Bookman, Porto Alegre, 2012.

CHRISTENSEN, CLAYTON M. O Dilema da Inovação: Quando as Novas Tecnologias levam Empresas ao Fracasso. MBOOKS, São Paulo, 2012.

DE NIGRI, J.A. e KUBOTA, L.C. Políticas de Incentivo à Inovação Tecnológica. Instituto de Pesquisa Econômica Aplicada, Brasília, 2008.

DEPINÉ, et. al. Impactos da Inovação Tecnológica no Desenvolvimento Econômico: O papel decisivo do empreendedor. Revista Filosofia do Direito e Intersubjetividade, 2011. Disponível em: www.univali.vr/direitofilosofia. Acesso: 8/10/2015. 
EDQUIST, C. Systems of Innovation: Technologies, Institutions and Organizations. London, Cassell Academic, 1997.

. The Systems of Innovation Approach and Innovation Policy: An account of the state of the art, 2001. Disponível em: http://www.tema.liu.se/tema-t/sirp/chaed.htm. Acessado em: 18/05/2017.

ETZKOWITZ, H.; LEYDESDORFF, L. The dynamics of innovation: from National systems of innovation and "Mode 2" to a Triple helix of university-industrygovernment relations. Research Policy, v. 29, p. 109-123, 2000.

FERNANDES, Edison Carlos (org.). Alterações tributária da MP do Bem: Lei 11.196/05 - MP 255. São Paulo, Quartier Latin do Brasil, 2006.

GIBBONS, M.; JOHNSTON, R. The roles of science in technology innovation. Research Policy, v.3, p. 220-242, 1974.

GIBBONS, M.; LIMOGES, C.; NOWOTNY, H.; SCHWARTZMAN, S.; SCOTT, P.; TROW, M. The new production of knowledge: the dynamics of science and research in contemporary societies. London: Sage Publications Inc., 1994.

GIL, Antonio Carlos. Como elaborar projetos de pesquisa. 4. ed. São Paulo: Atlas, 2002

HIGUCHI, Hiromi. Et al. Imposto de Renda das Empresas. 34 ${ }^{a}$ ed. São Paulo: IR Publicações, 2009.

HAMEL, Gary. Bringing Silicon Valley Inside. Harvard Business Review, 1999. Disponível em: https://hbr.org/1999/09/bringing-silicon-valley-inside. Acessado em: 20/05/2017.

JOHN BESSANT, et al. Gerenciamento da Inovação. Porto Alegre, Bookman 2010.

JOHN BESSANT, et al. Inovação e Empreendedorismo. Porto Alegre, Bookman 2010.

Le LOARNE, Et al. Management de l'innovation. Paris, Pearson, 2009.

LINHARES, F. Pintec 2014 registra estabilidade em taxa de inovação e investimento de empresas em P\&D. disponível em: http://www.agenciacti.com.br/index.php?option=com_content\&view=article\&id=10052 :pintec-2014-registra-estabilidade-em-taxa-de-inovacao-e-investimento-de-empresasem-pad\&catid=3:newsflash. Agência CTI, 12/12/2016 Acesso: 17/05/2017.

MYERS, M. Qualitative Research in Information Systems. Association for Information Systems, 1997. Disponível em: http://www.qual.auckland.ac.nz/. Acesso: 03/03/2017.

MINISTÉRIO DA CIÊNCIA, TECNOLOGIA E INOVAÇÃO - MCTI. Relatório anual da utilização dos incentivos fiscais, ano base 2012, Brasília, dezembro/2013. Site: http://www.mct.gov.br/upd_blob/0229/229781.pdf Acessado em 05/04/2015. 
http://www.mcti.gov.br/documents/10179/35540/Estrat\%C3\%A9gia+Nacional+de+Ci \%C3\%AAncia,\%20Tecnologia+e+Inova\%C3\%A7\%C3\%A3o+(Encti)\%202016-2019++ documento+para+discuss\%C3\%A3o/5a4fe994-955e-4658-a53c-bc598af09f7e Acesso: $20 / 05 / 2016$

. Relatório de Resultados da Lei de Informática - Lei 8.248/91, ano base

2014. Brasília. Disponível em: http://sigplani.mct.gov.br/arquivos/RelatorioEstatisticoA5VersaoGrafica2014v1.pdf Acesso: 20/05/2016

OECD. Taxation, Innovation and the Environment. Milton Keynes, OECD Publishing, 2010.

OECD, EUROSTAT. Manual de Oslo: Diretrizes para coleta e interpretação de dados sobre inovação. Disponível em: http://www.finep.gov.br/images/apoio-efinanciamento/manualoslo.pdf. Acessado em 14/04/2015.

OLIVEIRA, JOELMO. O Triângulo de Sábato. Sindicato dos Trabalhadores em Pesquisa, Ciência e Tecnologia. Disponível em: http://sintpq.org.br/index.php/blog/item/380-o-triangulo-de-sabato. Acesso: 30/06/2017.

OSTERWALDER, A. \& PIGNEUR, Y.; Business Model Generation; John Wiley \& sons; 2010

PARANHOS, JULIA. Interação entre Empresas e Instituições de Ciência e Tecnologia. EDUERJ, 2012.

PLONSKI, GUILHERME A. Cooperação empresa-universidade: antigos dilemas, novos desafios. Revista USP, número 25, p. 32 41, mar/maio 1995.

QS University Rankings, 2015. http://www.topuniversities.com/university-rankings/latin-americanuniversity-rankings $/ 2015 \#$ sorting $=$ rank + region $=+$ country $=+$ faculty $=+$ stars $=$ false + search $=$ Acesso em 20/05/2015.

SBRAGIA, ROBERTO et al. Inovação: como vencer esse desafio empresarial. São Paulo, Clio Editora, 2006.

SCHUMPETER,J.A. A teoria do desenvolvimento econômico. São Paulo: Nova Cultural, 1988.

SILVA, D. DEVANILDO. Articulação do Sistema de Inovação no Município de Sorocaba. Um estudo com base na experiência nacional de ambientes de inovação e nos pólos franceses de competitividade. 2009. 423p. Tese (Doutorado na Área de Tecnologia Nuclear - Aplicações) IPEN - Autarquia associada à Universidade de São Paulo, São Paulo.

THAMHAIN, HANS J. Managing Technology-based Projects. John Wiley \& Sons, 2014.

THIOLlENT, M. Metodologia da Pesquisa-Ação. Editora Cortez, São Paulo, 1986.

KELLEY, Tom. The ten faces of innovation. New York, Doubleday, 2005. 
ZOUIN, D. Parques Tecnológicos. Propondo um modelo conceitual para regiões urbanas. O Parque Tecnológico de São Paulo, 2003. 248p. Tese (Doutorado na Área de Tecnologia Nuclear - Aplicações) IPEN - Autarquia associada à Universidade de São Paulo, São Paulo. 
Anexo I - Ofício AUSPIN para Sr. Ministro MCTI

\section{AUSPIN}

OF AUSPIN n? 325-2016

Săo Paulo, 19 de outubro de 2016 .

Exmo Sr. Ministro de Estado

Dr. Gilberto Kassab

Ministro de Ciència, Tecnoloğia, Inovações e Comunicaçōes

Em consonăncia com os esforços que Vossa Excelência e sua equipe vem empreendendo no sentido do promover a maior interaçăo entre a academia e o setor privado para a ampliaçăo des investimentos em inovaç̣̂̃ no Pais. a Universidade de Săo Paulo (USP) vem, rospeitosamente, por meio deste oficio, solicitar o apoio do Ministério da Cléacla Tecnologia, Inovaçăes - Comunicaçỏes (MCTIC), no sentido do viabilizar o projeto Núcleo Parque Tecnológico (NPT@USP), inciativa pioneira no cenário acadómico brasileiro, que visa construit um relacionamento perene para o desnevolvimento de projecos de P,DQI colaborativos entre grandes empresas e a universidade.

A iniciativa será abrigada em um conjunto de prédios localizados dentro da cidade universitária, parcialmente construídos e sem utilizaçăo até a presente data. Localizado numa área de $20.000 \mathrm{~m} 2$, sendo $5.000 \mathrm{~m} 2$ de área útil total, o NPT acomodará cerca de 15 centros de inovaçấo de grandes empresas nacionais e multinacionais, 0 modelo de gestẫo inovador do projeto tem a USP/IPEN como entidades de governança e um gestor privado responsável pela intermediaçăo do relacionamento entre as companhias residentes e o ecossistema de inovação da USP.

As empresas selecionadas a participarem do empreendimento irăo fibanciar o Projeto por meio do pagamento mensal de aluguel e taxas de serviço alóm de um compromisso de investimento anual e recorrente - durante os 10 anos subsequentes- em projetos celaborativos com os grupos de pesquisa e pesquisadores da unlversidade. Trata-se portanto, de um modelo de operação auto-financiado e rentável, tão logo se conclua sua plena ocupação.

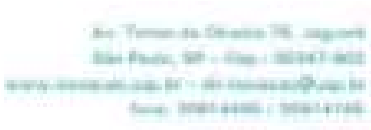




\section{AUSPIN}

Já demonstraram interesse em particpar empresas como. Natura, Accenture, SAP, Stefanini, Mahle, Rhodia, AfS Eletropaulo, Santander, Cisco, Samsune entre outras entidades de. grande porte.

Atualmente, como já é sabido por Vossa Excelència, a USP conta com recursos timitados para empreender neste campo, Apesar disso, por entender a releváncia do referido projeto, a

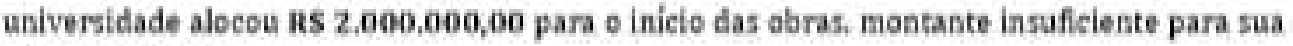
plena conclusào.

0 orçamento previsto para a implantaçio do projeto e início da operação está projetado em RS 19,512,462.23, sendo o saldo restante, após o investimento da USP citado acima, de RS 17.512,462, 23 - montante que pleiteamos nesse oficio.

Nesse contexto, o apoio do MCTIC torna-se decisivo para o lançamento da inciativa no inicio de 2017. quando gostariamos de anunciar também a parceria entre a USP e o MCTI que em nossa visăo, deve ir além do mero financiamento e avançar na integraçăo de estratécias e programas comuns, que possam impulsionar a inovaç̆o brasileira e servir de exemplo para a multiplicação de iniciativas similares.

Entendendo que se trata de um projeto referência para a realizaçăo efetiva do Parque Tecnelógico da Cidade de ST̃o Paulo, considerando que seu modelo inaggura os avanços introduzidos pelo recente Masco Regulatório da lnovaçâo (Lel 13.243/16), contamos com o pragmatismo e açẫo empreendedora que tềm marcado sua gestăo para construimos conjuntamente o que acreditamos ser um marco na elevaçẩo da inovaçảo brasileira para o mais elevado patamar internacional.
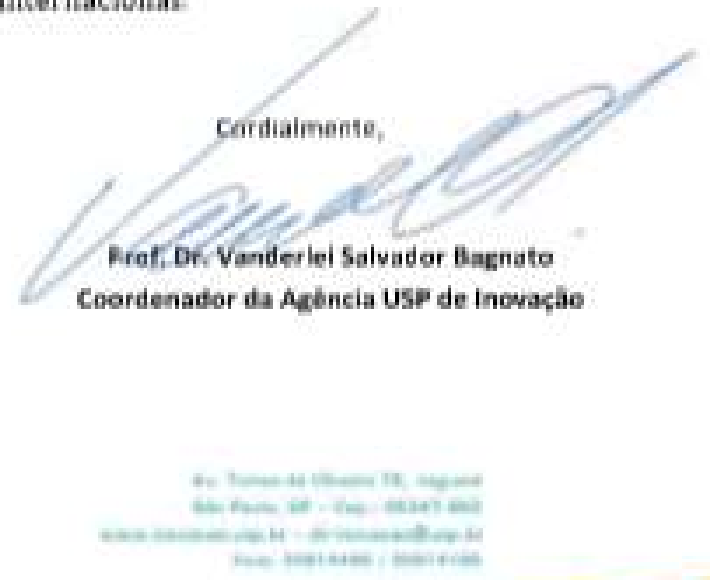


\section{Anexo II - Oficio AUSPIN ao Secretário Sr. Marcelo Strama}

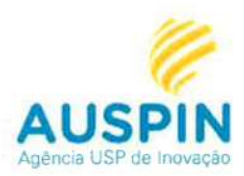

OF AUSPIN no 130-2017

São Paulo, 11 de maio de 2017

Ref: Solicitação de apoio ao desenvolvimento do projeto Núcleo do Parque Tecnológico da Universidade de São Paulo (USP)

Prezado Secretário Marcelo Strama,

De acordo com o interesse mútuo do Subsecretaria de C,T\&I e da USP/IPEN, em promover o desenvolvimento de projetos que viabilizem o melhor relacionamento entre a Universidade e empresas privadas, como foco no desenvolvimento de Parques Tecnológicos na cidade de São Paulo, vimos por meio deste solicitar o descrito abaixo:

1. A USP tomou a iniciativa de formar seu Núcleo Parque Tecnológico, com objetivo de abrigar centros de $P \& D$ de empresas consolidadas, que realizam projetos de $P, D \& I$ em cooperação com laboratórios e pesquisadores da USP e do IPEN.

2. Para continuidade dessa iniciativa a USP/IPEN está disponibilizando espaço físico - 02 edifícios de $5.000 \mathrm{~m} 2$ de área útil, em um terreno com $20.000 \mathrm{~m} 2$ - e recursos da ordem de $\mathbf{R} \mathbf{\$} \mathbf{2 . 0 0 0 . 0 0 0 , 0 0}$ que foram alocados para continuidade das obras de adequação do espaço para o projeto.

3. Para conclusão das obras e operacionalização do projeto, no entanto, há necessidade de aporte financeiro adicional. Estimamos que este apoio, pode ser concedido, resgatando convênio já firmado entre a SEDECTI, USP, IPEN e CIETEC:

O referido convênio já existente, instrumento firmado entre as partes mencionadas, foi responsável pelo aporte inicial para construção do conjunto de prédios, ora inacabados, no montante e distribuição mencionados a seguir:

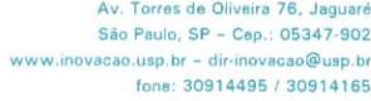




\section{AUSPIN}

\begin{tabular}{|l|l|l|}
\hline Fonte & Valor & Aplicação \\
\hline SDECTI & R\$3.580.000,00 & Obras Civis \\
\hline FINEP & R\$1.320.000,00 & Obras Civis \\
\hline MCTICI & R\$ $1.500 .000,00$ & Devolvido \\
\hline
\end{tabular}

Para adequação dos espaços e inícios das atividades do ambiente, será necessário, além do comprometimento de $\mathbf{R} \mathbf{2} \mathbf{2} \mathbf{0 0 0 0 . 0 0 0 , 0 0}$ já feito pela USP, um valor adicional de $\mathbf{R} \mathbf{\$} \mathbf{3 . 0 0 0 . 0 0 0 , 0 0}$, a ser compartilhado, segundo sugestão abaixo:

\begin{tabular}{|l|l|l|}
\hline Fonte & Valor & Aplicação \\
\hline SDECTI & R\$ 1.500.000,00 & Obras Civis/Gestão \\
\hline MCTICI/FINEP & R\$ 1.500.000,00 & Obras Civis/Gestão \\
\hline
\end{tabular}

Diante do exposto, solicitamos aos Exmo. Secretário o apoio no sentido de aportar a verba indicada na tabela acima e de intermediar as discussões junto ao MCTIC/FINEP para estimular a participação do Governo Federal no projeto com equivalente aporte.

Ressaltamos que os aportes ora solicitados, já estavam previstos na primeira fase do projeto (obras civis iniciais e gestão) e, por questões variadas, não foram integralizados.

A USP está comprometida a promover o Núcleo Parque Tecnológico, que servirá como pedra fundamental para o desenvolvimento do Parque Tecnológico da cidade de São Paulo, projeto tão desejado. 


\section{AUSPIN}

Consideramos que o apoio - financeiro e institucional - e a participação do SEDECTI nessa iniciativa é fundamental para sua viabilização e sucesso. Anexo segue versão abreviada do projeto em desenvolvimento.

Agradecemos a atenção e aguardamos sua gentileza em responder a esse ofício.

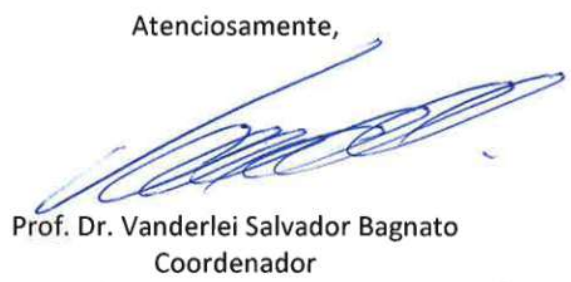

Ao Exmo. Secretário

Sr. Marcelo Strama

Subsecretaria de Ciência, Tecnologia e Inovação

$\mathrm{C} / \mathrm{C}$

Prof. Dr. Oswaldo Massambani - FINEP SP

Prof. Dr. Claudio Rodrigues - CIETEC

Prof. Dr. Wilson Calvo - IPEN

Sra. Margareth A. O. Lopes Leal - SDECTI 


\section{Anexo III - Ofício do Magnífico Reitor da USP}

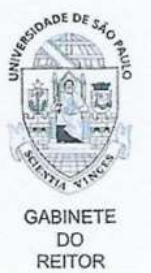

São Paulo, 5 de Junho de 2017

REF: Uso de fontes e recursos: Secretaria do Estado de são Paulo/ MCTIC/ USP

- Núcleo do Parque Tecnológico de São Paulo.

Prezados Senhores,

Complementando as discussões prévias que tivemos recentemente sobre a reativação e implantação do Núcleo Parque Tecnológico de São Paulo (NPT@USP), gostaríamos de esclarecer o uso das fontes de recursos envolvendo a USP, o Ministério de Ciências, Tecnologia, Inovação e Comunicação e a Secretaria de Ciências do Estado de São Paulo.

Conforme discutido previamente, a USP esta alocando ao Projeto o valor de $\mathrm{R} \$ 2.000 .000,00$ (dois milhões de reais), enquanto que o MCTIC e a secretaria do Estado de São Paulo, contribuirão como valor de $\mathrm{R} \$ 1.000 .000,00$ (um milhão de reais) cada um.

O uso de tais recursos permitirá concluir os blocos, hoje inacabados, convocara as empresas interessadas, dara início às atividades prevista no projeto e avançara com o programa autossustentável estabelecido. De forma abreviada, o uso dos recursos por fonte esta descrito na tabela anexa.

Informamos que embora o projeto envolva o IPEN e a USP, o IPEN não contribuirá com recursos, mas fará parte de toda governança do Núcleo.

Os recursos do MCTIC e da Secretaria do Estado de São Paulo, poderão ser concedidos através da continuidade do projeto já existente com o IPEN/CIETEC ou caso seja conveniente, através de novo convênio a ser firmado com a Universidade de São Paulo.

Agradecemos antecipadamente a atenção, e ficamos no aguardo da posição final do MCTIC e da Secretaria do Estado de São Paulo.

Atenciosamente,

Ao Exmo. Sr. Marcelo Strama

Subsecretaria de Ciência, Tecnologia e Inovação

Ao Exmo. Diretor da FINEP - Regional São Paulo

Pof. Dr. Oswaldo Massambani , Finep-SP

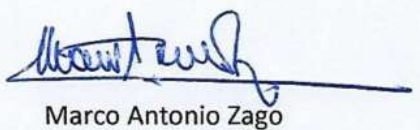

Marco Antonio Zago Reitor da Universidade de São Paulo 


\section{Tabela}

Resumo do uso dos recursos, por fonte, para instalação do Núcleo do Parque Tecnológico de São Paulo

\begin{tabular}{|l|l|l|}
\hline ORIGEM DOSRECURSOS & VALOR( R\$̦) & USO PRETENDIDO \\
\hline USP & 2.000 .000 & $\begin{array}{l}\text { Conclusão da pavimentação, portaria e } \\
\text { estacionamento dos atuais blocos } \\
\text { Adaptação do espaço para abrigar as empresas } \\
\text { especificas } \\
\text { Estabelecimento da equipe de gestão, } \\
\text { governança e formulação da programação do } \\
\text { núcleo }\end{array}$ \\
\hline $\begin{array}{l}\text { SECRETARIA DE C\&T - SÃO } \\
\text { PAULO }\end{array}$ & 1.000 .000 & $\begin{array}{l}\text { Estabelecimento da estrutura elétrica. } \\
\text { Estabelecimento da estrutura hidráulica } \\
\text { Pintura e acabamento interno } \\
\text { Parcial apoio ao inicio da gestão do Núcleo }\end{array}$ \\
\hline MCTIC & 1.000 .000 & $\begin{array}{l}\text { Adequação de espaço para gestão e goernaça } \\
\text { Sistema de segurança } \\
\text { Infraestrutura de informática } \\
\text { Realização da chamada publica para as empresas } \\
\text { Parcial apoio ao início da gestão e governança }\end{array}$ \\
\hline
\end{tabular}




\section{Anexo IV - Carta de Intenção da Caixa Econômica Federal}

\section{CAIXA \\ Ftotes:}

\section{Carta de Intençāo}

Núcleo Parque Tecnológico da Universidade de Săo Paulo

Såo Paulo, 15 de Maio de 2017.

Prezado Prof. Dr Vanderlei Bagnato.

A CAIXA ECONOMICA FEDERAL, inscrita no CNPJ/MF sob $n^{\circ}, 00.360 .305 / 0001-04$, com sede na Cidade de Brasilia. Distrito Federal, no Setor Bancario Sul, Quadra 4, CEP 70092-900, vem por meio desta formalizar seu interesse em participar do projeto Núcleo Parque Tecnologico da Universidade de Såo Paulo (NPT@USP) como Residente-Cotista Ancora e solicita a reserva prévia da referida cota. assim como o envio da minuta contratual do projeto, assim que esta seja disponibilizada pela Agéncia USP de Inovaçâo.

Atenciosamente.

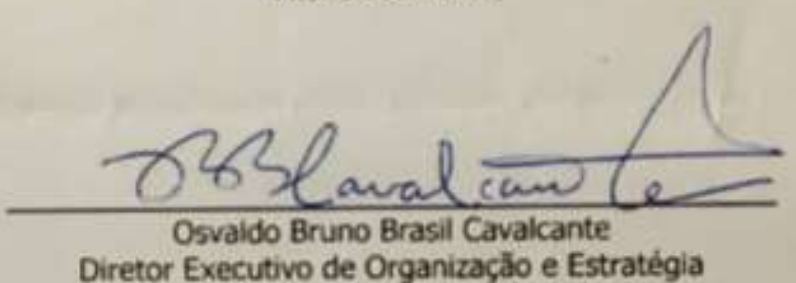

Diretor Executivo de Organizaçāo e Estratégia

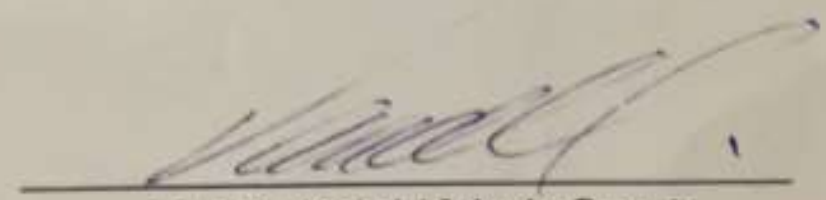

Prof. Dr. Vanderlei Salvador Bagnato

Diretor da Agência USP de Inovaçâo 
Anexo V - Proposta de Constituição e Desenvolvimento do NPT

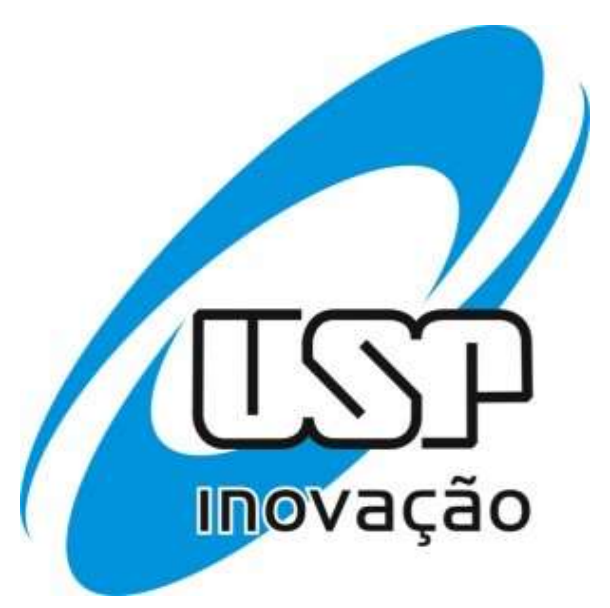

Proposta de Constituição e Desenvolvimento

Núcleo Parque Tecnológico da USP

USP

2016 
Sumário

1. Cenário

4

2. Justificativa

5

3. Proposta

7

4. Eixos de Atuação

9

5. Modelo de Governança

14

6. Modelo de Adesão

15

7. Demandas

19 


\section{Cenário}

O ambiente de inovação brasileiro passou por grandes mudanças no final de 2004, quando foi sancionada a Lei 10.973, amplamente difundida como Lei de Inovação federal, e com sua regulamentação em 2005. Esse novo marco legal permite que as instituições públicas participem do processo de inovação, regulando a transferência de tecnologia e a interação entre instituições científicas e tecnológicas (ICTs) e empresas, e orientando sobre os incentivos à inovação e à pesquisa científica e tecnológica no ambiente produtivo. Na sequência, em novembro de 2005, foi sancionada a Lei 11.196, também conhecida como Lei do Bem, que prevê incentivos fiscais para empresas que realizem atividades de pesquisa, desenvolvimento e inovação tecnológica. Essas iniciativas foram alavancadas por uma forte ampliação dos programas nacionais de fomento à inovação, com aumento das chamadas para projetos de inovação tecnológica em parceria ICTs-Empresas.

O protagonismo dos ICTs como os ambientes preferenciais para o desenvolvimento de projetos inovadores que envolvam universidades e empresas foi ainda ampliado em 2015 com aprovação do Código Nacional de Ciência e Tecnologia pela Câmara dos Deputados. A nova Lei avança na flexibilização dos contratos entre ICTs e pesquisadores com dedicação exclusiva- permitindo a remuneração direta pelo projeto executado.

As regras citadas, acrescidas de mecanismos adicionais de incentivo à inovação implementados ao longo do último ano, permitiram o florescimento do mercado de ICTs, com a constituição de 173 organizações desse tipo, e o ingresso efetivo do setor privado no ambiente acadêmico para a produção e comercialização de conhecimentos desenvolvidos no âmbito das universidades públicas. 


\section{Justificativa}

A performance da inovação tecnológica dentro de uma sociedade baseada em conhecimento, como a que vivemos atualmente, pressupõe a existência de um complexo sistema de interação entre seus diversos atores, Governo-UniversidadeEmpresa.

Do ponto de vista da geração de conhecimento, a Universidade de São Paulo possui um papel de protagonista, seja pelo conjunto de seu corpo docente nas mais diversas especialidades, seja pela qualidade de seus laboratórios de pesquisa.

Figura 2 - Ecossistema USP

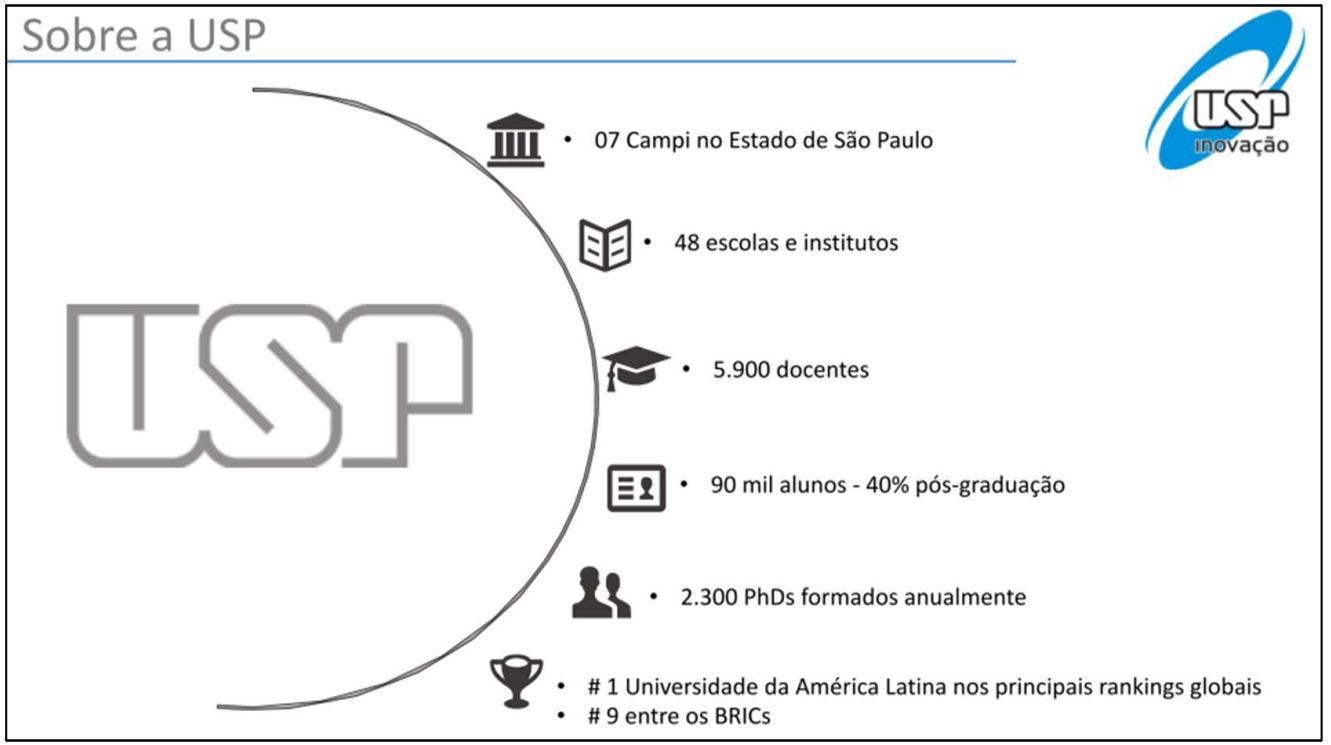

Em recente estudo do Instituto de Pesquisa Econômica Aplicada (IPEA) ${ }^{1}$, salienta-se que a questão fundamental no sistema de inovação é a articulação entre desenvolvimento tecnológico e produção científica:

\footnotetext{
${ }^{1}$ IPEA, TD 1901 - Relações Universidade-Empresa no Brasil: O Papel da Infraestrutura Pública de Pesquisa (2013)
} 
"Esta articulação e interação entre produção científica e desenvolvimento tecnológico, entre oferta e demanda de conhecimento, entre a pesquisa básica e aplicada e o desenvolvimento de novos produtos e processos seria, portanto, a chave de um sistema de inovação capaz de alavancar o desenvolvimento econômico dos países.” (pág. 11).

Esta "chave" verifica-se na prática. Ainda de acordo com o IPEA ${ }^{2}$, num estudo realizado com 1.199 empresas brasileiras, apenas $1,7 \%$ do total das empresas tinham inovação e diferenciavam seus produtos. Porém, elas eram responsáveis por mais de $25 \%$ do faturamento total das empresas e empregavam $13,3 \%$ do total de recursos humanos. (pág. 19).

Entretanto, para otimizar a interação entre a Universidade e as Empresas faz-se mister a criação de um Pólo Tecnológico capaz de abrigar centros de inovação colaborativa de empresas de grande e médio porte dentro do ambiente da USP, cumprindo com sua missão neste tema:

"A política de inovação tecnológica da USP é gerida pela Agência USP de Inovação, de modo a promover a utilização, pela sociedade, do conhecimento científico, tecnológico e cultural produzido na Universidade."3

Do ponto de vista econômico, a Universidade de São Paulo vem diminuindo sua capacidade de atrair investimentos. Por exemplo, no último Relatório de Resultados da Lei de Informática disponibilizado pelo Ministério da Ciência, Tecnologia e Inovação (MCTI), ano base 2014, podemos constatar que a participação da USP na recepção de investimentos privados de caráter tem sido marginal quando comparados com outras entidades. De um total de R $\$ 227$ Milhões investidos, apenas R\$ 1,89Milhões foram capturados pela $\mathrm{USP}^{4}$ (pág. 34).

A falta de um ambiente colaborativo onde empresas de médio e grande porte possam estabelecer centros de inovação tecnológica próprios dentro do campus universitário e assim serem capazes de interagir com o ambiente acadêmico favorece este cenário.

\footnotetext{
2 IPEA, Políticas de Incentivo à Inovação Tecnológica - Brasília, 2008.

${ }^{3} \mathrm{http}: / /$ www5.usp.br/pesquisa/inovacao-tecnologica/

${ }^{4} \mathrm{http}: / /$ sigplani.mct.gov.br/arquivos/RelatorioEstatisticoA5VersaoGrafica2014v1.pdf
} 
Por outro lado, para a melhor performance destes projetos colaborativos e consequente atração de investimento privado, a universidade precisa vencer alguns desafios impostos pelo mercado corporativo. Os compromissos com prazos e expectativas dos entregáveis devem estar alinhados com os padrões de mercado. Neste sentido, o ambiente burocratizado de uma universidade pública implica em um obstáculo muitas vezes intransponível para as empresas privadas.

Neste sentido, as possibilidades abertas pelo novo marco legal da inovação (13.243/16) vem em auxílio para superação destas barreiras, propiciando a construção de ambientes privados dentro do ecossistema público da universidade, focados no desenvolvimento da inovação tecnológica com a finalidade de melhorar a interação universidade-empresa dentro de uma visão sistêmica do processo de inovação (Governo-Universidade-Empresa).

\section{Proposta}

Constituir e desenvolver o Núcleo do Parque Tecnológico (NPT) da USP, um ICT Privado ligado à Universidade de São Paulo(USP), com gestão profissionalizada e governança definida e gerenciada pala USP, de forma a garantir maior flexibilidade na gestão e no relacionamento com as empresas parceiras, resguardando independência do ICT e a manutenção dos objetivos dos seus mantenedores.

A opção pela constituição de um ICT privado, contando com a USP como fundadora e quotista minoritária, se mostra como a mais viável, dada a flexibilidade oferecida por esse tipo de instituição e sua função desburocratizante, fundamental para a construção de um ambiente favorável ao recebimento de recursos financeiros de empresas.

$\mathrm{Na}$ tabela abaixo é possível verificar as diferenças fundamentais entre ICTs privados e públicos. 


\subsection{Diferenças entre ICTs públicos e privados:}

A fundação de um ICT privado, ainda que ligado e submetido diretamente à USP, também se justifica pela experiência recente, que têm demonstrado uma taxa elevada de sucesso dos ICTs privados ligado às instituições de renome. Entre as experiências mais bemsucedidas, é possível citar o caso do C.E.S.A.R, instituição recifense fundada no âmbito do Centro de Informática da Universidade Federal de Pernambuco (UFPE); CPqD, fundação convertida em ICT privado, ligada à Universidade de Campinas (UNICAMP); e o Instituto Eldorado, ICT fundado pela Motorola, hoje gerenciado por pesquisadores oriundos da UNICAMP.

\section{ICT PÚBLICO}

\section{ICT PRIVADO}

\section{Classificação Jurídica}

Órgão Público
Entidade privada sem fins lucrativos

Regime Legal

Direito Administrativo

Enquadramento Legal
- Possui legislação específica para relacionamento com entes privados;

- Lei de Inovação (10.973/2004) e Decreto de Regulamentação (5.563/2005);
- Não necessita seguir a Lei de Inovação, mas pode se aproveitar dos seus parâmetros e benefícios;

- Relação comercial entre as partes;

- Pode ter cláusulas bem restritivas de sigilo, prazos, multas;

- PI acordada entre as partes: uni ou bi lateral;

\section{Compromissos}




\subsection{ICTs privados e seu desempenho recente:}

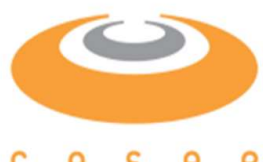

C. E. S . A , R

- ICT Privado, constituído por professores da UFPE

- Foco em TIC

- Faturamento em 2014: $\mathrm{R} \$ 90$ milhões

- Cerca de 1.000 colaboradores (mais de $100 \mathrm{PhDs}$ )

- Cerca de 50 clientes ativos

- 30 startups criadas

- Mantenedores: Motorola, Procenge, FirCapital, Grupo JCPM
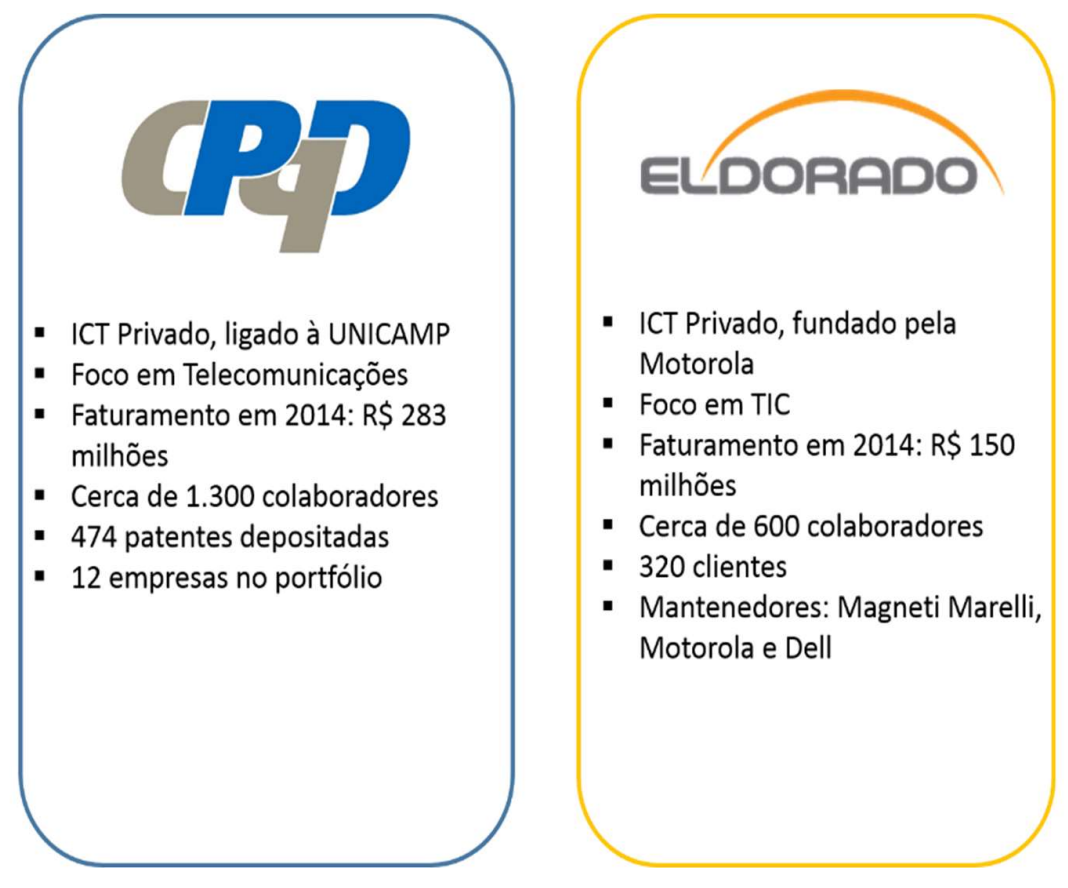

\section{Eixos de Atuação}

Como no caso da grande maioria dos ICTs privados, e considerando a capacidade de geração de conhecimento do ecossistema USP, o modelo de atuação do NPT-USP deve estar alinhado às melhores práticas de mercado e permitir que as empresas acessem o máximo de competências disponíveis no vários departamentos da Universidade, aos mesmo tempo em que possam se aproveitar dos benefícios fiscais integrantes do Sistema Nacional de Inovação, para ofertar o funding necessário à execução de tais atividades. 
Desta forma, incialmente, propomos a estruturação de 05 linhas de atuação macro:

- Pesquisa básica: Estruturação e execução de projetos de pesquisas em colaboração com empresas, instituições parceiras. Neste caso, poderemos ofertar pesquisas em andamento no ambiente da USP ou estruturar novos projetos de acordo com a demanda dos parceiros NPT.

- Pesquisa aplicada: Desenvolvimento de produtos e serviços para/em conjunto com empresas e instituições parceiras, com propriedade intelectual negociada a partir das regras do mercado de ICTs. Aqui também poderemos ofertar desenvolvimentos em andamento no ambiente da USP ou estruturar novos projetos de acordo com a demanda dos parceiros NPT.

- Programas educacionais: Desenvolvimento, gestão e execução de programas educacionais próprios do NPT ou financiamento de programas USP de interesse dos parceiros do ICT.

- Innovation Condo: Conceito inovador no Brasil, inspirado no modelo dos Science Parks do Reino Unido (http://www.ukspa.org.uk/) - ambientes onde empresas de grande porte, em sua maioria multinacionais, gerenciam laboratórios dedicados para o desenvolvimento de projetos colaborativos em conjunto com centros de referência em P,D\&I do País. Nesse sentido, será possível utilizar as instalações do edifício IPEN/AUSPIN (ver foto abaixo) para hospedar laboratórios de empresas, gerando receita imediata para o NPT e sua mantenedora principal, a USP.

- Incubadora de Startups: Considerando o potencial de geração de conhecimento do NPT, e sua finalidade não lucrativa, é natural desenvolver um ambiente para fomento de novos negócios, financiado pelo excedente de caixa do projeto, de forma a fortalecer a vocação de mercado do projeto 


\subsection{Edifício sede do projeto:}

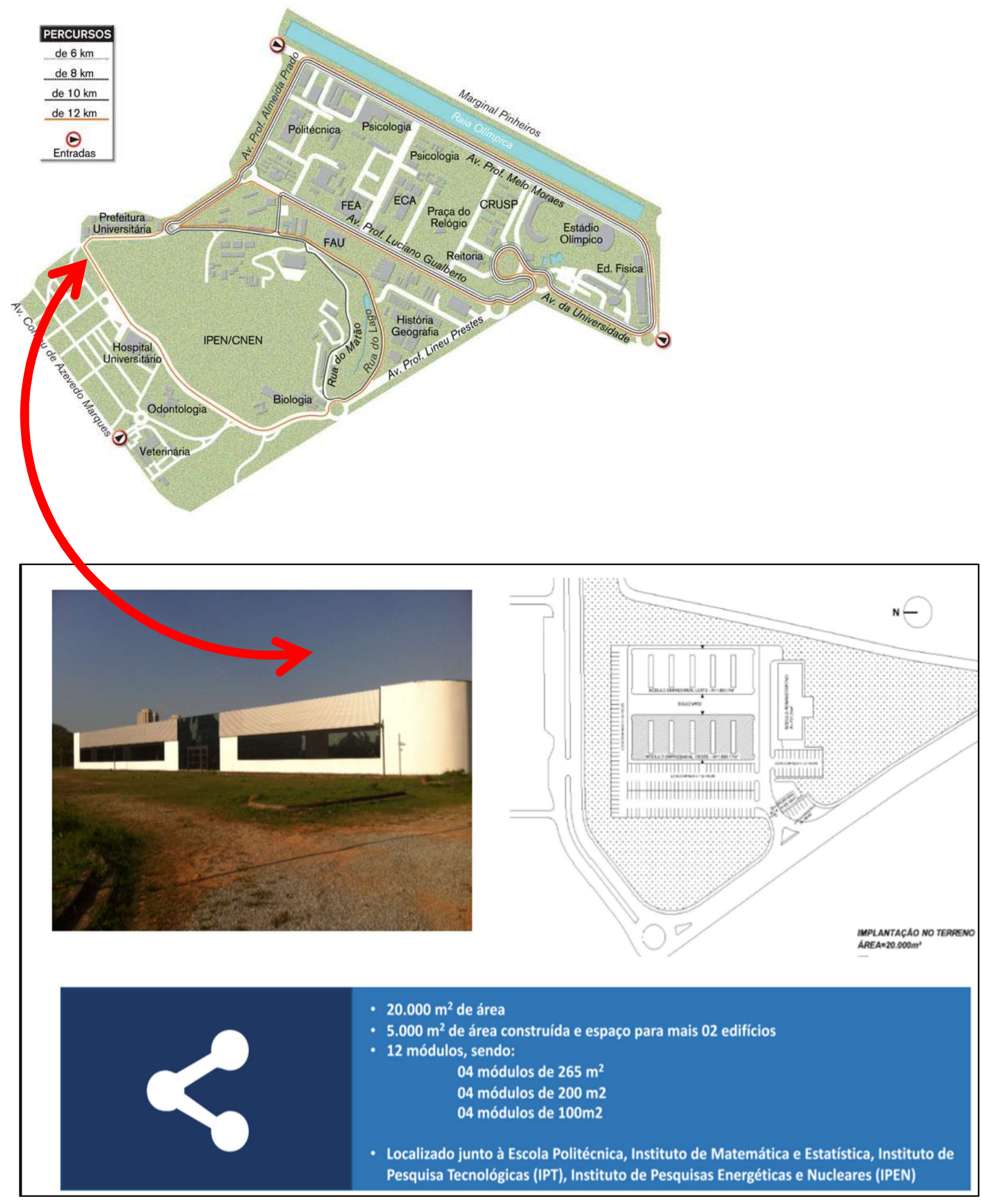




\subsection{Ecossistema NPT:}

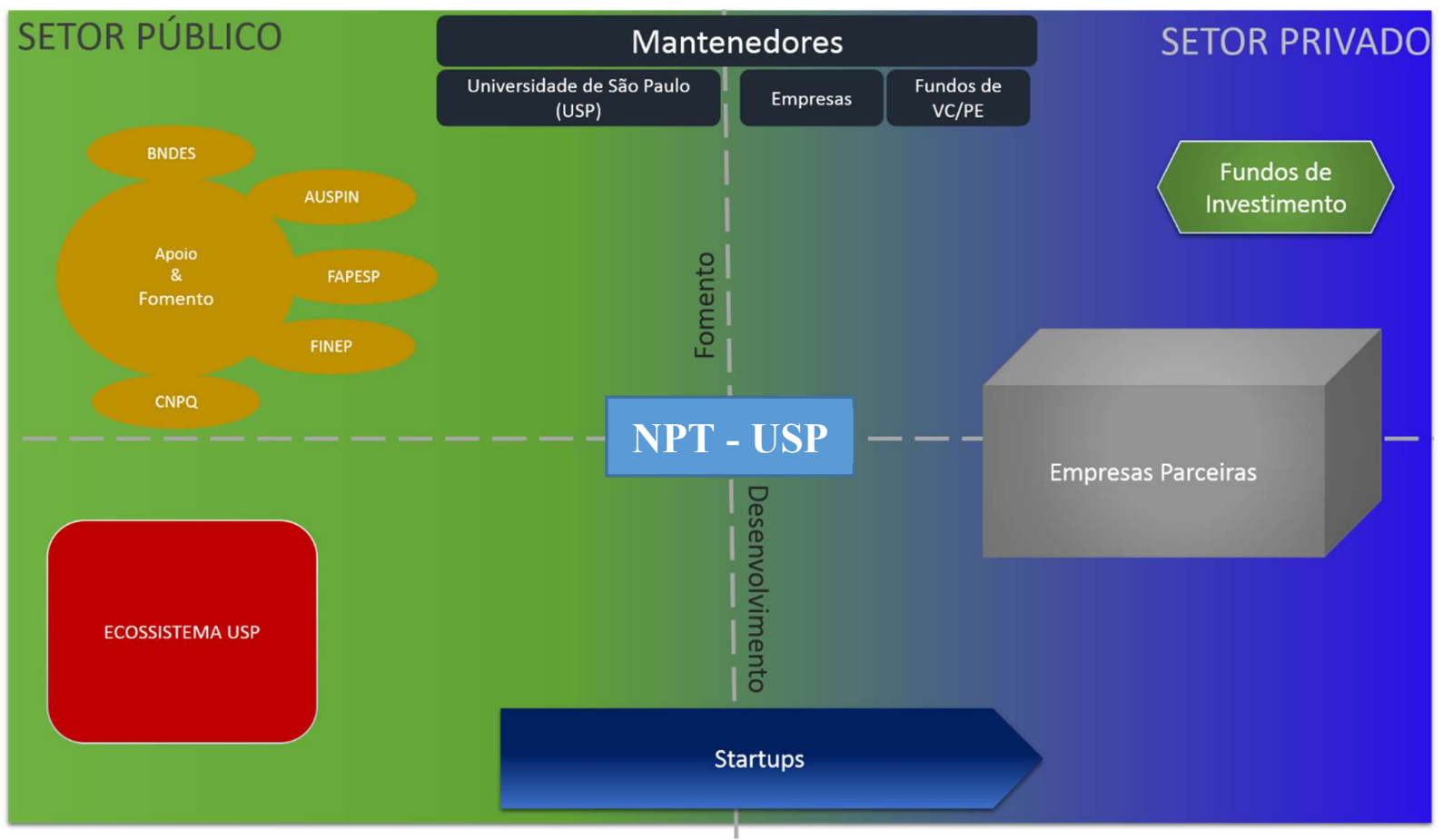

Para conferir eficiência e eficácia ao projeto, o NPT vai contar com uma gestão profissionalizada, modelada de acordo com as melhores práticas de mercado, contando com uma estrutura funcional semelhante ao das empresas com as quais se relacionará.

O time de gestão, no entanto, terá suas atividades subordinadas às estratégias definidas pelas políticas de governança a serem estabelecidas pela USP e demais instituições integrantes do Conselho de Administração (ver capítulo 5).

Do ponto de vista de captação de recursos, o NPT contará com um escritório de negócios externo, remunerado exclusivamente com base em seu desempenho - formato desenhado para estimular a abertura constante de novas frentes de negócios. O mesmo modelo será adotado para o gerenciamento das atividades legais - também realizadas por escritório externo - de forma a conferir celeridade à celebração e gestão de contratos celebrados entre o ICT e empresas/instituições parceiras.

Cabe ressaltar que questões relacionadas ao gerenciamento de propriedade intelectual, comercialização de produtos gerados no NPT e demais questões relacionadas ao 
conhecimento gerado no projeto serão submetidos à gestão do seu Núcleo de Inovação Tecnológica (NIT), neste caso, a Agencia de Inovação da USP (AUSPIN).

O NPT ainda contará com um Conselho Científico, constituído com o propósito de recomendar e analisar projetos a serem desenvolvidos. O Conselho deverá ser formado por pesquisadores da USP com desempenho excepcional em suas linhas de atuação.

\subsection{Organograma funcional sugerido:}

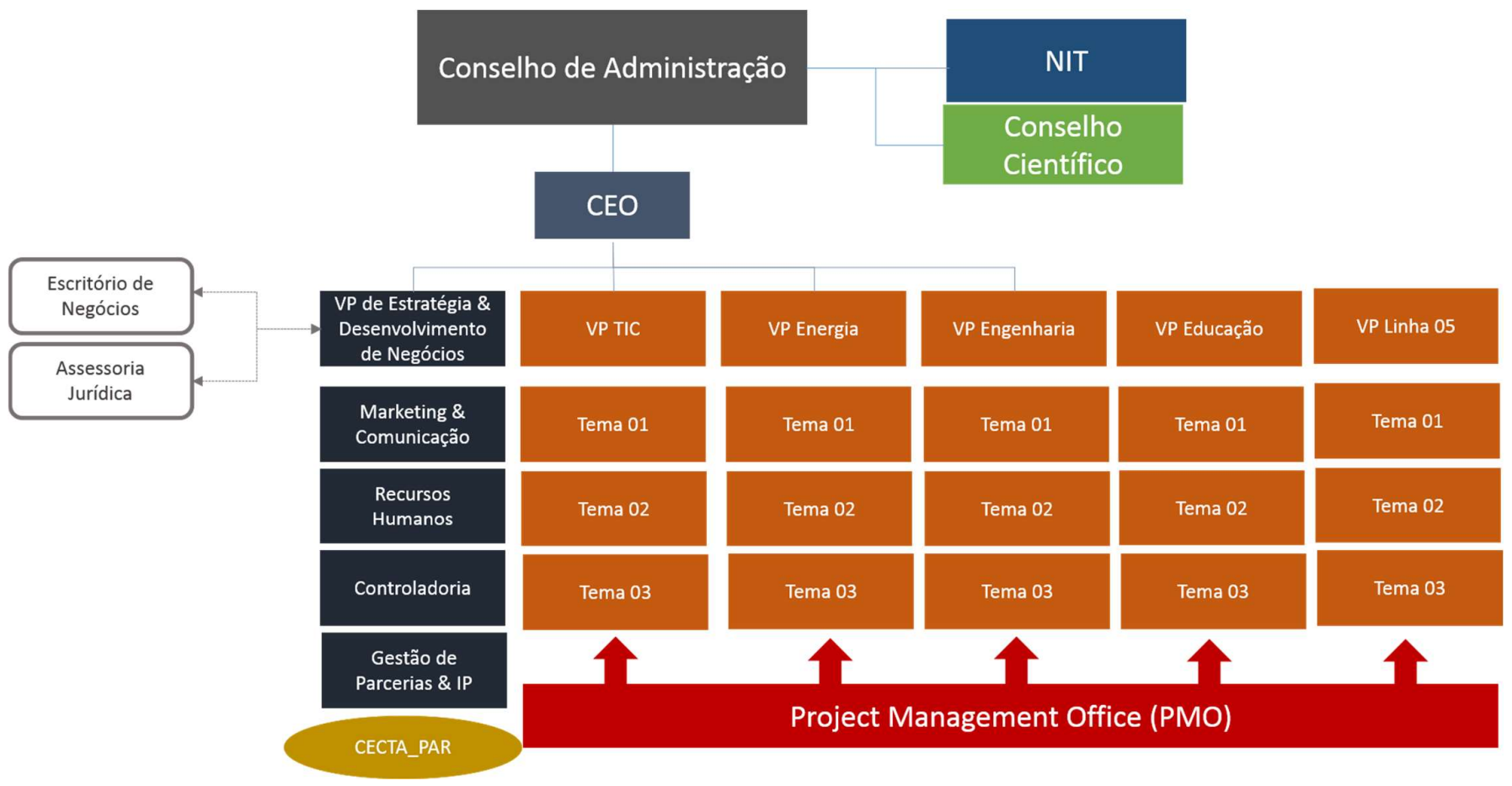




\section{Modelo de Governança}

A governança do NPT será definida e gerenciada pela USP, tendo como principal ator a AUSPIN. Sua estrutura está distribuída em 03 camadas, a saber:

- Camada Estratégica: Define os objetivos do projeto, supervisiona as atividades do time executivo e emite as orientações estratégicas do NPT.

- Camada Operacional: Traduz as orientações estratégicas da Camada Estratégica em um programa executável.

- Camada Tática: Implementa as ações necessárias para a realização dos planos estratégico e tático do NPT.

\subsection{Estrutura de Governança:}

As instâncias de Governança

Estratégica são responsáveis por

definir os objetivos do ICT e estruturar

as condições para que estes sejam

atingidos.

Caracterizado por: Orientar e Decidir

A camada de Governança Operacional deve traduzir os objetivos do ICT em um programa executável.

Carcterizado por: Recomendar e Implementar

A camada de Governança Tática executa as estratégias definidas e o programa de P\&D do ICT.

Caracterizado por: Executar e Crescer

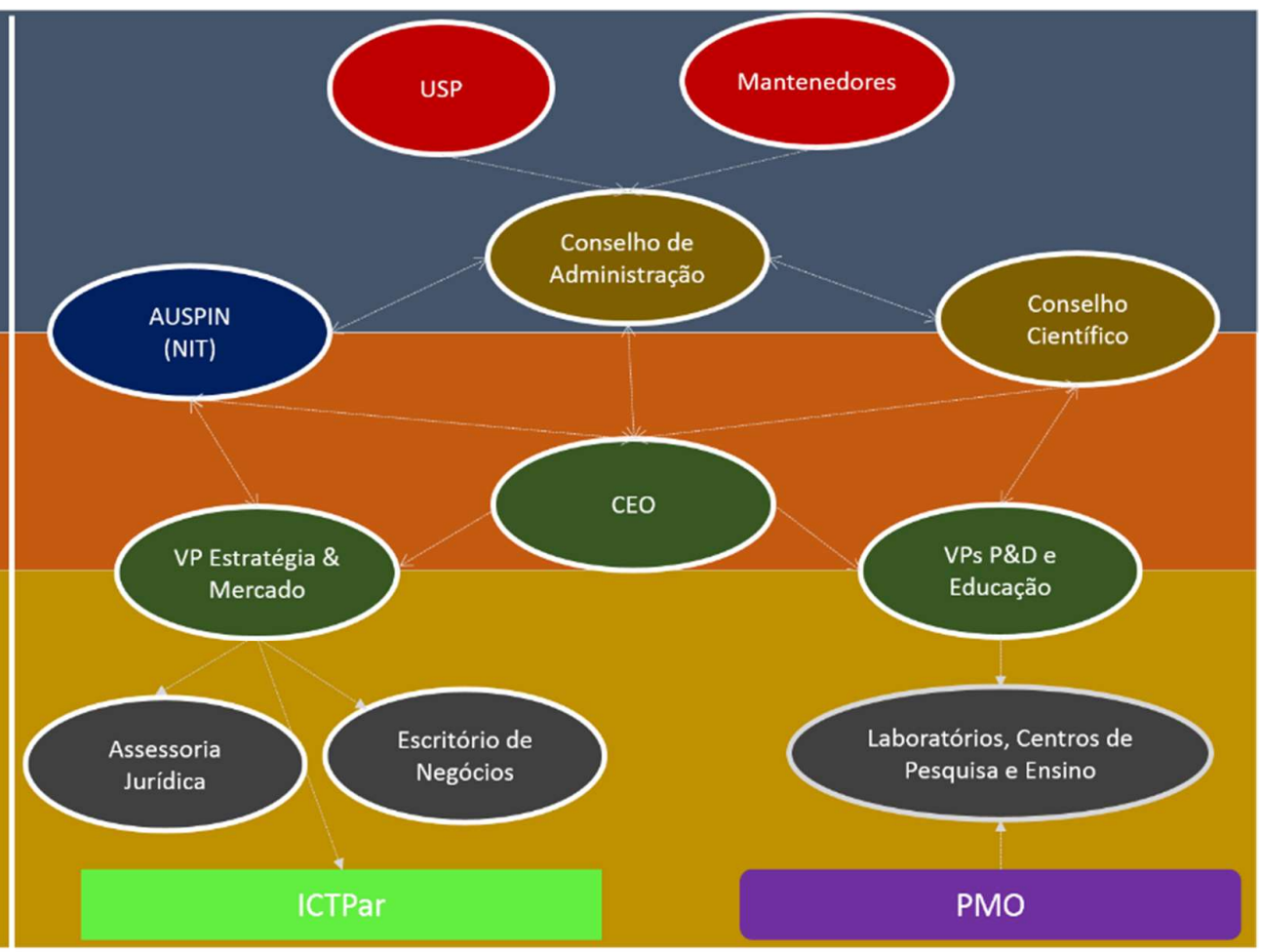




\section{Modelos de Adesão}

O NPT é composto por 12 módulos:

- 04 Cotas tipo Âncora com módulos de 265m2 ;

- 04 Cotas tipo Master com módulos de 200m2;

- 04 Cotas tipo Sênior com módulos de 100m2 .

O NPT fornecerá um pacote de serviços básicos incluídos na taxa de serviços. Um cardápio de serviços especializados abatível do comprometimento de investimento anual também será ofertado, como a tabela a seguir:
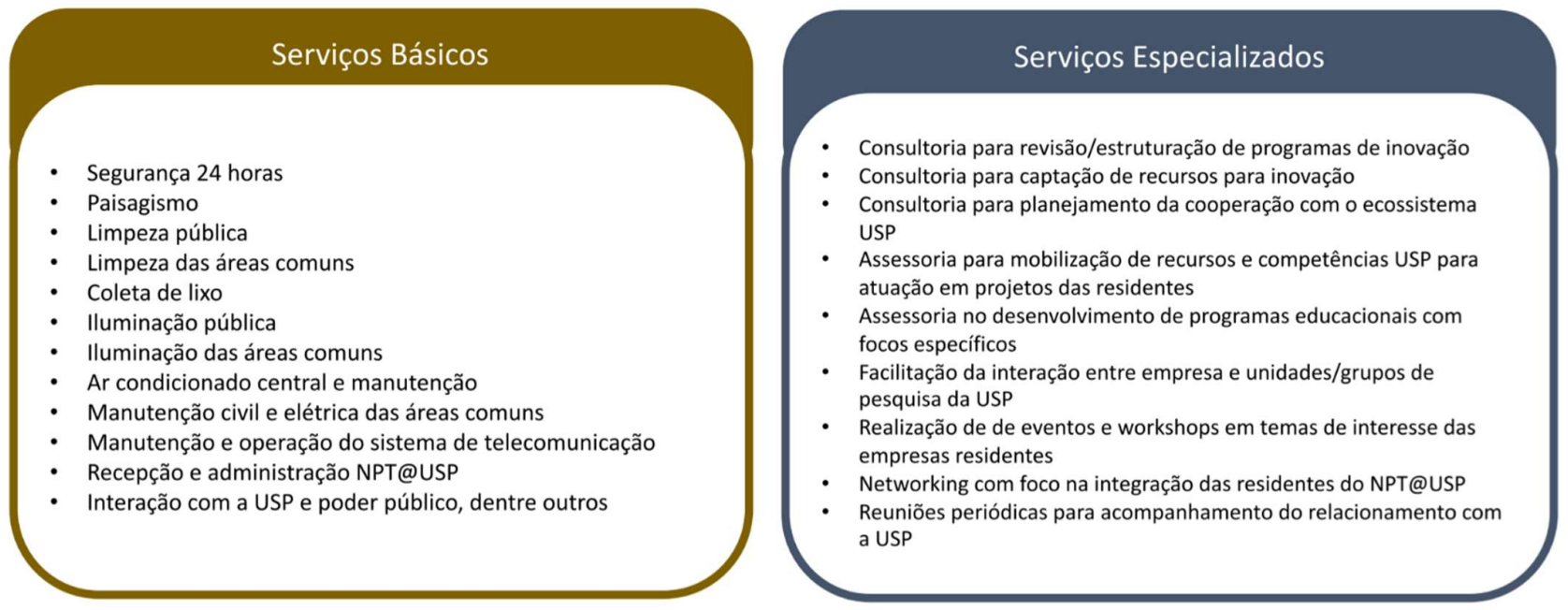


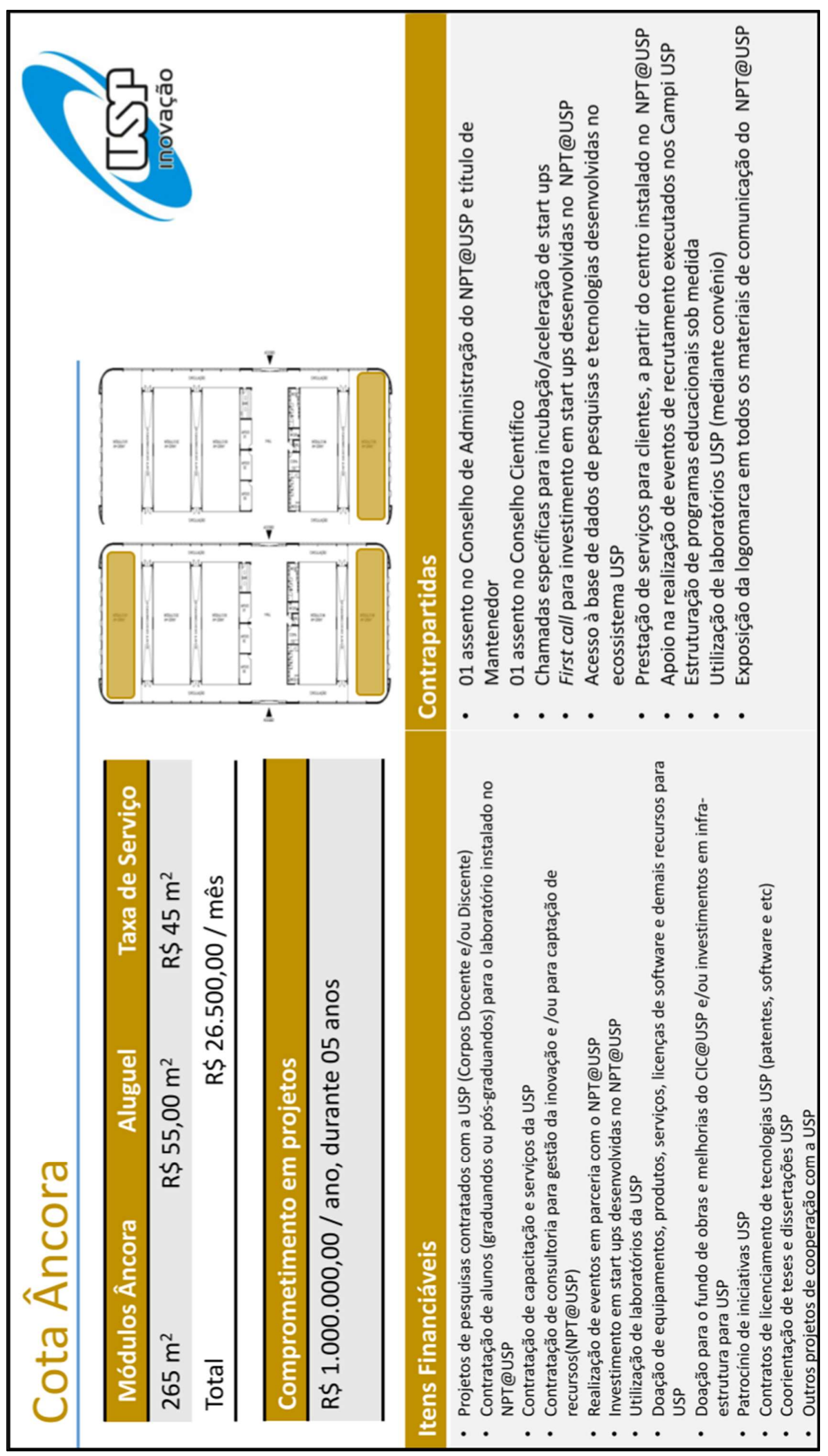




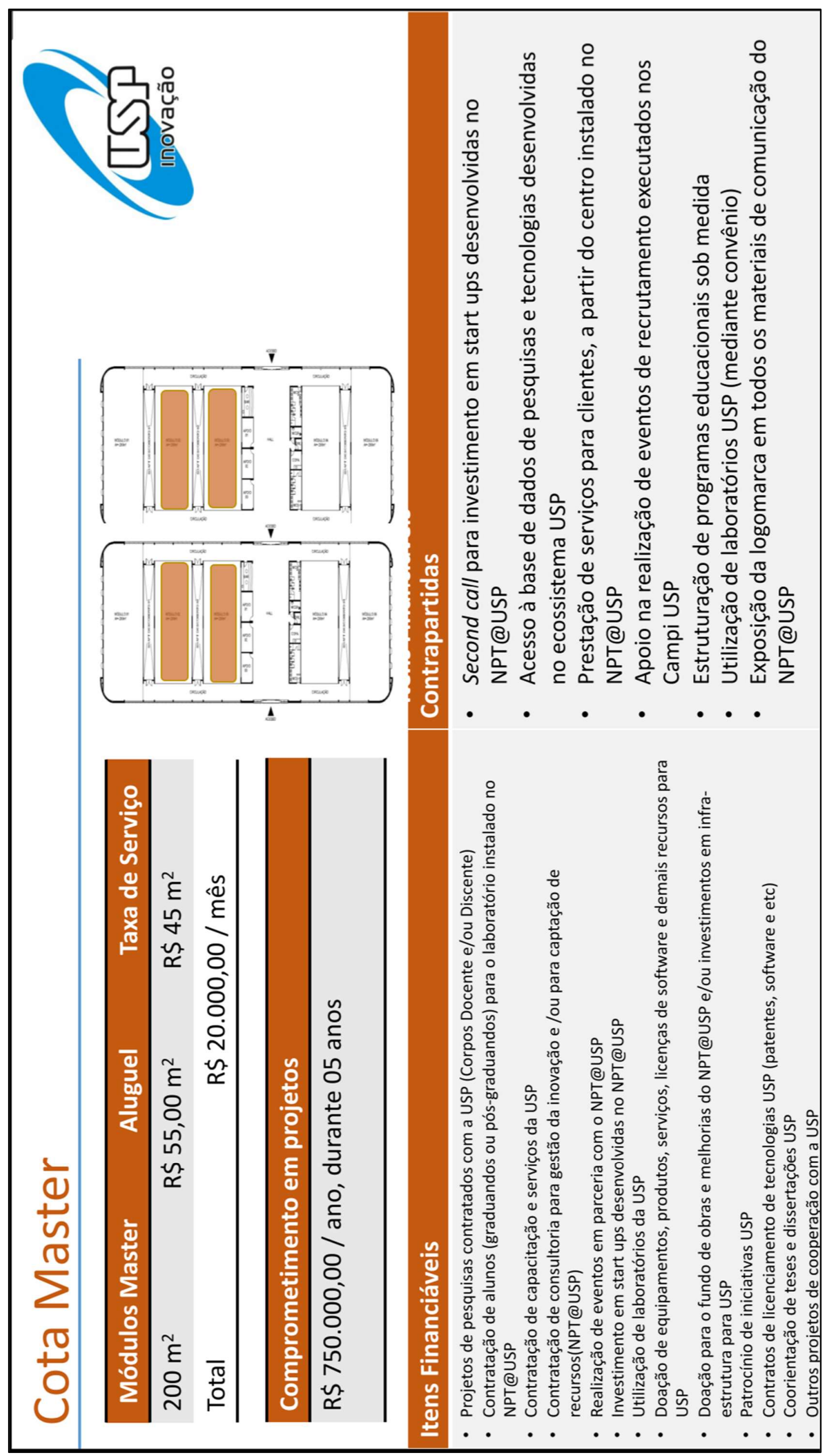




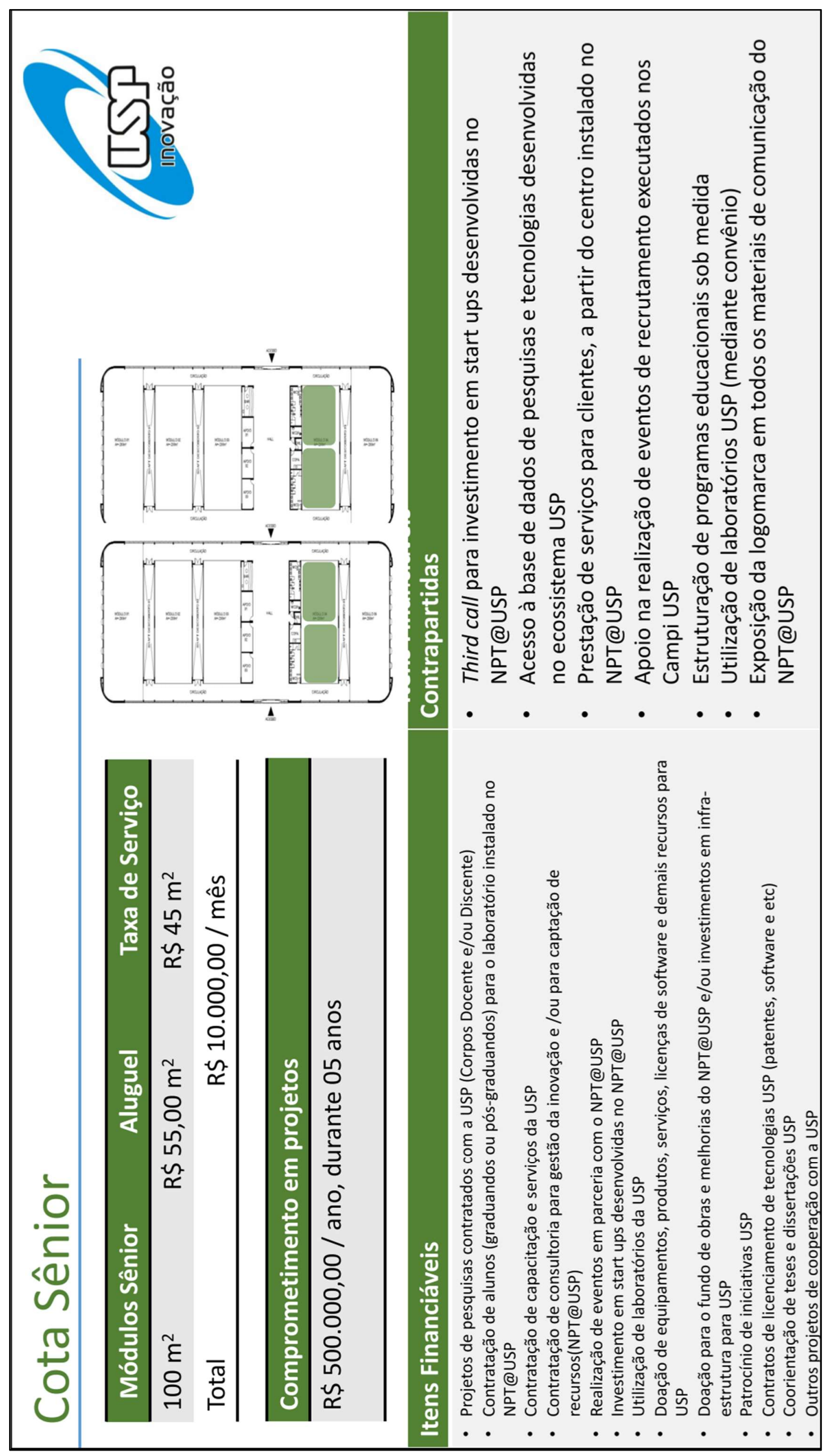




\section{Demandas}

\subsection{Implantação do Projeto}

\section{Área Externa}

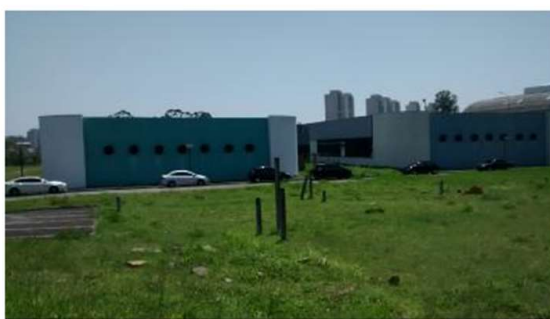

ARRASAMENTO DAS ESTACAS EXISTENTES

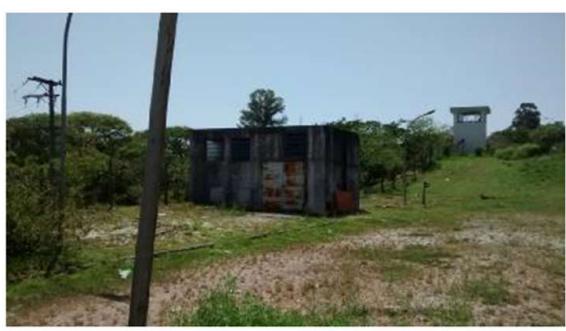

CABINE PRIMÁRIA A REFORMAR

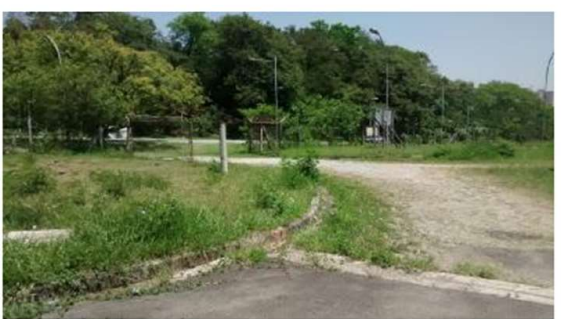

DEMOLIÇÃO ALAMBRADO E LIMPEZA DO TERRENO

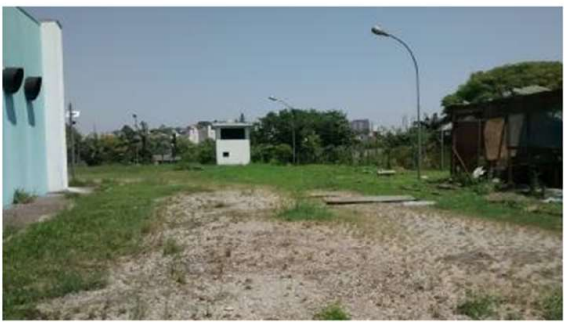

GUARITA DO EXTACIONAMENTO A REFORMAR

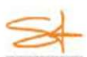

AROUTETOS
ASSOCLADOS

\section{Área Externa}

ITENS CONSIDERADOS NO ORÇAMENTO

Demolição: alambrado, mourões, arrasamento de estacas Limpeza do terreno

Construção: Canteiro de Obras, Fechamento metálico em torno do terreno, Reservatório de água, Cabine primária Portaria e calçada externa

Plantio: Grama

Instalação: lluminação (postes

Pintura: cabine primária e guarita do estacionamento

Pavimentação: novo asfalto em toda área de circulação de veículos

Projetos: Arquitetura, Estrutura metálica, Estrutura, Instalações elétricas e hidráulicas, Luminotécnica, Paisagismo e

Pavimentação

Prazo da Obra: 90 dias

CABINE PRIMÁRIA

Valor: R\$ $4.971 .519,40$

Obs: Valor mínimo de investimento para poder iniciar a obra do módulo

Leste ou Oeste: RS 1.800.000,00

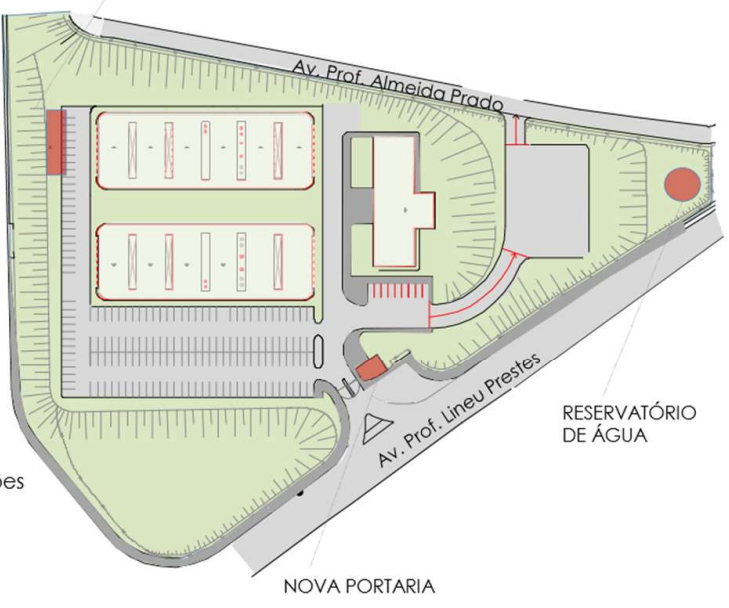




\section{Módulo Oeste}

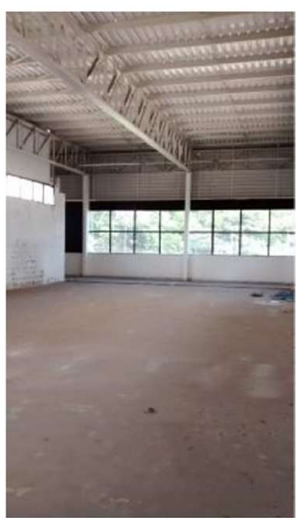

COBERTURA SERÁ FINALIZADA

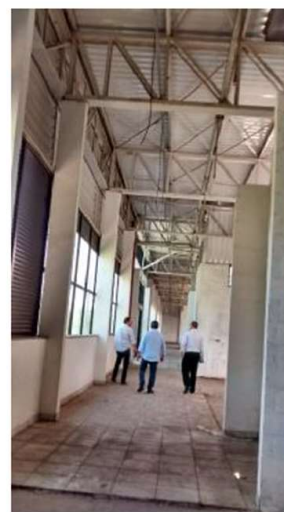

PISO DEMOLIDO E SUBSTITUIDO

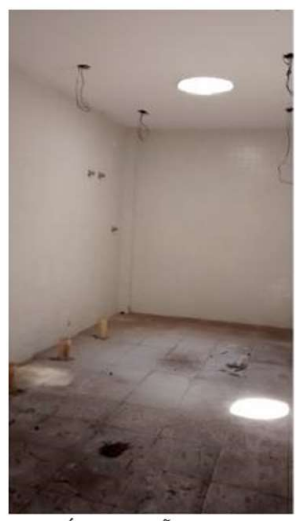

SANITÁRIOS SERÃO CONSTRUIDOS

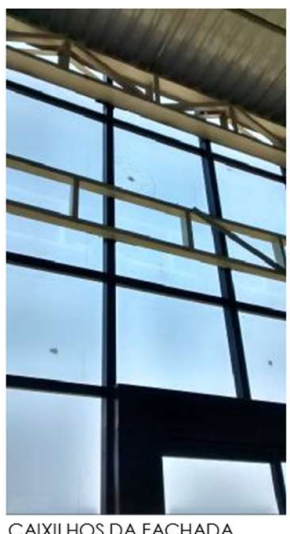

SERÃO REV

\section{$\sum 4$

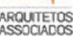

\section{Módulo Oeste}

ITENS CONSIDERADOS NO ORÇAMENTO

Demolição: Todo piso interno

Construção: sanitários, copa, calçada externa,

forro de gesso, regularização de todas as paredes internas. Revisão dos caixilhos da fachada

Cobertura: Colocaçâo de rufo e membrana

Instalação: Ar condicionado

Pintura: Toda edificação externamente e internamente, Proteção contra incêndio

Projetos: Arquitetura, Instalações elétricas e hidráulicas, Luminotécnica, Ar condicionado e Proteção e Combate a incêndio

Prazo da Obra: 60 dias

Valor: $\mathbf{R} \$ \mathbf{2 . 7 5 5 . 8 3 0 , 3 4}$

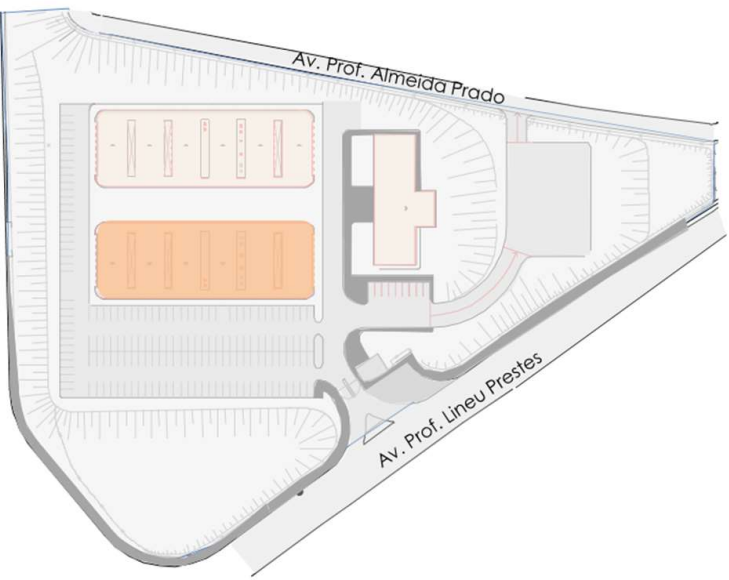




\section{Módulo Leste}

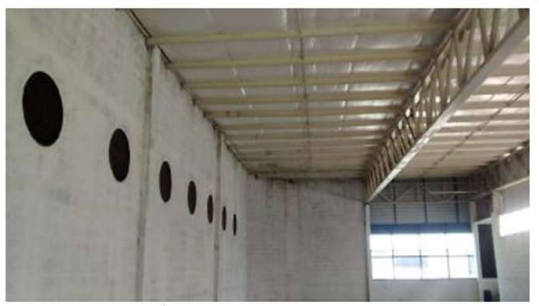

COBERTURA SERÁ REVISADA
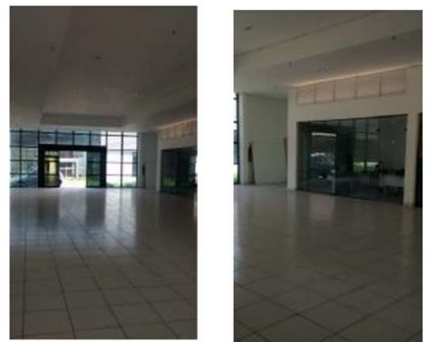

FORRO DE GESSO DEMOLIDO E SUBSTITUIDO

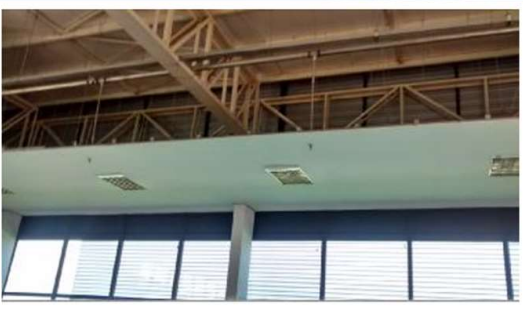

PISO CIRCULAÇÃO, DIVISÓRIAS DE VIDRO, COPA E SANITÁRIOS SERÃO DEMOLIDOS E REFORMADOS

\section{$\sum 1$}

ARQUITETOS
ASSOCACOS

\section{Módulo Leste}

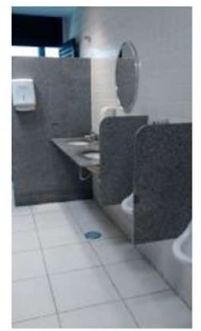

\section{ITENS CONSIDERADOS NO ORÇAMENTO}

Demolição: todo piso interno, sanitários, copa, Forro de gesso e caixilhos da fachada

Construção: sanitários, copa, forro de gesso, regularização de todas as paredes internas, revisão da cobertura existente e caixilhos da fachada

Instalação: ar condicionado, proteção e combate a incêndio

Pintura: toda edificação externamente e internamente,

Projetos: Arquitetura, Instalações elétricas e hidráulicas, Luminotécnica, Ar condicionado e Proteção e Combate a incêndio

Prazo da Obra: 60 dias

Valor: R\$2.591.228,31

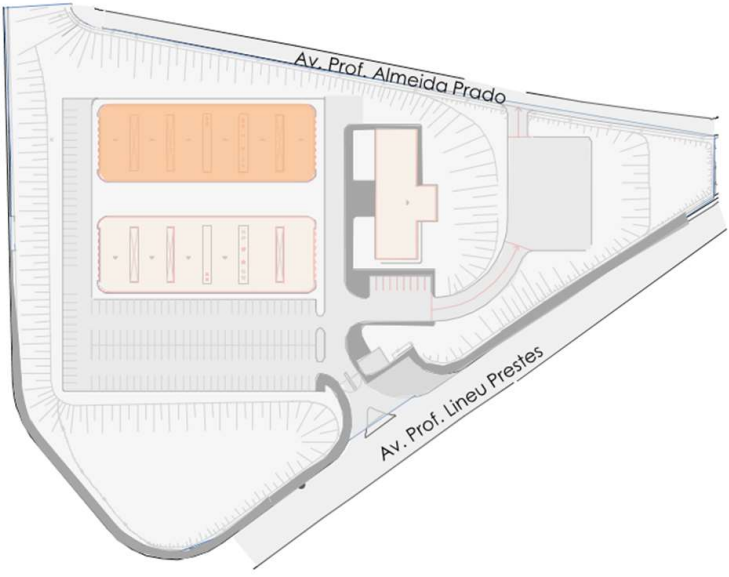




\section{Módulo Administrativo}

ITENS CONSIDERADOS NO ORÇAMENTO

Construção do prédio administrativo: $1.300 \mathrm{~m}^{2}$

Projetos: Arquitetura, Estrutura, Fundação, Instalações létricas e hidráulicas, Luminotécnica, Ar condicionado e Proteção e Combate a incêndio

Prazo da Obra: 105 dias

Valor: $\mathrm{R} \$ 4.043 .884,18$

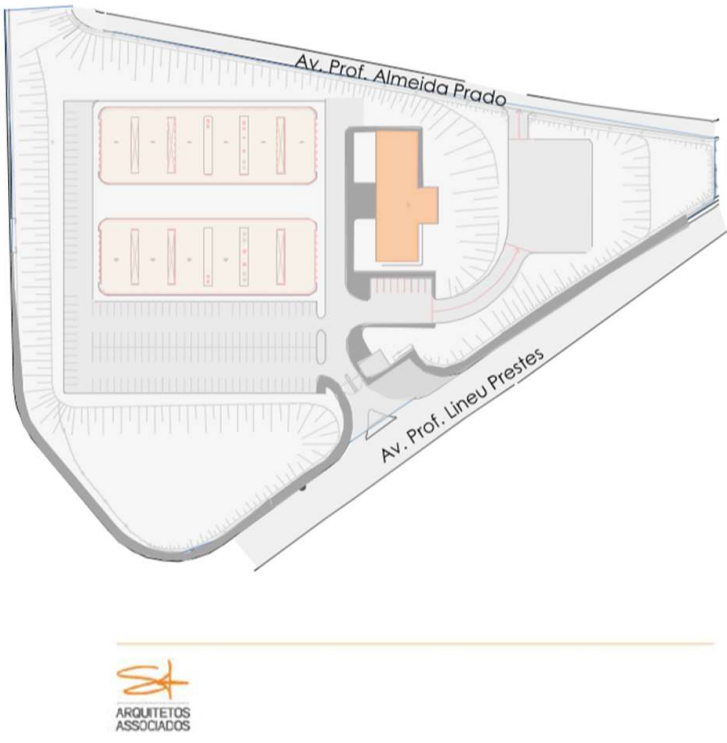

\section{Canteiro de Obras}

CONSTRUÇÃO DO CANTEIRO DE OBRAS Área: $95 \mathrm{~m}^{2}$
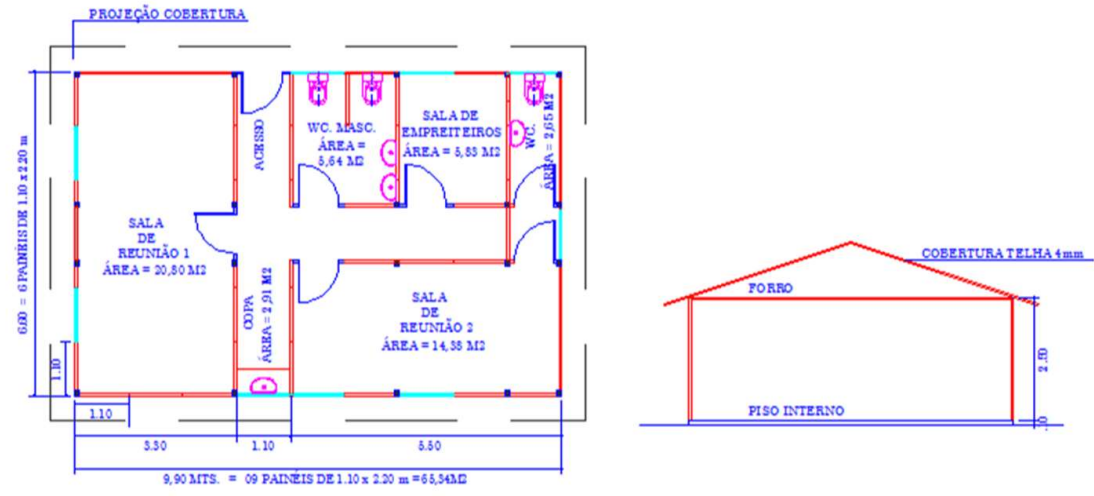

PLANTA CANTEIRO DE OBRAS

CORTE GERAL ESC. 1:100

\section{Obs: Imagens de propriedade da ST Arquitetos Associados.}


7.1 - Valoração das Demandas de Obras

\begin{tabular}{l|cc}
\multicolumn{1}{c|}{ Item } & Área & Valor da Obra \\
\hline Módulo Oeste & $1.880 \mathrm{~m} 2$ & $\mathrm{R} \$ 2.755 .830,34$ \\
\hline Módulo Leste & $1.880 \mathrm{~m} 2$ & $\mathbf{R} \$ 2.591 .228,31$ \\
\hline Módulo Administrativo & $1.300 \mathrm{~m} 2$ & $\mathbf{R} \$ 4.043 .884,18$ \\
\hline Área Externa & $27.480 \mathrm{~m} 2$ & $\mathbf{R} \$ 4.971 .519,40$ \\
\hline Valor Total & & $\mathrm{R} \$ 14.362 .462,23$ \\
\end{tabular}

7.2 - Valoração de Equipamentos e Serviços Técnicos

\begin{tabular}{|c|c|}
\hline Item & Valor \\
\hline $\begin{array}{l}\text { Equipamentos de } \\
\text { Telefonia }\end{array}$ & $\mathbf{R} \$ 250.000,00$ \\
\hline Equipamentos de TI & R\$ 300.000,00 \\
\hline Mobilia de Escritório & R\$ 500.000,00 \\
\hline Ambientação & R\$ 350.000,00 \\
\hline Total* & R\$ $1.450 .000,00$ \\
\hline
\end{tabular}

* Valores Estimados 


\subsection{Consultoria para Lançamento do Projeto}

\subsubsection{Planejamento estratégico}

Definição do escopo de atuação do NPT, incluindo o desenvolvimento dos planos estratégico e operacional para um período de 05 anos. As atividades desta etapas são:

\section{- Levantamento de Mercado e Diagnóstico de Competências}

Estudo de mercado com foco no levantamento das necessidades dos setores público e privado quanto à colaboração para inovação com institutos públicos de $\mathrm{P} \& \mathrm{D}, \mathrm{I}$ e análise do conjunto de recursos disponíveis, para financiar a estratégia de inovação do NPT.

Diagnóstico das competências do NPT com foco no atendimento das demandas existentes e futuras do mercado para projetos de inovação colaborativa.

Atividades relacionadas: Levantamento de dados em bases públicas e proprietárias; revisão de documentos contendo o histórico de atividades de P,D\&I; entrevistas com os stakeholders NPT para estruturação de matriz de competências; entrevistas com representantes de mercado para mapeamento de demandas; produção e entrega do estudo de mercado e matriz de competências NPT.

- Workshops de modelagem de negócios e mapeamento estratégico

Facilitação de 03 workshops colaborativos com equipes mistas (só NPT; NPT e parceiros; NPT e empresas), para definição dos seguintes itens estratégicos:

Proposta de Valor - Definição da Proposta de Valor do Centro de Inovação NPT, com posterior construção da missão, visão e valores da iniciativa.

Modelo de negócios - Definição das atividades de inovação a serem rentabilizadas pelo NPT; potenciais clientes e parceiros; linhas de custos e receitas a serem consideradas para construção do estudo de viabilidade econômico e financeira (EVEF).

Mapa estratégico - Construção da estratégia de criação de valor do NPT em conjunto com a definição dos benchmarks de performance, que suportarão o desenvolvimento do plano tático e a operacionalização do centro com base em indicadores estruturados.

Atividades relacionadas: definição das pessoas e papéis integrantes do Core Team que conduzirá o processo de planejamento; facilitação dos workshops colaborativos; produção e entrega dos relatórios de "achados" dos workshops;

\section{- Modelos de Governança e Organizacional}


Estruturação dos Modelos de Governança e Organizacional do NPT, definição de pessoas \& cargos, processos de gestão e sistemas necessários para execução dos referidos processos.

Atividades relacionadas: Facilitação de workshop para modelagem de governança; produção e entrega do modelo de governança; construção do organograma funcional sugerido e competências necessárias para sua operacionalização; Produção e entrega da matriz de pessoas $x$ processos $x$ sistemas necessários à operacionalização do Centro de Inovação NPT.

\section{- Estudo de Viabilidade Econômica e Financeira}

Desenvolvimento do estudo de viabilidade econômica e financeira do centro, consolidando os "achados" anteriores em um estudo de projeção dos custos e receitas previstas para o projeto ao longos dos cinco anos posteriores ao início da operacionalização da iniciativa.

Atividades relacionadas: construção e entrega das planilhas do EVEF.

\section{- Consolidação dos Planos Estratégico e Tático}

Consolidação dos planos estratégico e tático - desenvolvidos nas etapas anteriores - em um único documento, contendo a estratégia macro da inciativa e o plano de ação para sua consecução, em conjunto com os indicadores de performance - operacionais e financeiros - a serem acompanhados ao longo da sua implementação e desenvolvimento.

Atividades relacionadas: Construção e entrega dos planos estratégico e tático do projeto.

\subsubsection{Revisão do Arcabouço Institucional}

Serviço a ser conduzido pelo time jurídico da consultoria com o objetivo de ajudar o NPT na definição do modelo institucional ótimo para a melhor operacionalização da inciativa do Centro de Inovação NPT.

Atividades relacionadas: Entrevistas com o time jurídico do NPT para definição dos objetivos legais do projeto e entendimento do histórico institucional da instituição; Análise da documentação jurídica do NPT; levantamento e análise do arcabouço regulatório de inovação brasileiro pertinente ao projeto; produção e entrega do relatório e recomendação para estruturação do melhor modelo institucional para o Centro de Inovação NPT.

\subsubsection{Pacote de Marketing Promocional*}

Considerando a necessidade de captação de recursos do NPT para financiamento do projeto, um pacote básico de materiais promocionais deverá ser desenvolvido para que apoiem as ações de captação de investidores para o projeto. Estão inclusos nessa proposta, os seguintes produtos/serviços: 
- Construção de logo e pacote de comunicação visual do Centro de Inovação NPT

- Design e construção do website institucional do Centro de Inovação NPT

- Design e construção de até 02 apresentações (PPTs) - comercial e institucional

- Construção de 01 peça gráfica institucional

- Construção de até 03 newsletters eletrônicas para divulgação do projeto

- Planejamento de 01 evento para lançamento da iniciativa

\subsubsection{Cronograma Macro}

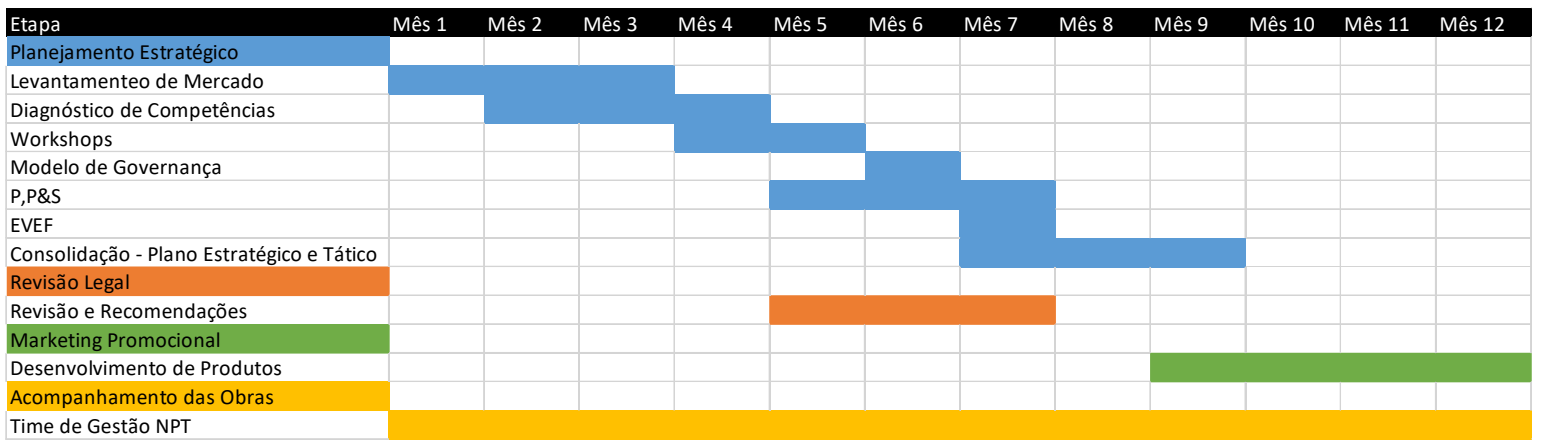

\begin{tabular}{|c|c|}
\hline Item & Valor \\
\hline Planejamento Estratégico & R\$ 300.000,00 \\
\hline Revisão Legal & R\$ 50.000,00 \\
\hline Marketing Promocional & R\$ 300.000,00 \\
\hline Equipe NPT & R\$1.050.000,00 \\
\hline Total* & $\mathrm{R} \$ 1.700 .000,00$ \\
\hline
\end{tabular}

* Valores Estimados 